\title{
Elementary Principals as Reading Instructional Leaders in Selected West Virginia Schools
}

Robin J. Lewis

West Virginia University

Follow this and additional works at: https://researchrepository.wvu.edu/etd

\section{Recommended Citation}

Lewis, Robin J., "Elementary Principals as Reading Instructional Leaders in Selected West Virginia Schools" (2011). Graduate Theses, Dissertations, and Problem Reports. 3030.

https://researchrepository.wvu.edu/etd/3030

This Dissertation is protected by copyright and/or related rights. It has been brought to you by the The Research Repository @ WVU with permission from the rights-holder(s). You are free to use this Dissertation in any way that is permitted by the copyright and related rights legislation that applies to your use. For other uses you must obtain permission from the rights-holder(s) directly, unless additional rights are indicated by a Creative Commons license in the record and/ or on the work itself. This Dissertation has been accepted for inclusion in WVU Graduate Theses, Dissertations, and Problem Reports collection by an authorized administrator of The Research Repository @ WVU.

For more information, please contact researchrepository@mail.wvu.edu. 
Elementary Principals as Reading Instructional Leaders in Selected West Virginia Schools

\author{
Robin J. Lewis
Dissertation submitted to the
College of Human Resources \& Education
at West Virginia University
In partial fulfillment of the requirements
for the degree of \\ Robin J. Lewis
Dissertation submitted to the
College of Human Resources \& Education
at West Virginia University
In partial fulfillment of the requirements
for the degree of \\ Doctor of Educational \\ In \\ Educational Leadership Studies
}
Helen Hazi, Ph. D., Chair
Paul Chapman, Ph. D.
Steven Paine, Ed. D.
Ted Price, Ph. D
Richard Walls, Ph. D.

Department of Educational Leadership Studies

Morgantown, West Virginia

2011

Key Words: Leadership, Principals, Reading, Reading First, Student Achievement 


\begin{abstract}
Elementary Principals as Reading Instructional leaders in Selected West Virginia Schools
\end{abstract}

Robin J. Lewis

This study examined the reading instructional leadership practices of 56 principals in West Virginia K-5 public elementary schools. The purpose of this study was to compare the reading instructional leadership practices and professional development of 40 Reading First principals with 40 non-Reading First principals in West Virginia. The study also compared the percentage of students who have scored mastery or above as measured by the third grade Reading/Language Arts West Virginia Educational Standards Test (WESTEST) in the years 2005, 2006, and 2007. An electronic survey with Likert-type items was distributed to all 40 Reading First Principals and $303 \mathrm{~K}-5$ public elementary principals in West Virginia. There was a $70 \%$ response rate from the Reading First Principals. The survey was a self-reporting, web-based survey, developed utilizing Survey Monkey. Study results reveal that reading First Principals were better Resource Providers than non-Reading First Principals. Additionally, Reading First Principals support reading professional development activities for teachers at the school level at a statistically significantly higher rate than did the non-Reading First. Finally, there was no statically significantly impact on student achievement as measured by standardized test scores in the Reading First Schools. 


\section{DEDICATION}

This work is dedicated to my family, Shannon Kristine, Amy Marie, Rebekah Joy and Lenny Lewis. You have made my days brighter and my heart warmer. I also dedicate this work to my parents, Roy and Joy Bennett and my sister Susan, who modeled early for me the importance of education, hard work, and commitment. I truly appreciate your endless support and guidance. I love all of you dearly. 


\section{ACKNOWLEDGEMENTS}

Completion of this doctoral program was a grueling journey and I would like to show my gratitude to the following individuals who have helped guided and supported me along the way. Without their assistance, this study could not have been completed: Dr. Helen Hazi, Dr. Richard Walls, Dr. Paul Chapman, Dr. Steven Paine, Ted Price and Dr. Mary Lee Porter. A special thanks to my chairperson, Dr. Helen Hazi whose expectations have made me a better writer and intellectual. I am truly grateful for Dr. Hazi endurance and guidance. I would also like to offer a special thanks to Dr. Richard Walls for his assistance with my understanding of research statistics. Thank you, Larry White, for helping me with the statistical analyses of the data.

I appreciate the assistance and support of my friends and colleagues in the Hampshire County school system, particularly, Susan Alkire, Denise Hott and Lorrenda Roeder who have incredible computer skills.

Finally, I am deeply grateful to Dr. Sara Stankus and my Cohort friends who have accompanied me along my journey and were a constant source of encouragement. 


\section{TABLE OF CONTENTS}

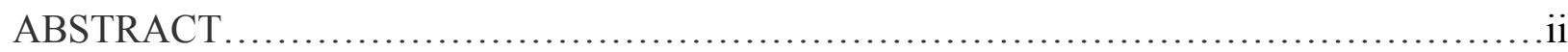

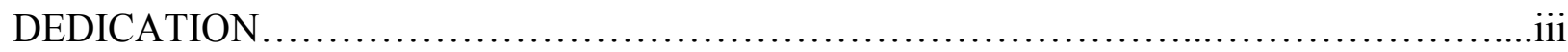

ACKNOWLEGEMENT ......................................................................

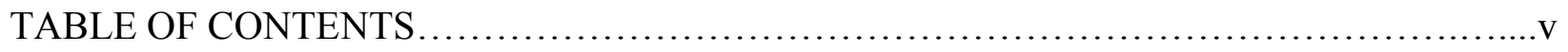

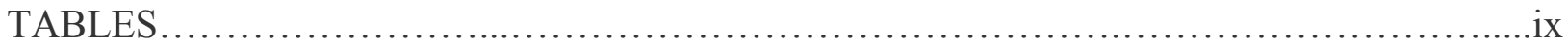

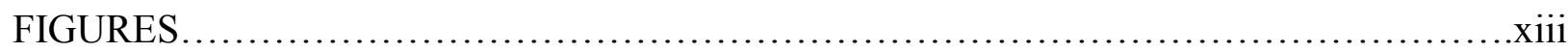

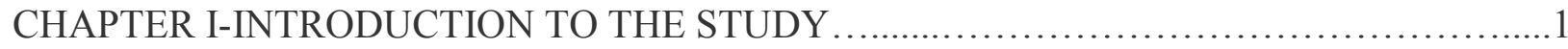

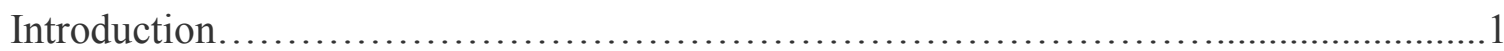

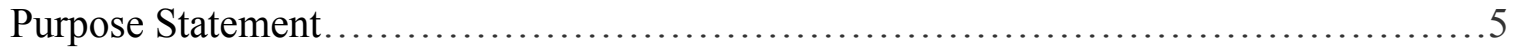

Research Questions..................................................................

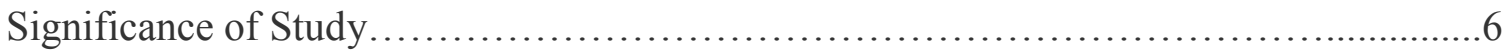

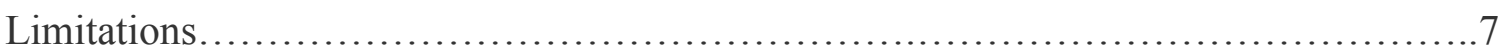

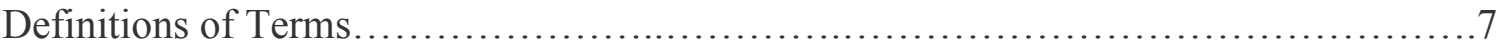

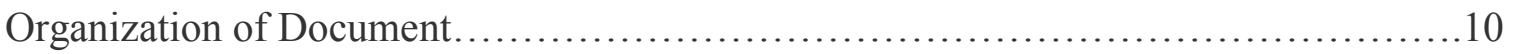

CHAPTER II-LITERATURE REVIEW................................................

Leadership .................................................................. 11

School Effectiveness Research....................................................

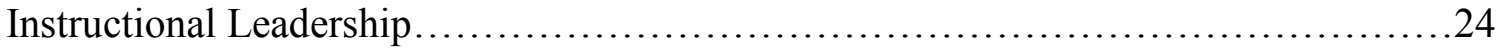

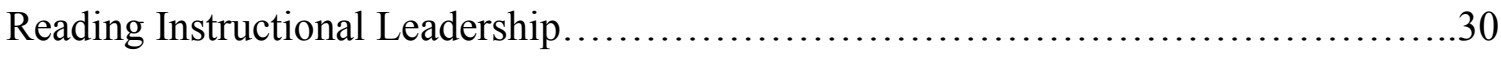

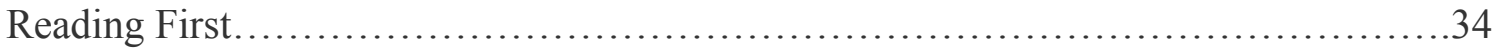

Electronic Dissertation Analysis..............................................41

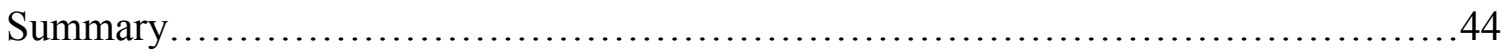




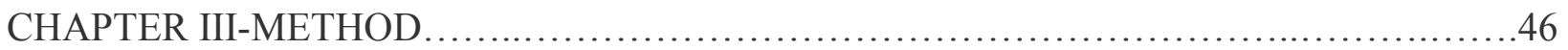

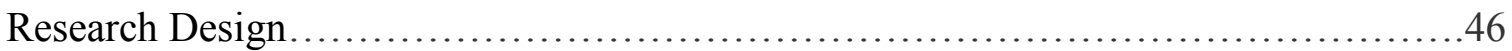

Research Participants.......................................................48

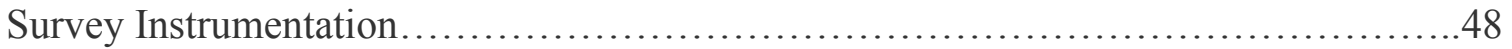

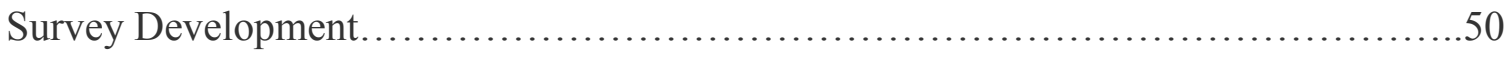

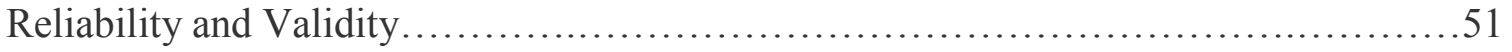

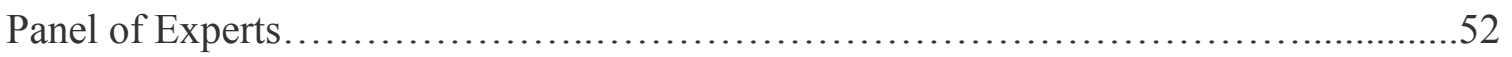

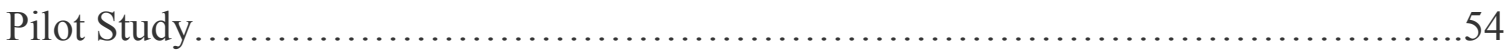

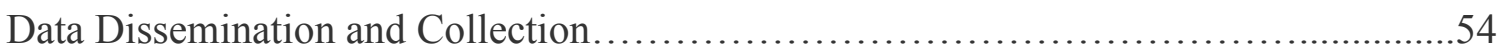

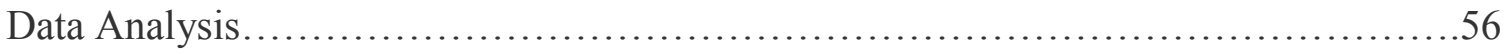

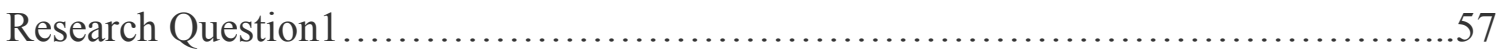

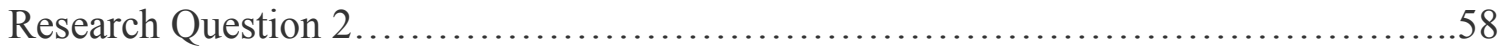

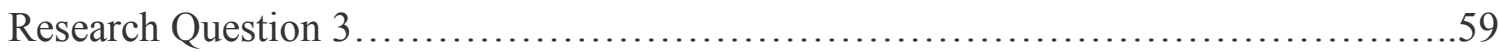

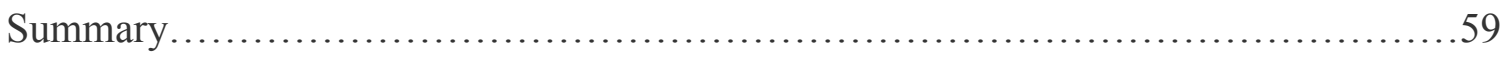

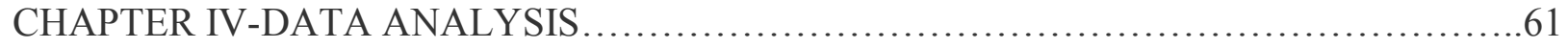

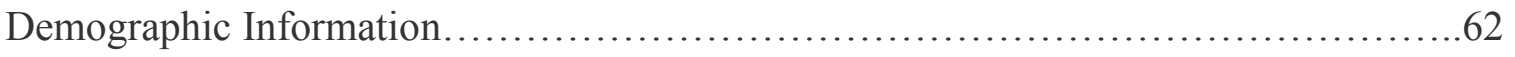

Research Questions..........................................................66

Research Question 1........................................................66

Provider Principal as Resource ...................................................66

Principal Interaction with Teachers................................................ 71

Principal Assurance of School Climate Conductive to Literacy Development............78

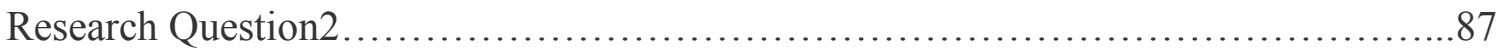

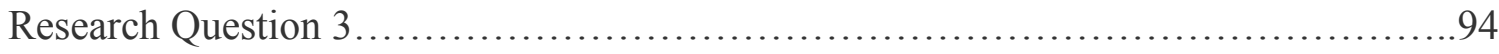


Research Question 3 Part 1: ALL Students....................................95

Research Question 3 Part 2: low SES ............................................99

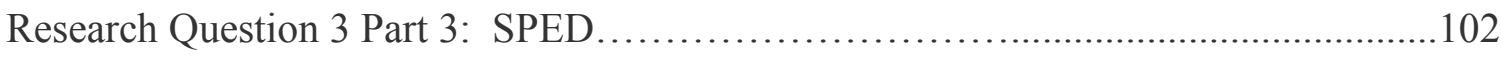

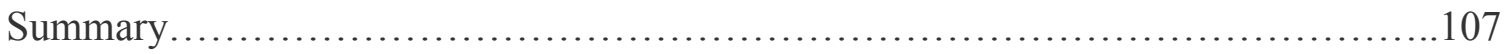

CHAPTER V-SUMMARY, CONCLUSION, DISCUSSION AND RECOMMENDATIONS.110

Summary ............................................................. 110

Research Questions.......................................................111

Conclusion.................................................................... 118

Discussion.................................................................... 118

Recommendations for Practice............................................ 121

Recommendations for Research............................................. 123

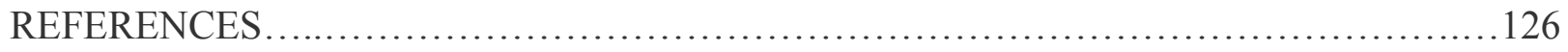

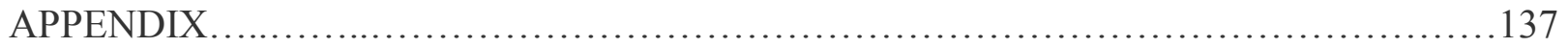

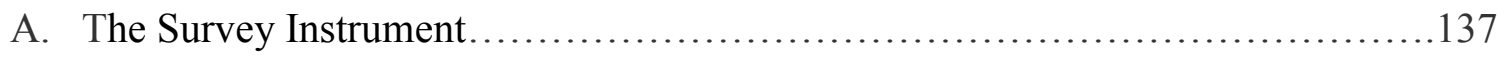

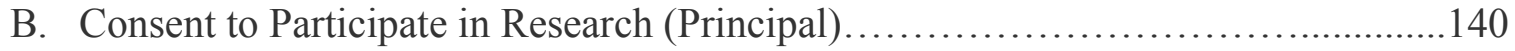

C. Chart showing domains parallel with IRS standards..........................141

D. Standards for International Reading Association............................. 142

E. Directions for Panel of Experts......................................... 167

F. Superintendent Survey Notified Letter.........................................168

G. Pilot Survey Letter-Invitation....................................... 169

H. Panel of Experts-Questions.............................................. 170

I. Original Reading First Counties-State Map.................................171

J. Timeline.............................................................. 172 
K Porter Letter............................................................ 174

L Panel of Expert Feedback.................................................. 175 


\section{TABLES}

Table 1 Leadership Responsibilities............................................17

Table 2 Variable Involved in the Analyses..........................................5

Table 3 Demographic Information for Reading First and non-Reading First Principal.........64

Table 4 Question 1: Provides funding to build classroom libraries.........................67

Table 5 Question 2: Provides resources for Tier II and Tier III Interventions...............67

Table 6 Question 3: Facilitates professional development for teachers....................68

Table 7 Question 4: Provides opportunities for teachers to attend conferences and trainings........................................................ 68

Table 8 Question 5: Provides on-going follow-up training/professional development........69

Table 9 Question 6: Facilitates standardized test data analysis with teachers................69

Table 10 Principal as Resource Provider (Items 1-6)................................ 70

Table 11 Principal as Resource Provider, High/Low Response (Items 1-6)..................71

Table 12 Question 7: Shares information with faculty to keep them aware of what is

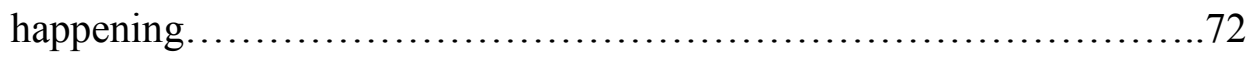

Table 13 Question 8: Participates in analysis of reading assessment/data/instructional

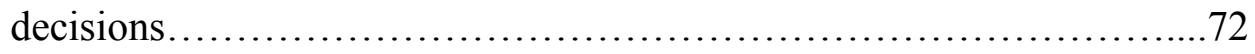

Table 14 Question 9: Interacts informally regarding curriculum and instruction...............73

Table 15 Question 10: Checks lesson plans and provides feedback regarding reading instruction.

Table 16 Question 11: Uses observation walk-through for reading to ensure reading instruction is occurring in all classrooms at grade levels..............74

Table 17 Question 12: Participates in interviewing and hiring of new teachers.... .74 
Table 18 Question 14: Listens to children read frequently (time is spent on weekly basis listening to children read) ....................................

Table 19 Question 15: Reads to students frequently (time is spent on a weekly basis

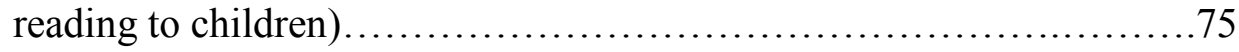

Table 20 Question 16: Interacts informally with students.............................. 76

Table 21 Question 17: Provides opportunities for celebration in forms of prizes, awards, or stunts................................................ 76

Table 22 Principal Interaction with Teachers (Items 7-17)............................... 77

Table 23 Principal Interactions with Teachers, Low/High (Items 7-17)...................78

Table 24 Question 18: Protects the 90/120 minute reading block.........................79

Table 25 Question 19: Supports special activities that focus on instructional goals tested

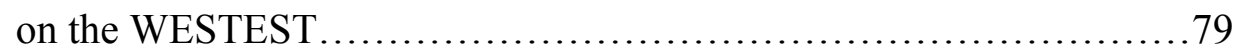

Table 26 Question 20: Supports reading/literature courses for students in all grades..........80

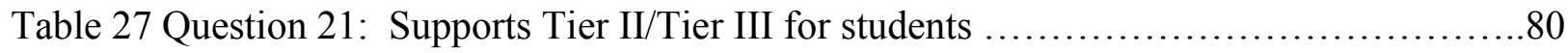

Table 28 Question 22: Supports peer/parent tutoring programs........................... 81

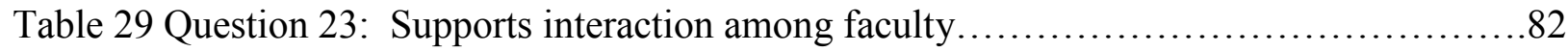

Table 30 Question 24: Supports displays of student work in classrooms and halls............82

Table 31 Question 25: Supports voluntary reading by students upon task completion..........83

Table 32 Question 26: Supports reading to students by guests/parents....................83

Table 33 Question 27: Assures school/classroom incentive programs for reading.............84

Table 34 Principal Assurance of School Climate Conductive to Literacy Development

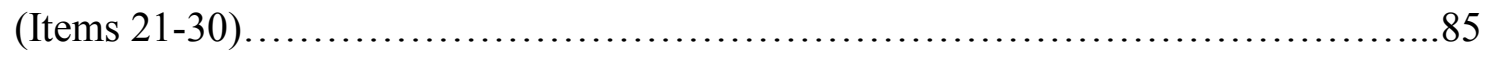


Table 35 Principal Assurance of School Climate Conductive to Literacy Development Low/High Response (Items 18-27) .................................... 86

Table 36 Question 28: Undergraduate courses in reading.............................. 87

Table 37 Question 29: If yes, did they help (see note) $\ldots \ldots \ldots \ldots \ldots \ldots \ldots \ldots \ldots \ldots \ldots \ldots \ldots \ldots$

Table 38 Question 30: Graduate courses in reading you took, if any........................88

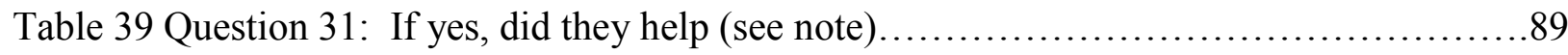

Table 40 Question 32: Professional reading of journal/articles pertaining to reading research and instruction..........................................89

Table 41 Question 33: Professional development for Reading First schools at the school level................................................... 90

Table 42 Question 34: Training from WVDE pertaining to Reading First.....................90

Table 43 Question 35: RESA level training in the area of reading.......................91

Table 44 Question 36: Reading content presented during Principal Academy................91

Table 45 Question 37: Experiences during teaching................................. 92

Table 46 Question 38: Experiences during principal ship.............................92

Table 47 Question 39: Interactions with teachers/reading specialists....................93

Table 48 Frequency of Responses of Principal Professional Development (Items

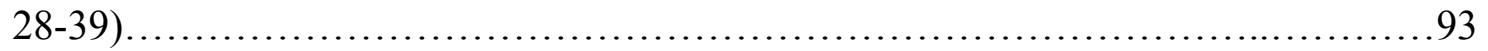

Table 49 Reading/Language Arts ALL Descriptive Statistics - Mean Scale Scores and Standard Deviations............................................... 95

Table 50 Reading/ Language Arts ALL Students Test of Between-Subject Effects.............97 
Table 51 Reading/Language Arts, ALL Students Multiple Comparisons among the Six Means. .98

Table 52 Reading/Language Arts low SES Subgroup Descriptive Statistics of Mean Scale

Scores and Standard Deviations.............................................. 99

Table 53 Reading/Language Arts low SES Subgroup Test of Between-Subject Effects........101

Table 54 Reading/Language Arts, low SES subgroup Multiple Comparisons among the Six

Means.

Table 55 Reading/Language Art Disabilities Subgroup (SPED) Descriptive

Statistics Mean Scale Scores and Standard Deviations. 103

Table 56 Reading/ Language Arts SPED Subgroup Test Between-Subject Effects..... 105

Table 57 Reading/Language Arts, SPED subgroup Multiple Comparisons among the Six

Means 


\section{FIGURES}

Figure 1 WESTEST Reading/Language Arts in ALL Student Mean Scale Scores

Reading First and non-Reading First Schools 2005 to $2007 \ldots \ldots \ldots \ldots \ldots \ldots \ldots \ldots \ldots$

Figure 2 WESTEST Reading/Language Arts low SES Subgroup Mean Scores for

Reading First and non-Reading First schools from 2005 to $2007 \ldots \ldots \ldots \ldots \ldots \ldots \ldots$

Figure 3 WESTEST Reading/Language Arts SPED Subgroup Mean Scales Scores

Reading First and non-Reading First Schools from 2005 to $2007 \ldots \ldots \ldots \ldots \ldots \ldots \ldots 104$ 


\section{CHAPTER I INTRODUCTION}

The purpose of Reading First was to -ensure that all children in America learn to read well by the end of the third grade, utilizing quality interventions matched to student needs, coupled with formative evaluation to obtain data over time to make critical educational decisions" (National Association of State Directors of Special Education, 2005, p.1). Reading First provided assistance to states and districts to establish scientifically-based reading programs. Supporting funds increased professional development to ensure that all teachers had the skills

they needed to teach these programs effectively. Reading First also supported the use of screening and diagnostic tools and classroom-based instructional reading assessments to measure how well students were reading and to monitor their progress.

Mandates outlined in Reading First, part of No Child Left Behind, have changed the role of administrators. Principals must now juggle the demands of management, become leaders of change, and act as literacy instructional leaders. According to Lashway (2002), principals also need to align staff development with student learning needs. Administrators are challenged to make every child a reader by the third grade. Traditionally, principals have acted as school managers. Today, however, they need additional expertise to make a serious impact on literacy in their schools.

In 2002 The United States Congress appropriated \$900 million to the Reading First program for the 2002 Fiscal Year (FY). This funding would continue for six years and conclude in FY 2009. Initiated under the mandates of No Child Left Behind, the Reading First program focused on implementing scientific-based methods of early reading instruction in classrooms. Through Reading First, states and districts received support to apply scientifically-based reading research and proven instructional and assessment tools to ensure that all children would learn to 
read by the end of third grade. The program provided formula grants to states that submitted an approved application. State Education Administrations (SEAs) awarded subgrants to eligible Local Education Associations (LEAs) on a competitive basis. SEAs funded those proposals that demonstrated the most promise for successful implementation of reading instruction, particularly at the classroom level, in order to raise student achievement. Only these programs founded on scientifically-based reading research were eligible for funding through Reading First. Funds were allocated to states according to the proportion of children aged 5 to 17 who resided within the state and who were from families with incomes below the poverty level (United States Department of Education, 2008).

When President George W. Bush began his term in office in January 2001, one of his top priorities was improving public school education. As a result, in January 2002, No Child Left Behind was introduced as legislation and signed into law. This act created stricter test-motivated accountability in public schools and was geared toward encouraging greater attention to lowachieving students and low-performing schools. Michael Petrilli (Finn, Petrilli, \& Julian, 2006) of the Thomas B. Fordham Foundation, which advocates school choice in relation to No Child Left Behind, believes that people needed to understand that No Child Left Behind has three main objectives: close the achievement gap, help school systems overcome challenges associated with economic disadvantage, and provide external incentive for internal change.

Prior to No Child Left Behind, the report of the National Reading Panel (United States Department of Health and Human Services, 2000) had issued a report that responded to a Congressional mandate to help parents, teachers, and policy makers identify key skills and methods central to reading achievement. Consequently, federally funded, scientific-based 
reading research programs were mandated in order to assure administrators and teachers worked together to improve reading achievement for all students.

In order to receive Reading First grant funding, states were required to submit a plan to improve academic achievement of economically disadvantaged children, giving special attention to reading. Upon approval, state funding was appropriated based on the state's proportion of school-aged children from families with an income below the poverty level (United States Department of Education, 2002). Through this initiative, Reading First schools were identified as low-achieving schools. They were selected based on their eligibility as a Title 1 School, low reading test scores $\left(25 \%\right.$ or more students below the $35^{\text {th }}$ percentile on SAT 9 grade 3 reading), and agreement to have all professional staff attend one hundred hours per year for six years of staff development. This staff development consisted of -intensive sustained, research-based professional development opportunities in reading instruction and assessment practices" (United States Department of Education, 2002, p.1).

On July 21, 2003 U.S. Secretary of Education Rodney Paige announced that West Virginia would receive approximately $\$ 43.8$ million dollars over the next six years to administer the Reading First Program. Through this incentive, eligible counties received funding to design reading instruction in the elementary grades based on scientific research and professional development of principals and staff Reading First included an intense one hundred hours per year of professional development, use of assessment data to drive instruction, and a core scientific-based reading instructional program (United States Department of Education, 2002).

The one hundred hours per year of professional development was high-quality training for developing teachers` knowledge and skills as they related to the goals of Reading First, including scientifically-based reading research, assessment issues, effective instructional 
strategies of a core reading program, and intervention concerns. In an effort to improve reading skills of students kindergarten through third grade, heightened attention required reading interventions necessary to prevent reading failure among our nation's children. Among the funded requirements were materials, access to print, management teams, and evaluation. Reading First approved counties in West Virginia included: Calhoun, Doddridge, Fayette, Gilmer, Hampshire, Hardy, Kanawha, Lincoln, Logan, Mason, McDowell, Mercer, Mineral, Mingo, Monongalia, Nicholas, Pocahontas, Preston, Roane, Summers, Tucker, Upshur, Webster, Wetzel, and Wirt. These represent almost one-half of the 55 county school systems.

Because No Child Left Behind was law, educational administrators in states accepting Reading First funding focused on the work of teaching and learning. Consequently, principals“ roles have changed from that of traditional managers to that of instructional leaders. The paradigm shift has put many administrators in the position of a change agent (Fullan, 2001). Reading instructional leadership required administrators to have a basic knowledge of the components required for successful reading instruction. The required five key components for all state Reading First programs included: phonemic awareness, phonics, fluency, vocabulary, and comprehension. In addition, Reading First required professional development for teachers, and to ensure accountability through valid and reliable screening, diagnostics, and classroombased assessments (United States Department of Education, 2002). Reading First also allowed for the use of supplemental and intervention programs for Tier II and Tier III. Administrators identified appropriate times and tools to use when assisting teachers in the endeavor of helping children to become fluent readers by third grade (Beck, 2006). 


\section{Purpose Statement}

The purpose of this study was to compare the reading instructional leadership practices and professional development of 40 Reading First principals with 40 non-Reading First principals. There were 40 Reading First West Virginia K-5 public elementary principals, leaving 303 from which to select 40 non-Reading First West Virginia K-5 public elementary principals by a random sample. The study also compared the percentage of students who scored mastery or above as measured by the third grade Reading/Language Arts West Virginia Educational Standards Test (WESTEST) in the years 2005, 2006, and 2007. These years were specifically chosen based on the initiation of the new WESTEST 2 during the 2008-2009 school years. The 2008 WESTEST scores were also omitted due to the commencement of the West Virginia policy 2510, which required all elementary schools to implement the Three-Tier Reading Model, a more structured approach to reading instruction.

\section{Research Questions}

The overall research compared the differences between Reading First and non-Reading First, principals‘ professional development, reading instructional leadership practices, and the students' Reading/Language Art test scores as measured by the WESTEST during 2005, 2006, and 2007 from each group. The WESTEST was the educational achievement test used during that time period. The performance levels from highest to lowest were: distinguished, above mastery, mastery, partial mastery, and novice. The WESTEST was administered to students in grades 3-8 in the subject areas of Math, Science, Social Studies, and Reading/Language Arts.

This study determined whether there were statistically significant differences between the variables. The study also examined the means of the principals' demographic data: gender, years 
spent teaching reading, number of reading courses taken, years as principal in what grade level, and hours spent on instructional issues.

The population of elementary principals was 343 in West Virginia K-5 public schools. To ensure equality, 40 Reading First and 40 non-Reading First Schools were selected for a total of 80 principals.

In order to determine if there were a relationship between levels of principal professional development and student achievement this dissertation study considered the following research questions:

\section{Research Question 1}

Do the reading-instructional-leadership practices of principals differ in Reading First Schools versus non-Reading First Schools?

\section{Research Question 2}

Does the reading-instructional-leadership professional development of principals differ in Reading First Schools versus non-Reading First Schools?

\section{Research Question 3}

Is there a difference in Reading/Language Arts WESTEST scores for the years 2005, 2006, and 2007 for third grade students in Reading First versus non-Reading First Schools?

\section{Significance of the Study}

This study presents results that can be of value to both current and prospective practitioners. If a relationship existed between principals‘ level of professional development and student achievement, then state and county administrators, as well as those who develop policy, could modify their own administrative behavior to promote reading instructional leadership at local school levels. 
Second, the result of this research has implications for school administrator preparation programs. According to West Virginia Policy 5500.03, every principal is expected to participate in the Principal's Academy at least every four years. Principals should take professional development in reading to update their expertise. The results of this study impact continuing education (CE) programs that were presented to new and experienced principals. Changes in education during the twenty-first century required building-level principals to become instructional leaders.

Third, this is the first completed study regarding the levels of public K-5 West Virginia Reading First and non-Reading First principal professional development and the potential impact on student achievement in the state of West Virginia.

\section{Limitations}

According to Survey Monkey, email addresses may possibly block receipt of any information from them if that person has established a preference of electronic blocking. Another possible limitation may include the random selection of non Reading First principals and their schools' data without control variables. This research study did not consider the percentage of low SES, special education students, or total student population in the selection of the non-Reading First schools. The limitation of using random selection without control variables was due to the number of schools in the non-Reading group.

\section{Definitions of Terms}

Effective Schools: Lezotte and McKee (2002) conceive an effective school is a school that can, in deliberate student achievement terms, show the combined attention to quality and equity. Leadership provided by a principal must establish a school climate conducive to high levels of student achievement, promote teaching and learning, establish a clear and concise school vision and mission statement, establish high levels of parent involvement, and frequently monitor results in order to continuously improve. 
Five Components of Reading: The report on the National Reading Panel (United States Department of Health and Human Services, 2000) and No Child Left Behind summarized several decades of scientific research that clearly showed effective reading instruction addresses five critical areas: phonemic awareness, phonics, fluency, vocabulary, and comprehension.

Instructional Leadership: Described as the process of social influence in which one person can enlist the aid and support of others in the accomplishment of a common task (Chemers, 2002).

No Child Left Behind Act: The No Child Left Behind Act of 2001 passed both houses of Congress with overwhelming bipartisan support. It was enacted on January 8, 2002 with the goal of having every child reading and doing math at grade level by 2014. The major principles of the act include: stronger accountability for results, proven education methods, and more choices for parents. The effects involve K-12 public schools, particularly those receiving Title I funds due to high-poverty populations (United States Department of Education, 2002).

Reading First Principal: Reading First Principals are those elementary principals based in a K-5 public school who received funding for Reading First.

Reading First Program: Reading First is a federal program which focuses on improving reading instruction for teachers of K-3 students to ensure all children can read at or above grade level by the end of third grade. Emphasis is placed on providing reading teachers in grades K-3 with intensive, sustained, research-based professional development opportunities in reading instruction and assessment practices. Reading First is a requirement of the No Child Left Behind Act of 2001 as outlined in Title I, Part B of the legislation.

Reading Instructional Leadership: Reading Instructional Leadership is a deeper involvement in the core business of schooling which is teaching and learning. Instructional 
leadership is leading learning communities (DuFour, 2002). Specific behaviors include: making suggestions, giving feedback, modeling effective instruction, soliciting opinions, supporting collaboration, and providing professional development opportunities (Blasé \& Blasé, 2000).

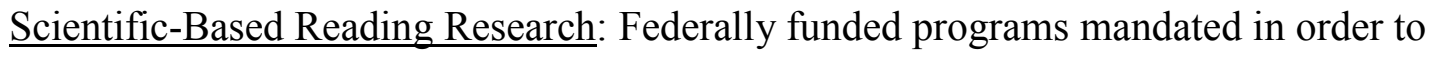
ensure administrators and teachers work together to improve reading achievement for all students.

Title I Schools: Annual federal financial assistance which is provided to schools with high percentages of poverty for the purpose of providing supplemental resources such as funding to support additional reading specialists and professional development opportunities to assist atrisk students in meeting state standards, especially in reading and mathematics. Local education agencies allocate Title I funds to public schools with the highest percentages of children from low-income families based on student free or reduced meals.

WESTEST: The WESTEST was an educational achievement test that was used in West Virginia in 2005, 2006, and 2007 school years. The performance levels were, from highest to lowest: distinguished, above mastery, mastery, partial mastery, and novice. A student who achieves a score below mastery in one or more subject areas is not required to repeat the grade. The WESTEST was administered to students in grades 3-8 in the subject areas of math, science, social studies, and reading/language arts. The reading/ language arts scores of third graders in selected schools are used in this study. 


\section{Organization of Document}

This dissertation includes five chapters beginning with the study's introduction and research justification. Chapter I provides a brief introduction of the topic, which included background information regarding No Child Left Behind legislation. The introduction also presented the scope of the study. The problem statement was introduced, along with the purpose, the three research questions, the significance, and the definitions of terms.

Chapter II presents a review of related literature dealing with evolving trends in the practices and procedures regarding the Reading First program from a national and state perspective. This chapter presents research relating to leadership, school effectiveness, reading instructional leadership practices, scientifically-based reading research, and the five essential components of reading.

Chapter III delineates the research design and methodology in particular, the survey instrument used to gather the data. Furthermore, the population section provides a detailed description of the study's research design including methods regarding the study's procedures and data analysis. Figures and tables illustrating demographic information are also presented.

Chapter IV presents an analysis of the data from the survey. Findings were reported by analyzing the three research questions. Figures and tables illustrate the answers to each of the research questions.

Chapter V contains conclusions, discussion, and recommendations for practice for professional development practice, for future research, and concluding remarks. 


\section{CHAPTER II LITERATURE REVIEW}

The purpose of this study was to compare the reading instructional leadership practices and professional development of 40 Reading First principals with 40 non-Reading First principals in West Virginia. There were 40 Reading First West Virginia K-5 public elementary principals, leaving 303 from which to select 40 non-Reading First West Virginia K-5 public elementary principals by a random sample. The study also compared the percentage of students who have scored mastery or above as measured by the third grade Reading/Language Arts West Virginia Educational Standards Test (WESTEST) in the years 2005, 2006, and 2007. The review of literature provides the rationale and background for the study and the questionnaire used in the study. The chapter is organized into the following sections: Leadership, School Effectiveness Research, Instructional Leadership, and Instructional Leadership in Reading, Dissertation Research, and Summary.

\section{Leadership}

The purpose of this section is to review the research of effective leadership practices. It will provide a theoretical framework for this research and a historical perspective on the principal as the instructional leader. In addition, the characteristics of effective instructional leadership practices will be examined. Much of the theory of leadership addresses the power and authority of effective leaders. However, there are limited theories identifying instructional dimensions of principals (Cuban, 1984; Hoyle, 1988). This section gives guidance on leadership that makes a difference on instruction in general, but not reading specifically.

Leadership has long been perceived to be important to the effective functioning of organizations in general and more recently, of schools (Marzano, McNulty \& Walters, 2005). Research suggests that there is a correlation between the principal's knowledge of reading and 
student achievement (Austin, 1985). Researchers have concluded that an administrator's knowledge about reading or course work in reading will have an influence on school reading achievement (Schatschneider, Foorman, \& Mehta, 1999). They have determined that principals should be involved in staff development (Doan \& Doan, 1984). Furthermore, principals should develop teaching teams, monitor student achievement, and share the vision for the school in working with the district and parents (DuFour, 2002).

Leadership is regarded as one of the primary indicators of principal success (Marzano, et al. 2005). Marzano, et al. examines the effects of school leadership on student achievement and the specific leadership practices that impact school effectiveness. This research scrutinizes school leadership principal management of schools during demanding times that accompany major change initiatives. Marzano, et al. examined leadership effectiveness in their book School Leadership That Works. Based on their meta analysis of 69 studies conducted since 1970 that met their selection criteria and a recent survey of more than 650 building principals, Marzano developed a list of 21 leadership responsibilities that have a significant impact on student achievement.

McEwan (2003) noted a number of significant dimensions of leadership, defining leadership as an interpersonal influence aimed at refining the communication process toward the achievement of goals. McEwan encouraged leaders to demonstrate courage and vision to lead teachers to achieve their highest instructional goals. In order for principals to have substantial impact on the lives of students and staff, he developed a practical, hands-on guide to assist principals in becoming effective instructional leaders. McEwen's seven steps include: establish, implement, and achieve academic standards, be an instructional resource for your staff, create a learning-oriented school culture and climate, communicate the school's vision and mission to 
staff and students, set high expectations for staff and self, develop teacher leaders, and develop and maintain positive relationships with students, staff, and parents. This research encouraged principals to integrate these seven steps into their daily leadership behaviors. McEwan's research also provides an instructional leadership checklist which can be used to: assess current level of instructional leadership, how the staff thinks the principal is doing as a leader, assist in goal setting for improving instructional leadership practice and finally, evaluate progress toward goals. According to this research, attaining a new and higher level of instructional leadership will make a difference for all school stakeholders. Staff, students, and parents will realize that all students matter and begin expecting that all students can learn. Ultimately, the school will achieve its mission to improve education (McEwan, 2003). The limitation of McEwan (2003) is that it does not address reading instructional leadership.

Other research has defined leadership as encouraging followers to strive for goals that represent the values, motivations, wants, needs, aspirations and expectations of both leaders and followers (Phillips, 1992). Hackman and Johnson (2000) stressed the importance of communicating the attitudes and behavior of others in order to meet school goals.

Lezotte (2001) concluded that followers are encouraged by goal achievement. This can only be attained if both leaders and followers are working diligently toward achieving the same goal. Lezotte provided a framework for effective school leadership for principals: building an inclusive, collaborative process; assembling an effective leadership team; identifying and clarifying the school's core beliefs and values; and ensuring that everyone's efforts are focused on the common goal of improving student performance. This research leads principals through the continuous improvement cycle, and teaches hands-on strategies needed to make judicious, effective, and lasting changes that truly impact student achievement. Lezotte emphasizes the 
importance of data collection, identification and evaluation of the leading indicators of learning based on the Correlates of Effective Schools, and identification of what constitutes a useful and usable plan and the obstacles to change.

Noddings (1991) offers gender perspectives regarding leadership effectiveness. In his research, Noddings reports that research provides considerable evidence that there is a gender bias in reading materials used in school: (1) females appear as main characters and in illustrations far less frequently than males; (2) females and males are overwhelmingly portrayed in sex-stereotypical roles; (3) females appear more often than males in derogatory roles; and/or (4) male generic language is used (p. 67). This research states that although positive changes have been made in reading texts especially in the elementary reading text, higher education texts have been slower to implement these changes. Much of the literature addressing effective schools, school reform, and school restructuring has emphasized the importance of school climate on student achievement. Bailey, (1997) reviewed teacher empowerment (Rinehart \& Short, 1994) and curriculum enrichment reflecting multicultural education (Banks, 1991). Each of these recommendations asserting to improve school climate identify the principal as a pivotal actor. Principals must play a major role in both implementing change and evaluating personnel for successful restructuring to take place (The National Commission on Excellence in Education, 1983).

Spillane (2000) classified school leadership as the identification, acquisition, allocation, coordination, and use of the social material, and cultural resources necessary to establish conditions for the possibility of innovation in teaching and learning. This research focuses on distributive leadership and the importance of distributing tasks to stakeholders. Spillane's research involving Chicago elementary schools, illustrates that the execution of most leadership 
functions and activities involve multiple leaders. Principals rarely are the sole source of the leadership roles in the school environment. This research found that leadership is distributed over multiple leaders. Distributive leadership is a framework to understand all types of leadership and management. While prior school leadership research tends to emphasize the behaviors and traits of leaders such as principals, the distributed perspective emphasizes how leadership practice is formed in the interactions among school leaders, followers, and their situations. An example of this practice would include the reading specialist working with a professional learning community to disaggregate data and make instructional decisions based on the findings. Collaborative distribution occurs when the actions of one leader become the basis for actions of another leader. An example of collaborative distribution includes grade level meetings that involve administration, specialists and classroom teachers. Collective distribution occurs when leaders act separately and independently but strive toward a shared goal. Collective distribution occurs when sequential tasks are led by different individuals.

Marzano, et al. (2005) conducted a factor analysis using the responses to a questionnaire designed to quantify principals‘ performance in terms of 21 responsibilities (Table 1). This involved a statistical procedure used to uncover relationships among many variables. This research found two underlying factors, first-order and second-order change. First-order change is incremental and is often thought of as the next logical step to take in the school or county. The change is gradual and subtle and is the next most obvious step to take and does not depart radically from the past. An example of a first-order change may include changing itinerate schedules to accommodate a new reading block or making systematic and frequent visits to the classroom. Second-order change involves a deep change, a dramatic departure from the expected and requires a new way of thinking and acting. This change involves a major departure 
from the predictable and requires new ways of thinking and acting, such as schools using student data to drive decision making in the learning environment. Another example includes the intellectual stimulation of teachers, using knowledge of research and theory or best practices among staff through reading and discussion. This practice may include professional learning communities focused on scientific based reading research.

Table 1 display the 21 responsibilities by Marzano and defines each of the responsibilities. 
Table 1

Leadership Responsibilities

\begin{tabular}{|c|c|}
\hline Responsibilities & The extent to which the principal \\
\hline Culture & $\begin{array}{l}\text { fosters shared beliefs and a sense of community and } \\
\text { cooperation }\end{array}$ \\
\hline Order & $\begin{array}{l}\text { establishes a set of standard operating procedures and } \\
\text { routines }\end{array}$ \\
\hline Discipline & $\begin{array}{l}\text { protects teachers from issues and influences that would } \\
\text { detract from their teaching time or focus }\end{array}$ \\
\hline Resources & $\begin{array}{l}\text { provides teachers with materials and professional } \\
\text { development necessary for the successful execution of } \\
\text { their jobs }\end{array}$ \\
\hline $\begin{array}{l}\text { Curriculum, instruction, } \\
\text { assessment }\end{array}$ & $\begin{array}{l}\text { is directly involved in the design and } \\
\text { implementation of curriculum, instruction, and } \\
\text { assessment practices }\end{array}$ \\
\hline Focus & $\begin{array}{l}\text { establishes clear goals and keeps those goals in } \\
\text { the forefront of the school's attention }\end{array}$ \\
\hline $\begin{array}{l}\text { Knowledge of curriculum } \\
\text { instruction assessment }\end{array}$ & $\begin{array}{l}\text { fosters shared beliefs and a sense of community } \\
\text { and cooperation }\end{array}$ \\
\hline Visibility & $\begin{array}{l}\text { has quality contact and interactions with teachers and } \\
\text { students }\end{array}$ \\
\hline Contingent rewards & recognizes and rewards individual accomplishments \\
\hline Communication & $\begin{array}{l}\text { establishes strong lines of communication with teachers } \\
\text { and among students }\end{array}$ \\
\hline Outreach & $\begin{array}{l}\text { advocate and spokesperson for the school to all } \\
\text { stakeholders }\end{array}$ \\
\hline Input & $\begin{array}{l}\text { involves teachers in the design and implementation of } \\
\text { important decisions and policies }\end{array}$ \\
\hline Affirmation & $\begin{array}{l}\text { recognizes and celebrates school accomplishments and } \\
\text { acknowledges failures }\end{array}$ \\
\hline Relationship & $\begin{array}{l}\text { demonstrates an awareness of the personal aspects of } \\
\text { teachers and staff }\end{array}$ \\
\hline Change agent & Willing to and actively challenges the status quo \\
\hline Optimizer & Inspires and leads new and challenging innovations \\
\hline Ideals/beliefs & $\begin{array}{l}\text { communicates and operates from strong ideals and } \\
\text { beliefs about schooling }\end{array}$ \\
\hline Monitors/evaluates & $\begin{array}{l}\text { monitors the effectiveness of school practices and their } \\
\text { impact on student learning }\end{array}$ \\
\hline Flexibility & $\begin{array}{l}\text { adapts his or her leadership behavior to the needs of the } \\
\text { current situation and is comfortable with dissent }\end{array}$ \\
\hline Situational awareness & $\begin{array}{l}\text { aware of the details and undercurrents in the running of } \\
\text { the school and uses this information to address current } \\
\text { and potential problems }\end{array}$ \\
\hline Intellectual stimulation & $\begin{array}{l}\text { ensures that faculty and staff are aware of the most } \\
\text { current theories and practices and makes the discussion } \\
\text { of these a regular aspect of the school's culture }\end{array}$ \\
\hline
\end{tabular}


Hallinger (2001) found that the principal's function as a leader, manager, and agent of change is far reaching. Principals are responsible for working with the entire spectrum of educational stakeholders: students, parents, local business, support staff, teachers, policy makers, and school superintendents. Reviews of literature on principal leadership in the past twenty years have documented a strong relationship between principal effectiveness, instructional leadership and student achievement (Hallinger, 2001; Hallinger \& Heck, 1986; Southworth, 2002).

Senge (1990) refers to the principal as a designer, steward and teacher in the learning environment. According to Senge's research, the principal designs the learning environment to allow the staff and other members to resolve their own issues. As the steward, the principal develops the shared school vision and then supports the teacher in the learning environment. In his Fifth Discipline, Senge describes how institutions of learning can become learning organizations, in a way that promises the revitalization of schools and classrooms. Senge describes schools as the starkest example in modern society of an entire institution modeled after the assembly line. This has dramatically increased educational capability in our time, but it has also created many of the most intractable problems with which students, teachers, and parents struggle to this day. If we want to change schools, it is unlikely to happen until we understand more deeply the core assumptions on which the industrial-age school is based. (p. 17). Senge asserts that schools and educational leaders are often stuck in tradition and industrial aged thinking.

Senge's (1990) research encourages leaders to think systematically in terms of the system as a whole. Senge recommended developing a body of knowledge and related tools in order to understand patterns, identify commonalties, and to assist in implementing effective leadership 
change. Senge affirms that the failure to do this may be the emphasis we place on system thinking rather than system doing. In other words, he says, to educate children well, school superintendents and cafeteria workers alike need to examine how they think about their jobs. They must become aware of deeply embedded assumptions that they may not even know they have, but that can inhibit their performance or blind them to new possibilities (Senge, 1990). In this scenario, all stakeholders are important and responsible for student achievement. In an ever changing world, this research indicates the importance of a principal's continuous renewal of personal mastery and vision. An effective principal must develop a personal vision and the ability to look beyond the current situation. This leadership skill involves perseverance determination and confidence in order to reach established goals. The leader creates or allows a creative tension in order to implement change. Senge's personal mastery is a set of leadership practices that support subordinates, children and adults in keeping their dreams whole, while moving toward resolution (Senge, 1990).

\section{School Effectiveness Research}

Research regarding leadership and its impact on school effectiveness is broad and has a rich history. Beginning with the early 1960s and continuing into the twenty-first century, leadership and school effectiveness have developed close ties. The following section will discuss the school effectiveness research and its impact on school reform. In James Coleman's (Coleman, Campbell, Hobson, McPartand, Mood, Weinfeld, \& York, 1966) On Equality of Education Opportunity, Edmonds (1980) and other researchers, sought to establish that a student's family background and a school's socioeconomic composition were not the top predictors of academic success. This began what is now known as the effective schools research movement. In its simplest form, school effectiveness can be regarded as the extent to which a set 
of goals is achieved and as a reflection of something being done well in an organization or by an individual.

Early studies completed in the era of effective schools research identified principal behaviors related to increased student achievement in reading. The effective schools movement, which began in the mid-1960s, sought to find common characteristics of schools that had exceptional gains in student achievement. Edmonds (1980) concluded that if all students were held to high expectations then student achievement would increase. Richard Murnane (1981) considered the teacher and student connection as the primary influence in student achievement.

In 1982 Ronald Edmonds, then Director of the Center for Urban Studies at Harvard University, formally identified seven correlates of effective schools. The correlates were the leading indicators of schools that achieve high and equitable levels of student learning. Edmond's research identified traits commonly found in effective schools. These included: development and implementation of a clear vision and mission, the principal as a strong instructional leader, and the existence of a positive, safe and orderly school climate. Implementation of a clear vision and mission involves development of a shared leadership among stakeholders. Principals must nurture teacher leadership and broaden skills and attitudes to insure success. A clear vision involves all stakeholders and must coordinate fragmented efforts, build internal capacity to do the work, and develop a knowledge base that will lead to further efforts to restructure. If the principal is to be a strong instructional leader he or she must emphasis academic achievement and time on task, as well demonstrate high expectations for all. A safe and orderly climate reaches beyond metal detectors and dress codes. This correlate involves creation of a climate that is not only safe, but also conducive to effective teaching and learning. Principals must address school issues such as classroom management styles, school 
discipline, self-esteem and aggression, conflict management, and character education (Edmonds, 1982). Moreover, the most effective schools were found using frequent and thorough monitoring of results, and the existence of strong parent and community partnerships with the schools (Edmonds, 1980).

Scheerens and Bosker's (1997) research was well received in the mid to late 1990s. This research involved a wide variety of school reform initiatives and identified eight essential characteristics of successful schools. The characteristics identified include: monitoring of student progress, focus on achievement, parental involvement, creating a safe and orderly climate, focused curriculum, strong leadership, cooperative working environment, and time on task. This research expands Edmonds correlates and begins to define the characteristics of effective school principals.

Marzano (2003) reviewed research on school reform in his book What Works in School: Translating Research into Action. This research identified five characteristics for highly successful schools: guaranteed and viable curriculum, challenging goals and effective feedback, parent and community involvement, a safe and orderly environment, and collegiality and professionalism.

Lezotte's (1989) research noted the following as the most important characteristics of effective schools: creating the school culture, the correlates of effective schools, site-based management, data collection (disaggregation and analysis), the school improvement planning process, organizing schools for students, building community support, and evaluation of student progress. An analysis of this research yields ten central findings which could be used as a basis for success in reform initiatives. First principals must create a culture that embraces the belief that all students need a rigorous and relevant curriculum and that all children can learn. Schools 
have a responsibility to use data to provide the focus for a rigorous and relevant curriculum. Administrators along with teachers must identify what is essential, nice to know, and not necessary. Effective teachers provide students with real-world applications of the skills and knowledge taught in the academic curriculum. Instructional leaders create a framework to organize curriculum that drives instruction. In addition, teachers select curriculum, based upon a student's personal interest, learning style, aptitude, and needs. School leadership sets high expectations that are monitored and holds both students and adults accountable for the student's continuous improvement. Sustained professional development that is focused on the improvement of instruction and parent and community involvement are important in developing successful schools. .It is the responsibility of the principal to establish and maintain safe and orderly schools. At the district level effective leadership development for administrators, teachers, parents, and community must be provided and sustained (Lezotte, \& McKee, 2002). Daggett (2004) completed a meta-analysis of the school effectiveness research, looking for characteristics of successful schools. This research indicated a need for a series of specific characteristics that schools could readily adopt. This examination provided nine central characteristics of high performance focus instruction around students ‘ interests, learning styles, and aptitudes, administrators and teachers share an unrelenting commitment to excellence for all students, especially in the area of literacy, a laser-like focus on data at the classroom level to make daily instructional decisions for individual students, high quality curriculum and instruction that focuses on rigor and relevance, provide students with adults with whom they can develop personal relationships and be allowed the opportunity to use reflective thought, focus and maintain professional development around a limited number of high-impact initiatives, and solid and dedicated leadership. 
Teddlie and Reynolds (2000), a social psychologist from the University of North Carolina at Chapel Hill, provides modern data in the field of school effectiveness. His major writing interests in social science research methodology and school effectiveness include an international research base. Teddlie reviews research practices in terms of design, data collection, and analysis and delivers creative new directions for school leadership by providing five exiting factors in effective schools: strong instructional leadership from the principal, a pervasive and broadly understood instructional focus, a safe and orderly school climate, high expectation for achievement from all students, and the use of student achievement test data for evaluating program, and school success.

Carter's (2000) research includes studies of 23 schools with high student achievement and low socioeconomic status (SES). This study considered 15 public schools, three charter schools, three private schools, one parochial, and one rural school. The schools were diverse in their characteristics; however, all held a high concentration of low SES and high academic achievement. Carter found commonalities among the school Principals were given the freedom to provide school leadership as they deemed necessary and appropriate, and they held established rigorous school goals for student achievement. All staff was held accountable for increasing student progress. Additionally, the principals provided leadership opportunities for master teachers, including team teaching, peer evaluation, and student progress. In each school, principals monitored the results of regular and rigorous assessments, aligned to the curriculum and instruction and prioritized time for learning and instruction (Carter, 2000).

Campbell, Kyriakides, Muijs, and Robinson (2004) differentiated between school effectiveness and teacher effectiveness: school effectiveness refers to the impact that schoollevel factors, such as leadership, school climate, and school policies, have on students 
performance. Teacher effectiveness refers to the impact that classroom factors, such as teaching methods, teacher expectations, classroom organizations, and the use of classroom resources, have on students' achievement. Teacher effectiveness is further defined as the power to realize socially valued objectives agreed for teachers` work, especially, but not exclusively, the work concerned with enabling students to learn" (p.).

\section{Instructional Leadership}

The purpose of this section is to review the research of effective instructional leadership practices. Research supports the importance of the principal as the instructional leader (Edmonds, 1980; Fullan, 2004; Lezotte, 2004). The effective schools movement, initiated during the 1970 's identified the importance of school principals moving away from the role of manager to that of instructional leader (Edmonds, 1980). Paine (2002) defines instructional leadership as principals promoting teaching and learning as the primary focus of schooling. According to the research, instructional leadership requires the principal to have a clear and concise vision, translated into a mission statement (Marzano et al. 2005).

The current national emphasis on accountability has reignited interest in instructional leadership. Strong principals have a clear understanding of teacher capacity and are able to direct teachers regarding effective instructional practices. Effective leaders provide direct assistance to teachers in their day-to-day activities, and make research based decisions (Glickman, Gordon, \& Ross-Gordon, 1995). High expectations for student achievement through curriculum standards and guidelines must be established.

Paine (2002) found that the following are the common practices of effective instructional leaders: aligning standards, curriculum, and instruction; the protection of learning time; establishment of safe school climates; frequent monitoring of student achievement; and the use 
of results to drive instruction and school improvement. Aligning standards, curriculum and instruction causes all the stakeholders to channel what the students need to know and cause consistency in instruction with accountability. Protection of learning time is necessary in student achievement to be able to cover materials needed. Establishment of a safe school climate makes schools better and student learning more productive. We need to monitor student achievement to access the data to improve the instruction.

Andrews and Soder's (1987) research, support Paine's research. They indicate that the major role of the principal is that of instructional leader. In a study conducted in over 200 schools with over 2,500 teachers, Andrews, Soder, and Jacoby (1986) and Andrews and Soder (1987) found a positive correlation between high achieving schools and strong instructional leadership. The schools that were found to have high student achievement also had a principal who had a mission for the school, and a vision for the future of the school. The effective administrators in high achieving schools have a keen ability to get all stakeholders to accept that vision as their own (Marzano et.al. 2005).

Brookover and Lezotte (1979) and Lezotte (1989) agreed that effective principals set high expectations of themselves and staff members, expect continual improvement, and involve the staff in planning, and implementing school improvement. Lezotte and Pepperl (1999) studied effective schools as a continual process of improvement and believed this led to learning for all. They identified core beliefs in this process: all children can learn and come to school motivated to do so; schools control enough variables to assure that all children will learn, and school stakeholders are the most qualified people to implement the needed changes. Other core beliefs include: school personnel who are already doing the best they know how to do, give the 
conditions in which they have been placed, and school by school change is the best hope for reforming schools.

DeBevoise (1984) suggested an effective instructional leader delegates to others to promote growth in student learning. Sergiovanni $(1984,1992)$ referred to instructional leadership as bringing about changes needed to improve schooling, with a shared covenant which articulates core values and provides a standard by which all will be judged. He continued that leaders take the forefront development, support and enforce the covenant. Edmonds (1980) defined the instructional leader as the principal who is focusing on the quality of learning and teaching, the keeper of the vision. In addition, Greenfield (1987) stated that instructional leadership refers to actions undertaken in order to develop a productive and satisfying work environment for teachers and desirable learning conditions and outcomes for children Lezotte and McKee (2002) also identified seven correlates of effective schools in his book Assembly Required. There must be a safe learning environment in which effective schools provide an orderly, purposeful, business-like environment that is free from the threat of harm. Second, a clearly stated and focused mission is important in effective schools to guide and facilitate an educational and financial atmosphere where there is an expectation on the part of each and every staff member that all students can attain mastery of essential school skills. Another correlate includes instructional leadership in which effective schools acknowledge that the principal is the educational leader among leaders, not a leader among followers. A fourth correlate is high expectations for all students in which effective schools hold all staff, including teachers, principals, and the superintendent of schools, accountable for the growth of each student. Next, frequent monitoring of student progress in which effective schools measure academic progress frequently through a variety of assessment procedures is critical. In addition 
maximized learning opportunities in which effective schools allocate a significant amount of time to instruction in the essential skills is vital. Finally, positive communication between the school, home, and the communities in which effective schools can form a meaningful and productive partnership with parents must exist (Lezotte, 1999).

According to Lezotte and Pepperl (1999), there are two kinds of schools in the United States: improving or declining schools. Declining schools maintain the status quo. In order to assist in school improvement, school districts must activate support such as curriculum services and data analysis in order to facilitate and coordinate professional learning communities. The curriculum review team must have in place goals that directly support the school district goals. These studies, based on data analysis and current best practice research, allow the schools and districts to affirm effective practice while providing the direction to lead changes designed to increase student achievement.

Lezotte (1999) asserts that every school can improve. The needed capacity to improve the school resides within the school and all adults in the school are important. Lezotte's research (2004) found that change is a process not an event, and that the existing people are the best agents for change. In order to be effective, principals must learn to initiate, manage, and sustain positive change (Lezotte, 2004).

Hallinger and Murphy (1983) identified three general functions of the instructional leader: define the school's mission, manage curriculum and instruction, and promote a positive school climate. Modern leaders must be able to engage others in developing the mission and vision of the school. All the stakeholders must know what is important. The leader must be able to manage curriculum and instruction to assure that teachers proving the instruction to assure 
student achievement. School climate reflects the overall health of the organization. Research shows that positive school climate goes hand in hand with student achievement.

Howard, Howell, and Brainard (1987) concluded that principals do have the power to change school effectiveness, and that they have a multitude of advocates. The principal must recognize that students, employees, and parents are connected to their school. Drawing and building from these definitions, one is able to conclude that two key features of leadership are a sense of purpose and confidence in followers.

Smith and Andrews (1989) drawing upon literature, research, and studies of principals in practice, present a clear portrait of the instructional leader. According to this research, principals with very different communication, management, and personal styles can prove to be strong instructional leaders. Smith and Andrews believe effective leaders possess the key qualities of resource provider, instructional resource, communicator, and visible presence. The resource provider ensures that teachers have adequate materials to perform their instructional duties. As the instructional resource, the principal should model desired behaviors, participate in professional development activities and provide feedback regarding instructional concerns. As the communicator, the administrator sets clear and concise goals for the school and staff. As a visible presence, the principal frequents the classroom, is highly observable and accessible (Smith et al.).

Waters and Cameron's (2007) research developed eight key leadership responsibilities to insure a purposeful school community: culture, ideas and beliefs, communication, visibility, input, relationships, situational awareness, and affirmation. Culture fosters the shared belief system and the sense of community and cooperation among the stakeholders. Ideas and beliefs communicate and operate from strong ideals and beliefs about schools. Effective 
communication establishes strong lines of understanding with teachers and among students. Visibility refers to quality contact and interactions with teachers and students. Input is defined as the ability of the principal to involve teachers in the design and implementation of important decisions. Relationships demonstrate an awareness of the personal aspects of teachers and staff. Situational awareness is the ability of the leader to be aware of the details and undercurrents in the running of the school and use this information to address current and potential problems. Affirmation recognizes and celebrates school accomplishments and acknowledges failures (Waters \& Cameron, 2007).

Between 1998 and 2003, three major quantitative studies were conducted on the effects of classroom, school, and leadership practices on student achievement. The first reported on nine clusters of research-based instructional strategies with statistically significant effects on student achievement (Marzano, 1998; Marzano, Gaddy \& Dean, 2000).

The second study reported on school practices, also with statistically significant effects on student achievement (Marzano, 2000; 2003). Two studies set the stage for meta-analysis of school-level leadership and it effects on student achievement (Marzano et al. 2005). The third study involved a meta-analysis and found a statistical correlation between leadership and student achievement.

In all of the studies, four characteristics were shared: student achievement as the dependent variable, student achievement measures were all quantitative and standardized; measures of school-level leadership were all quantitative and standardized. The 69 studies in the meta-analyses included more than 14,000 teacher ratings of principal leadership for 2,802 principals. Ratings of principal leadership were correlated with more than 1.4 million student achievement scores. This is possibly one of the largest-ever sample for conducting this type of 
analysis. The findings, conclusions, and technical notes from this meta-analysis have been published in School Leadership that Work, From Research to Results (Marzano et al.2005). In the research, clearly, school-level leadership and student achievement are correlated. The research indicates instructional leadership practices, defined with leadership responsibilities and associated practices correlates these behaviors with student achievement. Marzano (2003) completed an analysis of research conducted over a thirty-five year period. This research found that schools could produce a learning environment which almost entirely overcomes the effects of student backgrounds. Marzano states the guarantee and viable curriculum is the school level factor that most impacts on student achievement

Research has established the importance of instructional leadership; however in order to increase student achievement principal must become reading instructional leaders. The following section describes the research related to reading instructional leadership practices.

\section{Reading Instructional Leadership}

This section will review the major literature related to principals acting in the role of reading instructional leaders. It will also examine the literature related to Reading First, a national initiative, and specifically Reading First as it pertains to the state of West Virginia. Hillard and Guglielmino (2002) stated that reading is the key that opens the gate to opportunity, determining a student's success in school, a vital skill carried forward into adulthood. Principals move away from serving as building managers when they become reading instructional leaders. They must provide a vision, create ownership, set priorities, remove barriers, foster peer support, and model the behavior desired (Hillard Guglielmino, 2002).

Principal reading instructional leadership and knowledge of reading will assist the school leader in interacting more effectively with the entire school community (Edmonds, 1982). 
According to this research, principals who have depth of knowledge in reading are better prepared to have discussions with classroom teachers focused on instruction and student achievement. In another research study, it was found that in order to be effective leaders, principals must be involved in staffing, staff development, monitoring student achievement, vision sharing, and working with community and parents (Braughton \& Riley, 1991).

Learning Points Associates (2004) is a national nonprofit study group of leading scholars that provides strategies and was organized and supported through the North Central Regional Educational Laboratory a wholly owned subsidiary at Columbia University Teachers College based in Naperville, Illinois. Learning Points (2004) acknowledged that effective instructional leadership requires involvement in reading instruction. This document offers the following guidelines to ensure success: make certain that the instructional reading program is comprehensive and research-based, schedule and protect time for reading instruction each day, guarantee necessary materials are available for all K-3 classrooms, set goals for reading instruction monitor the instructional reading program, be confident that teachers fully understand and support the new reading program, and observe the classroom frequently and be prepared to give extra attention to certain teachers.

Ferrandino and Tirozzi (2001), respective presidents of the National Associations for Elementary and Secondary Principals, believe - tnder-developed literacy skills are the number one reason students are retained, assigned to special education, given long-term remedial services" (p. 488). Recognizing the importance of reading instruction, the West Virginia Department of Education asserts that in order to ensure academic achievement for all students principals must: make decisions to embrace intervention, implement a literacy intervention plan, 
begin important conversations around instruction and data, and support teachers in charge of delivering curriculum (West Virginia Department Education, 2008).

Fullan (2001) said that the principal is the gatekeeper of change, often determining the fate of innovations. Response to Intervention (RTI) is a major initiative in all West Virginia schools. The core beliefs of RTI are: the belief that WV teachers can effectively teach all children, early intervention is essential, use of a multi-tier model of service delivery, use of a problem solving model to make decisions within a multi-tier model, use of scientific, researchbased validated instruction and intervention, use of data to make decisions and monitor student progress to inform instruction, use of assessment for screening, diagnostics and progress monitoring. Leading the RTI process is the process of tiered instruction. Tiered Instruction is about meeting each student where he or she instructionally or behaviorally, using all staff and all minutes in the school day (West Virginia Department Education, 2008).

Cumins (2006) wrote that the current educational agenda of No Child Left Behind requires administrators and teachers to work together to improve reading achievement for all students. This goal forces administrators to become agents of change and instructional leaders. A study conducted by Blasé and Blasé (2000) asked teachers to describe the behavior of administrators who made an impact on student learning. Two major behaviors were identified: 1) talking to teachers about instructional issues, and 2) promoting their professional growth. According to Lezotte (2004), instructional leadership correlates to effective schools. The leadership skills and abilities of school principals are critical in assuring the success of students in schools. As Bolman and Deal (2006) noted the spirit of this role requires principals to employ an extensive range of leadership approaches to ensure the success of their reading programs. 
The role of school administrators in professional development is the key to teacher growth, and the principal is a key element to the success of professional development. Many scholars have contributed their thoughts on what the definition of school leadership is, and they also offer suggestions for how leaders might approach decision making. Lezotte and McKee (2000) found that effective schools focus on results and simultaneously consider quality and equity, are data-driven, and are research-based. Collins' (2001) research indicates that effective teamwork is fundamental to a school's ability to decrease the achievement gap between lowachieving and high-achieving students. Collins deserves effective leaders as level 5, who are more interested in building a great school rather than drawing attention to themselves. This involves intense commitment, relying on high standards, surrounding themselves with the right people, creating a culture of discipline, and considering the difficult questions regarding the future of the school (Collins, 2001).

Taylor, Jones, and Valentine (1985) divided effective schools into three sections: effective principals, effective classrooms, and effective teachers. While individual leaders act, they do so in a situation that is defined in part by the actions of others their actions are interdependent, it is in these interactions leadership practice takes shape.

Fullan (2001) refers to leadership as the driving force behind change taking place in schools. The leadership role of the principal is central in helping build strong literacy programs. Principals establish school climate and are directly involved in literacy decisions. Schools that have successful literacy programs also have strong leadership with focus on literacy, supporting teachers, assessing resources and building capacity for future growth.

The International Reading Association identified five domains in which principal‘s impact reading instruction: working with teachers, working with students, creating a building 
atmosphere, providing policy leadership, and building community support (Motley \& McNinch, 1984). In working with teachers the principal must make sure professional development is provided. The building principal must be familiar with assessment of students and be able to analyze the date help the teachers drive the instruction. The principals must build an atmosphere that support resources needed for students to achieve. The principal must provide the leadership and gain the community support for the reading in his or her school.

An important component of Reading First is to build strong instructional leadership in schools. The instructional leaders must have a clear vision of effective reading instruction and scientifically based reading research. In addition, the leadership must also be willing to constantly monitor the progress of programs and instruction to be certain that high-quality program implementation is occurring and that all students are making satisfactory progress. In addition, leaders need to understand how to make informed data-based instructional decisions. Building a foundation for strong reading leadership teams at the state, county, and school levels is a critical step toward achieving the overall goal of improved student outcomes in reading for all students, including students with special and diverse learning needs.

\section{Reading First}

The purpose of Reading First was to make certain that all children in America learn to read well by the end of the third grade. This goal was to be met by utilizing quality interventions matched to student needs, in addition formative evaluation is utilized to obtain data over time to make critical educational decisions (NASDSE, 2005). Reading First provides assistance to states and districts to establish scientifically-based reading programs. Supporting funds increase professional development to ensure that all teachers have the skills they need to teach these programs effectively. Reading First also supports the use of screening and diagnostic tools and 
classroom-based instructional reading assessments to measure how well students are reading and to monitor their progress.

Mandates outlined in Reading First, part of No Child Left Behind, have changed the role of administrators. Principals must now juggle the demands of management, become leaders of change, and act as literacy instructional leaders. According to Lashway (2002), principals also need to align staff development with student learning needs. Administrators are challenged to make every child a reader by the third grade. Traditionally, principals have acted as school managers. Today, however, they need additional expertise to make a serious impact on literacy in their schools. In her report for the report of the National Reading Panel, Northup (2000) summed up the argument for national reading reform as a child's success in school and in life is dependent upon the child's ability to read. Most discouraging is that nearly 60 percent of America's fourth graders cannot read at a proficient level. Northup believes that in order to reach these youngsters now, we cannot come back fifteen years later and make it right.

The Reading First section of No Child Left Behind contributed to the call for scientifically-based reading research. Scientifically-based reading research (SBRR) must be the focus of all quality Reading instruction (United States Department of Education, 2002). SBRR applies rigorous, systematic and objective procedures to obtain valid knowledge relevant to reading development, reading instruction and reading difficulties (West Virginia Department Education, 2002). The SBRR methods employ systematic, empirical methods and involve rigorous data analyses that are adequate to test the stated hypotheses and justify the general considerations drawn. Valerie Reyna, Deputy of the Office of Educational Research and Improvement states that first we should think about what the alternative to scientific research is? If you didn't base practice on scientific research, what do you base it on?" (United States Department 
of Education, 2002, p .4). Mandates of No Child Left Behind led to dramatic change of instructional programming in schools across the nation.

The West Virginia Reading First plan incorporates scientifically-based reading research and includes the selection and implementation of instructional materials and programs, instructional strategies, assessments, and professional development. Title I provides the funding for Reading First. The reading reform goal is to have all students reading on level by the time they reach the third grade.

To successfully build the capacity to improve and to sustain statewide reading achievement, Reading First must build leaders (Cummins, 2006). Liberman and Miller (1984) explained that building the level of leadership is critical to school improvement. Project directors and principals at each Reading First school are the instructional leaders, and they need as much professional development as teachers so they can be directly involved in all aspects of the Reading First project. The school-wide reading model for Reading First involves leadership and a strong reading culture. Effective leaders establish both and create schools with the greatest potential for sustaining the model over time as initial funding disappears. Strong leadership and a reading culture will take scientifically-based reading instruction, from a federally supported initiative, to being the way reading is taught in a school or district.

The Reading First initiative involves several key components. The four pillars" of the program include: valid and reliable assessments, instructional programs and aligned materials, aligned professional development, and dynamic instructional leadership (United States Department of Education, 2006). First, assessments must include screenings, diagnostics progress monitoring and outcome assessments to assist teachers in identification of student skills and deficiencies. Second, instructional programs and aligned materials emphasize the five 
essential components of effective reading instruction. The programs and materials are focused and sequenced to assure students have enough time to learn, practice and apply skills they have been taught. Third, professional development is strong and aligned with instructional programs. These programs allow time for teachers to learn and apply their professional knowledge. Finally, instructional leadership is dynamic and recognizes the importance of the principal. According to the pillars of Reading First, administrators are important resource providers, coaches and are responsible for establishing clear goals and expectations for student learning (United States Department of Education, 2006).

Spillane (2006) concluded that school-level conditions and school leadership, in particular, are key issues in the effort to change instruction. The Reading First program is the foundation on which teachers can build scientifically-based reading research instruction into their classes. West Virginia received approximately $\$ 43.8$ million over a six-year period from 2002 - 2008 to maintain its Reading First grant. After the first three years, schools that showed success in raising student achievement received additional funding for an additional three years to continue implementing their Reading First program.

In West Virginia RTI is rooted in the foundations of the Reading First Program. Schools were selected based on specified criteria to examine effective practices and initiatives. The schools that received Reading First funds confirmed a high rate of both poverty and student needs to qualify for the program. In West Virginia twenty-five counties were involved with Reading First, and thirty-six principals and staff members received funding. The schools were the 2004 grantees of Reading First funding. The first round of the grant funded twenty-two counties, and the second round funded the remaining three counties. The schools range in size and organization, and were all elementary schools that met the guidelines of the Reading First 
grant. The West Virginia Department of Education's (2002) Reading First proposal encompassed the basic idea of improving reading instruction in low-performing K-3 classrooms. The schools had basic premises to follow:

1. Core content/instructional development and classroom implementation.

2. Professional development content.

3. Classroom management and organization to ensure quality instruction.

4. Teacher quality enhancement to ensure qualified personnel.

In addition, premise number one further encompasses knowledge of both scientifically-based reading research and the five essential components of reading (outlined below). Premise number -two also incorporates scientifically-based reading research, but outlines the selection of appropriate instructional programs, the appropriate use of evaluation results, and adequate student access to printed materials. Vaughn and Thompson (2004) state that without scientifically-based approaches that are validated by research, students are at risk and will be left behind. Principals of Reading First Schools had to sign a principal participation assurance.

That assurance included in the subgrants application that the school principal had to be committed to: attend all Reading First professional development activities; meet monthly with the school's Reading Mentor Teacher for program planning and evaluation; present the school's Reading First plan to the school and community; provide the Reading First district project director with reports; school data and information as required; serve on district and state Reading First committees as requested; and attend district and state reading meetings. A school was not considered for funding if the principal was not committed to the success of the project.

All WV principals received their own training in scientifically based reading research in June 2002. This three-day training involved the five basic components of reading, the nature of 
scientifically based reading research, and successful observation of a reading classroom. Thus, most principals had a beginning knowledge about reading.

The report of the National Reading Panel (United States Department of Health and Human Services, 2000) identified five essential components that must be incorporated into highquality reading programs. These components are: phonemic awareness (learning sounds in words), phonic (understanding sound/letter relationship), fluency (oral and written reading proficiency), vocabulary (building a rich sort of words and meaning), and comprehension (understanding the meaning or oral and written language). These five components formed the foundation of instruction for Reading First schools.

Phonemic awareness entails recognizing the individual sounds (phonemes) in spoken words. Phonemes are the smallest unit composing spoken language. Phonics instruction is an essential ingredient in early reading instruction. The purpose is to teach children how to read with accuracy, comprehension, fluency, and pleasure. Beck (2006) wrote that beginning readers learn better when teachers emphasize these relationships. The report of the National Reading Panel (United States Department of Health and Human Services, 2000) noted that the many different definitions of fluency involve speed in word recognition, freedom from word recognition errors, and automatic information processing from text. Vocabulary is a critically important component of reading comprehension. If children lack knowledge about words, their comprehension will be seriously impaired. Johns and Berglund (2002) believe that the differences in the number of words learned relates to a child's experience with printed material.

The fifth critical component of the five-component model of reading is comprehension. After all, reading is about making sense of text; it is far more important than decoding all the words correctly. Zimmermann and Hutchins (2003) found that comprehension is critically 
dependent on prior (or background) knowledge. Gentry (1999) wrote that teachers must work quickly to know all the students in their classroom so that they become aware of students reading abilities.

This type of preventive approach to reading difficulties is based on several significant premises about early reading. All but a few children have the ability to read and preventing reading difficulties in kindergarten through third grade is far more cost-effective and efficient than remediation in later grades. Hall (2006) stated that one of the most important changes in education this decade is the realization that early identification and intervention can prevent reading problems. To put research into practice, a school will need to implement three ideas from Hall:

1. A systematic process for periodically screening all students in kindergarten through third grade to determine which students are not meeting critical milestones in early literacy.

2. Procedures to provide data-informed intervention instruction in small groups when a student's scores on the screening indicate $\mathrm{s} /$ he is at risk for later reading difficulty or already experiencing difficulty.

3. Continued monitoring to ensure that the instruction is helping and that the struggling student stays on track once the benchmark is reached.

Reading First schools focus on effective research-based reading instructional practices, provide knowledge in each of the five cornerstone areas, and provide opportunities for planning and practice. The teaching staff's development is the first important benchmark in the design of the program. Teachers must have opportunities to learn the most effective instructional strategies, practices, and programs based on scientific research (Beers, 2002). Guskey (2000) 
stated teacher professional development provides much needed capacity for continuous improvement.

\section{Electronic Dissertation Analysis}

An electronic search of educational databases was conducted utilizing Dissertation Abstracts Online Database using the keywords, principal", "instruction leader", and reading". From those keywords a total of 36 studies were found. Of these, 19 used qualitative methods for design, 14 used a quantitative one and three used a mixed methods approach.

In the 14 quantitative studies, surveys were used most frequently as the instrument in seeking out the principal's role as reading instructional leader. Of these 14 studies, eight were conducted at the elementary level, three at the high school level and three incorporated mixed levels. Data was collected through correlational studies using test scores to measure student achievement. The collected data were analyzed using a variety of statistical techniques such as ttest, one-way analysis of variance, Chi-square tests, linear model analysis, and Pearson correlation.

Of the 19 qualitative studies, the most frequently used methods of collecting data were interviews of principals. Thirteen studies were found that used qualitative research design of subjects at the elementary level, two at high school and four middle schools. Of the qualitative studies, the most frequently used methods of collecting data were interviews of principals.

In the last 20 years much attention has been paid to educational leadership and its impact upon student achievement. Leithwood \& Jantzi (2000) stated that the effective principal comes to the fore as an instructional leader who affects student achievement.

The studies selected for inclusion in this literature review had similar goals and were most relevant to the proposed research questions. In particular they investigated the principal's 
role in increasing achievement in literacy. The dissertations selected for inclusion in this literature review also employed quantitative methodology similar to the methods proposed for this research. The most common methods for data collection were surveys. Several dissertations forward on the role of the principals as instructional leaders.

The two studies that are most relevant to the proposed research of reading instructional principals in public schools are reviewed. The first study is Christine S. Lay`s (2007) review of Reading to Intervention programs in Pennsylvania. The second study is that of middle level reading instructional leaders in West Virginia by Mary Porter (2001). The first study by Christine Lay identified the leadership responsibilities needed to implement a Progress Monitoring Program that incorporates a Response to Intervention (RTI) Model for a systemwide change in literacy. This study examined whether the key leadership responsibilities varied based on the phase of the implementation of the RTI Model. The McRel's Balanced Leadership Profile 360TM survey was administered to RTI Model school leaders as a self-reporting instrument. In this survey principals were asked to identify the degree to which they believed certain leadership practices and reading techniques had impacted the reading achievement scores at their respective schools. Based on the five domains of effective leadership (Motley \& McNinch, 1984), the survey also measured the principals‘ beliefs about reading and its relationship to their reading instructional leadership practices. The 200 teachers involved in the RTI implementations completed the survey to evaluate their ten principals.

Interviews were conducted with a sample population of teachers to confirm the survey finding. Observations of principals were performed to verify the presence of identified leadership responsibilities. The findings of this study indicated principals involved in RTI initiatives, at all levels of implementation, perceived this as having second order change magnitude. 
The teachers' responses on the McRel's Balanced Leadership Profile 360 TM survey were varied and their interview responses identified communication, focus, input, and knowledge of curriculum, resources, assessment, and order as the primary responsibilities needed by a school leader to implement the RTI initiative. Three Dynamic Indicators of Basic Early Skills (DIBELS) measures were administered to all students in grades one through four, included in the Project MP3. These benchmark results were used to identify students for the different subgroups of the Response to Intervention Framework. All teachers involved in the implementation of a Response to Intervention model completed a 92-item questionnaire with multiple questions for each responsibility.

The second study was by Mary Porter (2001) who reviewed reading instructional leadership of middle level principals in West Virginia public schools. The purpose of this study was to focus on the background, beliefs, and reading instructional leadership practices of principals in selected West Virginia public schools that contained middle level grades. Porter's research is a quantitative, correlational study. The research indicates the need to identify specific effective behaviors of reading instructional leadership at the secondary level and the impact it may have on achievement test scores.

Porter (2001) focused on 617 middle level principals in West Virginia who represented a variety of grade level configurations in schools with grade levels five through eight. A random sample was taken so that $20 \%$ of each middle level segment of the principal population would be represented. The Statistical Analysis Software (SAS) system was used to analyze the data. Test scores on the Stanford Achievement Test (SAT 9) reading battery were the dependent variable. Independent variables included demographic conditions, and the grade level configurations of the school. Principals were asked to identify through a survey the degree to which they believed 
certain leadership practices and reading techniques impacted the reading achievement scores at their schools.

Porter's survey was based on the five domains of effective leadership identified by Motley and McNinch (1984) and recommended by the International Reading Association. The domains included: working with teachers, working with students, creating a building atmosphere, providing policy leadership, and building community support. Careful review of these sources was used to develop a 93 item survey of five parts.

Porter's research had five conclusions. First, principals` experience both as a teacher and principal provided the information and background skill that are needed to be a reading instructional leader. Second, the following 6 behaviors of reading instructional leadership were report at resource providers, disseminate and share information about test scores and data, set goals, provide staff development, check lesson plans and provide feedback to teachers. Third, the principal believes that they can impact reading test scores and must try to devote more time to this area. Fourth, a finding was that as many as two-thirds of the principals in the report had either taken a reading course or taught reading. Finally, Porter (2001) concluded that educating the principals in reading instruction is a likely predicator of student reading achievement. From this search, it is believed that this proposed study may be the first to explore the relationships between Reading First and non-Reading First, principals‘ professional development, reading instructional leadership practices and the students' Reading/Language Art test scores as measured by the WESTEST during 2005, 2006, and 2007 from each group.

\section{Summary}

The review of the research related to leadership, school effectiveness, instructional leadership, reading instructional leadership practices, and Reading First practices demonstrates a 
strong connection between instructional leadership practices, school effectiveness and student achievement. Improving reading achievement for all students requires both effective practices and the willingness to forge ahead in the endeavor. This study was used to compare the reading instructional leadership practices and professional development of 40 Reading First principals with 40 non-Reading First principals. There were 40 Reading First West Virginia K-5 public elementary principals, leaving 303 from which to select 40 non-Reading First West Virginia K-5 public elementary principals by a random. The study also compared the percentage of students who have scored mastery or above as measured by the third grade Reading/Language Arts West Virginia Educational Standards Test (WESTEST) in the years 2005, 2006, and 2007. A presentation of the research methodology used to examine the reading instruction leadership practices and principals‘ professional development will be present in Chapter Three. 


\section{CHAPTER III METHOD}

This chapter describes the research method used to examine the reading instructional leadership practices and professional development of principals in 343 West Virginia K-5 public elementary schools. The purpose of this study was to compare the reading instructional leadership practices and professional development of 40 Reading First principals with 40 nonReading First principals. There are 40 Reading First West Virginia K-5 public elementary principals, leaving 303 from which to select 40 non-Reading First West Virginia K-5 public elementary principals by a random sample. The study also compared the percentage of students who scored mastery or above as measured by the third grade Reading/Language Arts West Virginia Educational Standards Test (WESTEST) in the years 2005, 2006, and 2007. These years were specifically chosen based on the initiation of the WESTEST 2 during the 2008 school year. In addition, gaps in student achievement were considered.

The methods used in this study are discussed in this chapter. It is structured in 10 sections: Research Design, Research Participants, Survey Instrument, Survey Development, Reliability and Validity, Panel of Experts, Pilot Study, Data Dissemination and Collection, Data Analysis, and Summary.

\section{Research Design}

The overall research compared differences between Reading First and Non-Reading First, principals': (1) reading instructional leadership, (2) professional development, and practices, and (3) the students' Reading/Language Arts test scores as measured by the WESTEST during 2005, 2006, and 2007 from both groups (Reading First and non-Reading First). The WESTEST was the educational achievement test used during that time period. The performance levels from highest to lowest were: distinguished, above mastery, mastery, partial mastery, and novice. The 
WESTEST was administered to students in grades 3-8 in the subject areas of Math, Science, Social Studies, and Reading/Language Arts.

This study determined whether there were statistically significant differences between the variables in the Reading First Schools compared to the non-Reading First Schools. These three variables included: reading instructional leadership practices of the principals, professional development, and WESTEST scores. The study also examined the means of the principals demographic data: gender, years spent teaching reading, number of reading courses taken, years as principal in what grade level, and hours spent on instructional issues.

The three research questions were:

(1) Do the reading-instructional-leadership practices of principals differ in Reading First Schools versus non-Reading First Schools?

(2) Does the reading-instructional-leadership professional development of principals differ in Reading First Schools versus non-Reading First Schools?

3) Is there a difference in Reading/Language Arts WESTEST scores for the years 2005, 2006, and 2007 for third grade students in Reading First versus non-Reading First Schools?

The population of elementary principals was 343 in West Virginia K-5 public schools. To come up with a sample of Reading First and non-Reading First Schools, a sample was 40 Reading First and 40 non-Reading First Schools were selected, for a total of 80 principals.

The principals in the sample were sent a survey with Likert-type items that was a selfreporting, web-based survey, developed utilizing Survey Monkey. According to Gay, ( 2006) the survey method is useful for investigating a variety of educational problems and issues and was characteristically concerned with assessing attitudes, preferences, demographics, and practices. 


\section{Research Participants}

The population of this study was West Virginia K-5 public elementary school principals. There were a total of 343 elementary schools in West Virginia. Of the 343 K-5 public elementary schools in West Virginia, 40 were Reading First. The 21 counties that had Reading First Schools are shown in Appendix I, West Virginia Original Reading First Counties. To assure proper response rates, this study included data from all 303 non-Reading First Schools, thus assuring responses from at least 40 schools. Of those non-Reading First Schools that completed surveys, 40 were selected. A table of random numbers was used to select the 40 non-Reading First Schools. Random sampling (Rand, 2002) was used to obtain a sample of non-Reading First Schools from the population in this study. The total number of schools was 343, and the total number of principals in the overall sample was 80 (40 from Reading First Schools and 40 from non-Reading First Schools). However, if a lower number than 40 Reading First principal responses were obtained, that same number of principal responses would be matched from nonReading First Schools.

\section{Survey Instrumentation}

The self-reporting survey instrument (Survey of Public Elementary Principals in West Virginia Reading Instructional Leadership), located in Appendix A, included a one page cover letter printed on WVU letterhead, and two pages of items divided into five sections numbers 1-5. The survey cover letter provided contact information for questions, directions for amount of time and return information, notice of voluntary participation, anonymity, confidentiality, and purpose of survey. The letter included a stipulation to share results with participants upon request (see Appendix B). 
The survey response requests were divided into five sections. Section 1-3 were a selfreporting survey instrument with items that were adapted from Porter (2001) who derived them from the reading literature concerning leadership practices of principals and reading instructional practices. The survey for Porter's study was based on the five domains of effective leadership that were identified by Motley and McNinch (1984). Each domain became the basis for generating survey items. These domains included: working with teachers, working with students, creating a building atmosphere, providing policy leadership, and building community support. These domains also paralleled with the International Reading Association Standards for Reading Professionals (see Appendix C and D).

Sections 1-3 of the survey contained 27 questions. Section 1, questions 1 through 6 assessed Principal as Resource Provider.” Section 2, questions 7 through 17 assessed Principal Interacts with Teachers." Section 3, questions 18 through 27 assessed Principals Assures Climate Conducive to Literacy Development." The respondents were given the following instructions: For each statement select the number that most accurately describes how often you perform each of the following to help student achievement for children in your school." The choices were:

1. NEVER

2. SELDOM

3. SOMETIMES

\section{OFTEN}

Section 4 contained 12 questions, instructing the principals to - Check either YES or NO to indicate whether each of the following has helped you acquire the skills and information you need as the reading instructional leader in you school." The professional development resources 
utilized by principals in attempting to improve instruction, and ultimately raise reading test scores were studied.

Section 5 contained 10 demographic items for the principal to answer: years in current position, years in Reading First grant gender, years spent teaching reading, number of reading courses taken, years as principal and what level, and number of hours spent on instructional issues.

\section{Survey Development}

A comprehensive review of the literature pertaining to principals as reading instructional leaders was conducted. A four-stage procedure guaranteed both validity and reliability of the survey (Suskie, 1996). These four stages were described subsequently (Gay, 2006).

Dissemination and collection of the survey took place over a three-week period based on a predetermined timeline developed to both promote participant involvement and to decrease procrastination. The survey examined the instructional leadership practices and professional development of the principals, and 3 years of achievement test data.

The research used for this survey instrument was adapted from the work of Dr. Mary Porter (2001). The purpose of Porter's research indicated the need to identify effective behaviors of reading instructional leadership at the secondary level which would impact student achievement test scores. Porter's research focused on the self reporting background and reading instructional leadership practices of principals in selected West Virginia public schools that contained middle- level grades. Porter's work was based on established correlations between the principals‘ instructional leadership behaviors and school outcomes, including student achievement (Bossert, Dwyer Rowan, \& Lee 1982; Hallinger \& Murphy, 1983; Pitner, 1988). Additional research (Boyan, 1988; Heck, Larsen, \& Marcoulides, 1990) has established a 
correlation between school effectiveness and student achievement which suggests that leadership directly impacts academic achievement. Brookover (1987) identified principal leadership as a correlate of effective schools, and cautioned that leadership alone is not sufficient to produce high achievement.

Dr. Mary Porter's research (2001) regarding reading leadership behaviors and practices was used to adapt the survey for this study. Porter's study, Reading Instructional Leadership: A Survey of Middle Level Principals in West Virginia Public Schools surveyed middle level principals in West Virginia. Porter concluded that principals believed their impact on reading test scores was evidenced by their experience, both as a teacher and as a principal, and skills they needed to be effective reading instructional leaders. Porter (2001) found that If we are to change and improve reading, then we must begin with the preparation of instructional leaders who are to become the agents of that change" (p. 100). She further concluded that principals identified themselves as resource providers in activities such as: the dissemination and sharing of information regarding test score data, goal-setting, staff development, and the review of lesson plans with immediate feedback to the teachers. Perhaps most surprising was that two-thirds of the principals in Porter's report had either not taken a reading course or had never taught reading.

\section{Reliability and Validity}

Key to the development of the self-reporting survey was the instrument's validity and reliability. Reliability refers to the consistency of a measure. Test-retest reliability refers to consistency across time. In this research, we considered if a principal responded similarly to the same items when responding to them again after a two-week interval. Is the instrument userfriendly with an easily understood format and clear directions (Suskie, 1996)? Validity is the degree to which an instrument measures what it is intended to measure. Do all the survey items 
relate to the research topic and have mutually exclusive questions or statements (Hinkle, Wierma, \& Jurs, 2003)?

In order to properly address the issue of validity and reliability, a four-stage evaluation (adapted from Davies, 2009) process was utilized (Gay, 2006):

- Stage One (validity): A panel of experts knowledgeable of the Reading First program reviewed the survey instrument to ensure appropriateness of the survey questions and statements.

- Stage Two (reliability): pools of K-5 public elementary school principals in West Virginia were involved in a pilot study.

- Stage Three (reliability): A pilot group of K-5 public elementary school principals completed the survey followed by a face-to-face interview. West Virginia K-5 public elementary school principals were randomly selected for participation. Following their selection, an observation and group discussion was conducted by the researcher to edit the survey.

- Stage Four (reliability): Based on feedback provided through previous evaluation stages, final editing was completed by the researcher.

\section{Panel of Experts}

Using a panel of experts was a group process that involved an interaction between the researcher and a group of experts on a specified topic (Yousuf, 2007). The three-member panel of experts included three state Reading First experts. This panel of experts was selected and utilized in the development of the survey instrument used in The Perceptions of Practicing West Virginia K-3 Reading Teachers of Working with Reading First Coaches in Title I Distinguished Schools (Davies, 2009). The first state expert, Mrs. Beverly Kingery, was a former state Reading 
First Director and lead author of the West Virginia Reading First Grant. Mrs. Kingery currently holds the position of Superintendent of Nicholas County Schools, a Reading First county. The second state expert was Ms. Phyllis Veith, who works for the West Virginia Department of Education as a Reading First Director. She is responsible for all state reading initiatives, Reading First grants, and Reading for All. The third state expert, was Catherine A. Thompson, was a Reading First Coordinator for WVDE. Mrs. Thompson currently holds the position of Principal at Eastern Greenbrier Middle School. In addition, two State reading cadre members, Mrs. Nancy Cook and Mrs. Rebecca Wood, were alternatives if one member is unable to meet the obligation.

The panel of experts was contacted via electronic email to request participation. Upon acceptance, a second email was sent to each panel member containing reference to three attachments: 1) reviewer directions for the panel of experts (Directions and Review Instrument for Panel of Experts, see Appendix E), 2) a copy of the draft survey (Survey of Public Elementary School Principals in West Virginia, see Appendix A), and three questions posed to the panel of experts (Appendix H).

Three questions (adapted from Davies, 2009) were posed for the panel's consideration regarding the survey:

1. Đo the questions and statements adequately address the study research questions as guided by a comprehensive review of the literature?"

2. Đo the questions and statements contain the necessary information to enable an adequate response by the respondent?"

3. Is each question or statement biased or worded to encourage a particular response?" (Davies, 2009, p. 52) 
Panel members changed wording of items if necessary. As indicated on the Directions and was completed Review Instrument for the Panel of Experts (see Appendix E), these questions were central to each item included on the survey. The panel provided written feedback within one week and the items were revised in consultation with the committee chair.

\section{Pilot Study}

In order to establish the reliability of this particular study, a pilot study was conducted from a pool of K-5 public elementary school principals from schools located in the eastern panhandle of West Virginia. The counties included were: Hampshire, Mineral, and Hardy. A pilot study was a small scale-version, or trial run done in preparation for a major study (Gay, 2006). Three K-5 public elementary school principals completed the on-line survey (Appendix G) in order to test the research instrument to see if it were user friendly. A discussion regarding the technique, directions, and feasibility of the research after the pilot was concluded. One of the three principals was randomly selected from the pilot group to be observed by the researcher, participating in a discussion regarding the actual improvements made to the study design and the research process. No feedback was received.

\section{Data Dissemination and Collection}

The survey was presented to West Virginia K-5 public elementary school principals via a one/month, web-based computer survey using Survey Monkey during one month. Emails to county superintendents notified them about the research, and preceded principal surveys. Superintendents received a courtesy email regarding the involvement of principals in 55 participating counties. (See Superintendent Notification Letter in Appendix F).

Gay (2006) recommends providing two to three weeks for data completion. This allowed adequate time for participants to respond to the survey. The following was the timeline (outlined 
in Appendix J) used in data collection. In a one-week period following the superintendents notice, the dissemination and collection process was initiated. In an effort to maximize the response rate, the samples of 343 principals were invited up to a maximum of three times to participate in the study using the automatic email feature of Survey Monkey. First, the principals received an invitational email directing potential participants to the web-based survey via the URL. A reminder email was sent requesting participation in the electronic survey. In the third week, if the principal had not responded, a final reminder email was sent.

Week One: Email was sent to participants inviting participation in a doctoral research study, electronic survey URL included in email.

Week Two: a reminder email to remaining non-respondents.

Week Three: a final email reminder.

Davies (2009) stated the growth of internet usage and web- based communication increased research methods that provide greater flexibility in data collection.

Electronic surveys have removed many restrictions from researchers and increased flexibility regarding when and where subjects may participate (Bonham, Titus, Beichner \& Martin, 2000). Many researchers have found advantages to the utilization of electronic surveys and web-based surveys which categorize and store data electronically to be used conveniently for later analysis (Lazar \& Preece, 1999). Cost and time are other advantages in using electronic surveys.

The three most common reasons for selecting electronic surveys over a pencil-paper approach are: decreased costs, faster response rates, and increased response rates (Lazar \& Preece, 1999; Oppermann, 1995; Saris, 1991). Research is beginning to confirm that electronic surveys provide strong advantages of speedy distribution and response cycles (Swoboda, Muehlberger, Weitunat, \& Schneeweiss, 1997; Yun \& Trumbo, 2000). As use of web-based 
surveys increases, issues regarding utilization must be considered: security, access, privacy, and ethical issues should also be considered (Lazar \& Preece, 1999, Schmidt, 1997). Each of these areas was addressed during the development of the survey using Survey Monkey. For example, each participant received an access code which allowed only the respondent and the researcher access to the responses.

The anticipated participant return rate was set according to survey research. Most researchers desire $70 \%$ to $80 \%$ response rate and consider $50 \%$ minimally adequate according to Suskie (1996). This population consists of 343 K-5 public elementary school principals; a return of 80 questionnaires was desired. In the accompanying survey, principals were asked to return the survey within 14 days.

\section{Data Analysis}

Appropriate comparisons were computed via $t$-test analyses in which the independent variable is School (Reading First versus non-Reading First). For such $t$-test analyses, potential dependent variables are Section 1 (e.g., Principal as Resource Provider with Range from 6 to 24, Principal Interacts with Teachers with Range from 11 to 44, and Principal Assurance of School Climate Conducive to Literacy Development with Range from 10 to 40.) The variables to be involved in the analyses are listed in Table 2. 
Table 2

Variables Involved in the Analyses

\begin{tabular}{|l|l|}
\hline \multicolumn{1}{|c|}{ Variables } & \multicolumn{1}{|c|}{ Range } \\
\hline School Type & (1) Reading First (2) non-Reading First \\
\hline Section 1-3 of Survey & 6 to 24 \\
Principal as Resource Provider & 11 to 44 \\
Principal Interacts with Teachers & 10 to 40 \\
Principal Assures Climate & \\
\hline Section 4 of Survey & All - Yes/No \\
Undergraduate course & \\
Graduate courses & \\
Journals/articles & \\
Reading First state department training & \\
RESA training & \\
Principal's Academy & \\
Teaching experience & \\
Experience as a principal & \\
Interaction with teachers/reading specialist & \\
\hline Section 5 of Survey & Various Range \\
Years in position & \\
Gender & \\
Number of reading courses taken & \\
Years of experience as principal at what level & \\
Percent of day spent on instructional issues & \\
\hline
\end{tabular}

Table 2 shows the sections and ranges of scores from the survey. Analyses for this study involved both descriptive and inferential statistics. To establish whether or not significant statistical differences exist, three research questions were considered.

\section{Research Question 1.}

Do the reading-instructional-leadership practices of principals differ in Reading First Schools versus non-Reading First Schools?

This research question was tested through responses to 27 items in three sections. There were six items in the first section, Principal as Resource Provider. There were eleven items in the second section, Principal Interaction with Teachers. There were ten items in the third 
section, Principal Assurance of School Climate Conductive to Literacy Development. A $t$-test was computed for each of the items to determine if the Reading First principals $(n=28)$ rated the items differently from the non-Reading First principals $(n=28)$.

To assess potential differences in the ratings of the two groups of principals, a $t$ test was computed for each of the items. Statistical significance was defined at the $\mathrm{p}<.05$ level. An overall analysis was computed across the six items of Principal as Resource Provider, eleven items in the second section, Principal Interaction with Teachers and the ten items in the third section, Principal Assurance of School Climate Conductive to Literacy. This analysis was conducted in order to detect patterns or potential difference in the ratings of the two groups of principals. As with the individual item analyses, the independent variable was Reading First versus non-Reading First. In this analysis, however, the dependent variable was the mean (average) of the principal ratings of the questions.

\section{Research Question 2.}

Does the reading-instructional-leadership professional development of principals differ in Reading First Schools versus non-Reading First Schools?

Section 4 of the survey instrument (Professional Development) involved measurement of principal education and training using a yes or no response. In Research Question 2, a chi-square compared the variables. The effects of the two variables differed significantly. 


\section{Research Question 3.}

Is there a difference in Reading/Language Arts WESTEST scores for the years 2005, 2006 and 2007 for third grade students in Reading First versus non-Reading First Schools?

This research question was tested for (a) All Students, (b) Students Economically Disadvantaged subgroup (low SES), and (c) Students with Disabilities subgroup (SPED). Statistics employed in analyzing these three parts of Research Question 3 included Mean $(M)$, Standard Deviation (SD), Analysis of Variance (ANOVA, $F$ ), and $t$-Test $(t)$. Ultimately, the test addresses the cumulative impact of the program on student achievement, both between groups (Reading First versus non-Reading First schools) and within groups (WESTEST Reading/Language Arts for All Students in 2005, 2006, and 2007). In order to complete the research question, data was needed for 3 years: 2005, 2006, and 2007.

In addition, for the Research Questions 1, 2, and 3, on Section 5 of the survey, principal demographic data was considered. Each participant was asked to record the number of years in his or her current position, gender, years spent teaching reading, number of reading courses taken, number of years experience as principal at what level, and finally, the average time spent daily on instructional issues. This information is presented in tables of means and ranges as analyzed and used to present descriptive data in the survey results.

\section{Summary}

The overall research compared difference among principals‘ reading instructional leadership practices, professional development and students Reading/Language Arts test scores. This chapter described the procedure utilized in order to determine whether or not a relationship existed between principal practices, professional development, and student achievement scores. 
A self-reporting survey was distributed to 343 public elementary principals in West Virginia. Principals of non-Reading First Schools were selected using a random sampling procedure $(n=28)$, and Reading First Schools $(n=28)$, were considered a sub-group in the random sampling. Analyses for this study involved both descriptive and inferential statistics. In Research Question 1, means, standard deviations, and $t$-test were reported. In Research Question 2, chi-square compared whether the variables differ significantly were computed. In Research Question 3, mean scales and standard deviation for the outcomes, means, standard deviations and ANOVA were reported. Additionally, demographic data was considered. 


\section{CHAPTER IV: DATA ANALYSIS AND INTERPRETATION}

The purpose of this study was to examine the reading instructional leadership practices and professional development of 40 Reading First principals and 40 non-Reading First principals. There were 40 Reading First West Virginia K-5 public elementary principals, leaving 303 from which to select 40 non-Reading First West Virginia K-5 public elementary principals. The study also compares the percentage of students who scored mastery or above as measured by the third grade Reading/Language Arts West Virginia Educational Standards Test (WESTEST) in the years 2005, 2006, and 2007.

Chapter 4 provides a description and analysis of the data collected utilizing the Survey of Public Elementary Principals in West Virginia: Reading Instructional Leadership (see Appendix A). This chapter includes demographic statistics, provides data and key findings which address each of the study's three research questions, and concludes with a summary of the data.

This study had a population of each of the $343 \mathrm{~K}-5$ public elementary school principals in West Virginia. Survey results included the totality of the 40 Reading First principals, consisting of 28 respondent principals and 12 unresponsive. The 12 non-responsive contained 3 surveys which were returned by Survey Monkey as _opted out' and 1 survey which_baunced back. According to Survey Monkey, the 3 surveys reported as opting out were based on the established email account preferences of the respondents. These email addresses may possibly have blocked receipt of any information from Survey Monkey; therefore the response was not necessarily based on the principal's desire to not participate in this survey, rather an established preference of blocking electronic spam mail. This was identified as a limitation by the researcher in the collection of the electronic survey data. 
The non-Reading First school principals surveyed included a total of 303 K-5 public elementary school principals in West Virginia. Survey results included a total of 96 respondents and 207 non-responsive. The research results consisted of 28 principals that were randomly selected from the original 96. A simple random sampling process without replacement was used in choosing the 28 principals from the 96 schools. The book A Million Random Digits with 100,000 Normal Deviates, (Rand, 2002) was utilized in order to increase randomization of the selection. Each respondent of non-Reading First schools was assigned a three digit number. The researcher chose a random page number in A Million Random Digits with 100,000 Normal Deviates, on which the participants were selected. The 207 non-responsive contained 8 surveys which were returned by Survey Monkey as _opted out' and 15 surveys which bounced back." According to Survey Monkey, the surveys reported as opting out were based on the established email account preferences of the respondents. These email addresses may possibly have blocked receipt of any information from Survey Monkey; therefore the response was not necessarily based on the principal's desire to not participate in this survey, rather an established preference of blocking electronic spam mail. This was identified as a limitation by the researcher in the collection of the electronic survey data.

The final participant response rate with Reading First school principals was $70 \%$ or 28 of 40 participants. According to Suskie (1996) most professional researchers aspire for a $70 \%$ to $80 \%$ response rate and consider $50 \%$ minimally adequate.

\section{Demographic Information}

The demographic information regarding the population surveyed includes number of years in current position, number of years in Reading First school, principal gender, number of years teaching reading, number of reading courses taken, number of years as principal, number 
of years at each programmatic level, and number of hours invested in instruction daily. Results were calculated as mean scores for most items as shown in Table 3. The following Table 3 presents information about the principals and the schools. They are based on the 10 items in the Section 5 Demographic of the survey. 
Table 3

Demographic Information for Reading First and non-Reading First Principals

\begin{tabular}{|l|l|l|}
\hline Item & $\begin{array}{l}\text { Reading First } \\
(\mathrm{N}=28)\end{array}$ & $\begin{array}{l}\text { non-Reading First } \\
(\mathrm{N}=28)\end{array}$ \\
\hline $\begin{array}{l}\text { 40. Number of years in current position } \\
\text { (mean) }\end{array}$ & 4.78 & 6.39 \\
\hline $\begin{array}{l}\text { 41. Number of years in Reading First } \\
\text { school (mean) }\end{array}$ & 3.93 & $35.71 \%$ \\
\hline 42. Gender - Males & $53.57 \%$ & $64.29 \%$ \\
\hline 42. Gender - Females & $46.43 \%$ & 9.36 \\
\hline $\begin{array}{l}\text { 43. Number of years taught reading } \\
\text { (mean) }\end{array}$ & 5.71 & 3.25 \\
\hline 44. Number of reading courses (mean) & 1.75 & 9.54 \\
\hline $\begin{array}{l}\text { 45. Number of years as a principal } \\
\text { (mean) }\end{array}$ & 8.25 & 15.11 \\
\hline $\begin{array}{l}\text { 46. Number of years at elementary level } \\
\text { (mean) }\end{array}$ & 12.39 & 6.39 \\
\hline $\begin{array}{l}\text { 47. Number of years at middle school } \\
\text { level (mean) }\end{array}$ & 8.18 & 2.43 \\
\hline $\begin{array}{l}\text { 48. Number of years at high school level } \\
\text { (mean) }\end{array}$ & 2.86 & 71.43 \\
\hline $\begin{array}{l}\text { 49. Number hours of day spent working } \\
\text { with instruction (mean) }\end{array}$ & 2.60 & 2.50 \\
\hline 50. Drawing for gift certificate (mean) & 82.14 & \\
\hline
\end{tabular}

Demographic results indicate non-Reading First principals had served in their current positions longer, 6.39 years compared to 4.78 years. The average number of years for Reading First principals in their positions was 3.93. This is interesting to note, considering the Reading First program was 6 years in duration. This could possibly indicate a high turnover rate. In Reading First schools, there were more males (53.5\%) than females (35.71\%). However, in non-Reading First schools, more females (64.2\%) than males (46.43\%) were serving as principals. 
The data reveal that prior to their principalship, non-Reading First principals had a greater number of years experience teaching reading. The non-Reading First principals had 9.36 years teaching reading compared to the Reading First 5.71 years. Additionally, in the survey question regarding the number of reading courses the non-Reading First principals demonstrated a greater number, non-Reading First principal (3.25), compared to the Reading First (1.75) reading courses. It is interesting to note that the non-Reading First principals demonstrate knowledge of reading based on the number of courses and years teaching reading that would enable them to be reading instructional leaders.

Demographic data reveal that the non-Reading First principals had a higher mean of (9.54) number of years as a principal compared to the Reading First (8.25). The non-Reading First principal had more experience at the elementary level (15.11) than did their Reading First (12.39) counterparts. However, the Reading First had a higher number of years (8.18) at middle school level compared to the non-Reading First (6.39). At the high school level the Reading First (2.86) had a greater number of years experience than non-Reading First (2.43) principals. Demographic data also reveals that Reading First principals spent 2.60 hours daily working with instruction compared to the non-Reading First 2.50 hours.

The survey instrument included a total of 50 questions. The questions were divided into 5 Sections. Section 1 includes 6 questions regarding Principal as a Resource Provider. Section 2 of the survey includes 11 questions relating to the Principal Interaction with Teachers. Section 3 contains 10 questions relating to Principal Assurance of School Climate Conducive to Literacy Development. Section 4 includes 12 questions concerning skills and information regarding Principal Professional Development resources and experiences. Section 5 includes 10 questions 
regarding demographic information. The final is a yes/no question that queries respondents concerning their desire to enter the drawing for survey participation.

\section{Research Questions}

\section{Research Question 1.}

Research Question 1: Do the reading instructional leadership practices of principals differ in Reading First Schools versus non-Reading First Schools?

This research question was tested through responses to 26 items in three sections. There are six items in the first section, Principal as Resource provider. There are eleven items in the second section, Principal Interaction with teachers. There are ten items in the third section, Principal Assurance of School Climate Conductive to Literacy Development. A $t$-test was computed for each of the items to determine if the Reading First principals $(n=28)$ rated the items different from the non-Reading First principals $(n=28)$.

\section{Provider Principal as Resource.}

To assess potential differences in the ratings of the two groups of principals, a $t$-test was computed for each of the six items. Statistical significance was defined at the $\mathrm{p}<.05$ level. These statistical test results are presented in Table 4 through Table 9. The results are presented in the following paragraphs.

A $t$-test was calculated for each of the six items in Principal as Resource Provider. Table 4 reveals data that the principal provides funding to build classroom libraries." A $t$-test was calculated. 
Table 4

Question 1: Provides funding to build classroom libraries

\begin{tabular}{|l|l|l|l|l|l|l|}
\hline Group & $\mathrm{N}$ & Mean & Difference & $\begin{array}{l}\text { Standard } \\
\text { Deviation }\end{array}$ & $t$ & $\begin{array}{l}\text { Significance } \\
*\end{array}$ \\
\hline $\begin{array}{l}\text { Reading } \\
\text { First }\end{array}$ & 28 & 2.96 & .10 & 1.036 & .373 & .711 \\
\hline $\begin{array}{l}\text { non- } \\
\text { Reading } \\
\text { First }\end{array}$ & 28 & 2.86 & & 1.113 & & \\
\hline
\end{tabular}

As indicated by Table 4, the data in Item 1, provides funding to build classroom libraries," did not yield a significant finding. Also note that the mean is somewhat higher in Reading First principals than non-Reading First principals.

Table 5 reveals data that the principal provides resources for Tier II and Tier III Interventions." A $t$-test was calculated.

Table 5

Question 2: Provides resources for Tier II and Tier III Interventions

\begin{tabular}{|l|l|l|l|l|l|l|}
\hline Group & $\mathrm{N}$ & Mean & Difference & $\begin{array}{l}\text { Standard } \\
\text { Deviation }\end{array}$ & $t$ & $\begin{array}{l}\text { Significance } \\
*\end{array}$ \\
\hline $\begin{array}{l}\text { Reading } \\
\text { First }\end{array}$ & 28 & 3.68 & .11 & .548 & .590 & .558 \\
\hline $\begin{array}{l}\text { non- } \\
\text { Reading } \\
\text { First }\end{array}$ & 28 & 3.57 & & .790 & & \\
\hline
\end{tabular}

As indicated by Table 5, the data in Item 2, provides resources for Tier II and Tier III interventions," did not yield a significant finding. Also note that the mean is somewhat higher in Reading First principals than non-Reading First principals.

Table 6 reveals data that the principal facilitates professional development for teachers." A $t$-test was calculated. 
Table 6

Question 3: Facilitates professional development for teachers

\begin{tabular}{|l|l|l|l|l|l|l|}
\hline Group & $\mathrm{N}$ & Mean & Difference & $\begin{array}{l}\text { Standard } \\
\text { Deviation }\end{array}$ & $t$ & $\begin{array}{l}\text { Significance } \\
*\end{array}$ \\
\hline $\begin{array}{l}\text { Reading } \\
\text { First }\end{array}$ & 28 & 3.75 & .64 & .690 & 2.146 & $.036^{*}$ \\
\hline $\begin{array}{l}\text { non- } \\
\text { Reading } \\
\text { First }\end{array}$ & 27 & 3.11 & & .692 & & \\
\hline
\end{tabular}

As indicated by Table 6, the data in Item 3, facilitates for professional development for teachers (100 hours annually)," yielded a statistically significant difference in which the Reading First principals rated this item higher than the non-Reading First Principals, $t=2.146, p=.036$.

Table 7 reveals data that the principal provides opportunities for teachers to attend conferences and trainings." A $t$-test was calculated.

Table 7

Question 4: Provides opportunities for teachers to attend conferences and trainings

\begin{tabular}{|l|l|l|l|l|l|l|}
\hline Group & $\mathrm{N}$ & Mean & Difference & $\begin{array}{l}\text { Standard } \\
\text { Deviation }\end{array}$ & $t$ & $\begin{array}{l}\text { Significance } \\
*\end{array}$ \\
\hline $\begin{array}{l}\text { Reading } \\
\text { First }\end{array}$ & 28 & 3.79 & .54 & .418 & 3.687 & $.001^{*}$ \\
\hline $\begin{array}{l}\text { non- } \\
\text { Reading } \\
\text { First }\end{array}$ & 28 & 3.25 & & .645 & & \\
\hline
\end{tabular}

As indicated by Table 7 , the data in Item 4 provides opportunities for teachers to attend conferences and trainings," yields a statistically significant difference in which the Reading First principals rated this item higher than the non-Reading First Principals, $t=3.687, p=.001$.

Table 8 reveals data that the principal provides on-going follow-up training/professional development." A $t$-test was calculated. 
Table 8

Question 5: Provides on-going follow-up training/professional development

\begin{tabular}{|l|l|l|l|l|l|l|}
\hline Group & $\mathrm{N}$ & Mean & Difference & $\begin{array}{l}\text { Standard } \\
\text { Deviation }\end{array}$ & $t$ & $\begin{array}{l}\text { Significance } \\
*\end{array}$ \\
\hline $\begin{array}{l}\text { Reading } \\
\text { First }\end{array}$ & 28 & 3.68 & .32 & .476 & 1.950 & .057 \\
\hline $\begin{array}{l}\text { non- } \\
\text { Reading } \\
\text { First }\end{array}$ & 28 & 3.36 & & .731 & & \\
\hline
\end{tabular}

As indicated by Table 8, the data in Item 5 provides on-going follow-up training/professional development," did not yield a significant finding. Although there was no significant finding the data yielded a strong trend toward statistical significance in which the Reading First principals tend to rate this item higher than the non-Reading First principals, $t=1.950, p=.057$.

Table 9 reveals data that the principal facilitates standardized test data analysis with teachers." A $t$-test was calculated.

Table 9

Question 6: Facilitates standardized test data analysis with teachers

\begin{tabular}{|l|l|l|l|l|l|l|}
\hline Group & $\mathrm{N}$ & Mean & Difference & $\begin{array}{l}\text { Standard } \\
\text { Deviation }\end{array}$ & $t$ & $\begin{array}{l}\text { Significance } \\
*\end{array}$ \\
\hline $\begin{array}{l}\text { Reading } \\
\text { First }\end{array}$ & 28 & 3.82 & .03 & .390 & .274 & .785 \\
\hline $\begin{array}{l}\text { non- } \\
\text { Reading } \\
\text { First }\end{array}$ & 28 & 3.79 & & .568 & & \\
\hline
\end{tabular}

As indicated by Table 9, the data in Item 6, facilitates standardized test data analysis with teachers," did not yield a significant finding. Also note that the mean is somewhat higher in Reading First principals than non-Reading First principals.

An overall analysis was computed across the six items of Principal as Resource Provider shown in Table 10. This analysis was conducted in order to detect patterns or potential 
differences in the ratings of the two groups of principals. As with the individual item analyses, the independent variable was Reading First versus non-Reading First. In this analysis, however, the dependent variable was the mean (average) of the principal ratings of the six questions. Also a $t$-test for the six item totals (mean per participant) was computed.

Table 10

Principal as Resource Provider (Items 1-6)

\begin{tabular}{|l|l|l|l|l|l|l|}
\hline Group & $\mathrm{N}$ & Mean & Difference & $\begin{array}{l}\text { Standard } \\
\text { Deviation }\end{array}$ & $t$ & $\begin{array}{l}\text { Significance } \\
*\end{array}$ \\
\hline $\begin{array}{l}\text { Reading } \\
\text { First }\end{array}$ & 28 & 3.58 & .24 & .401 & 2.008 & $.05^{*}$ \\
\hline $\begin{array}{l}\text { non- } \\
\text { Reading } \\
\text { First }\end{array}$ & 28 & 3.34 & & .502 & & \\
\hline
\end{tabular}

As indicated by Table 10 the data reveal this analysis yielded a statistically significant difference. This is important to note because the results indicate that Reading First principals scored higher in the area of Principal as Resource Provider. The 28 Reading First principals had a higher overall mean rating than the non-Reading First principals, $t=2.008, p=.05$.

Additionally, it is interesting to note that Reading First Principals had a higher mean for each of the six items in the category of Principal as Resource Provider questions than the nonReading First Principal. This relationship is illustrated in Table 11. 
Table 11

Principal as Resource Provider, High/Low Response (Items 1-6)

\begin{tabular}{|l|l|l|}
\hline Question & Reading First & Non-Reading First \\
\hline 1 & Higher & Lower \\
\hline 2 & Higher & Lower \\
\hline $3 \quad \mathrm{~S}$ & Higher & Lower \\
\hline $4 \mathrm{~S}$ & Higher & Lower \\
\hline $5 \mathrm{~T}$ & Higher & Lower \\
\hline 6 & Higher & Lower \\
\hline
\end{tabular}

$\mathrm{S}=$ Significant, $\mathrm{T}=$ Trend

As indicated in Table 11, Reading First Principals had a higher mean for each of the six items in the category of Principal as Resource Provide questions than the non-Reading First Principal. The results for this figure were derived through an evaluation of the means for each item (1-6) under the Principal as Resource Provider. Table 11 illustrates the non-Reading First principal as scoring lower on each of the six items. However, it should be noted, based on the $t$-test results that Questions 3 and 4 yielded a $\mathrm{p}<.05$ significant finding, and Question 5 produced a strong trend.

Principal Interaction with Teacher.

To assess potential differences in the ratings of the two groups of principals, a $t$-test was computed for each of the ten items. Statistical significance was defined at the $p<.05$ level.

These statistical test results are presented in Tables 12 through Table 21 (illustrating items 7 through 17, with the exception of item 13 which is an unintentional duplicate of number 12 , therefore was omitted). The results are presented in the following paragraphs.

A $t$-test was calculated for each of the ten items in Principal Interaction with Teachers. Also a $t$ test for the ten item totals (mean per participant) was computed. Table 12 reveals data that the 
principal —shæs information with faculty to keep them aware of what is happening." A $t$-test was calculated.

Table 12

Question 7: Shares information with faculty to keep them aware of what is happening

\begin{tabular}{|l|l|l|l|l|l|l|}
\hline Group & $\mathrm{N}$ & Mean & Difference & $\begin{array}{l}\text { Standard } \\
\text { Deviation }\end{array}$ & $t$ & $\begin{array}{l}\text { Significance } \\
*\end{array}$ \\
\hline $\begin{array}{l}\text { Reading } \\
\text { First }\end{array}$ & 28 & 3.93 & -.03 & .262 & -.585 & .561 \\
\hline $\begin{array}{l}\text { non- } \\
\text { Reading } \\
\text { First }\end{array}$ & 28 & 3.96 & & .189 & & \\
\hline
\end{tabular}

As indicated by Table 12, the data in Item 7, -shares information with faculty to keep them aware of what is happening," did not yield a significant finding. Also note that the mean is somewhat higher in non-Reading First principals than Reading First principals.

Table 13 reveals data that the principal participates in analysis of reading assessment/data/instructional decisions." A $t$-test was calculated.

Table 13

Question 8: Participates in analysis of reading assessment/data/instructional decisions

\begin{tabular}{|l|l|l|l|l|l|l|}
\hline Group & $\mathrm{N}$ & Mean & Difference & $\begin{array}{l}\text { Standard } \\
\text { Deviation }\end{array}$ & $t$ & $\begin{array}{l}\text { Significance } \\
*\end{array}$ \\
\hline $\begin{array}{l}\text { Reading } \\
\text { First }\end{array}$ & 28 & 3.79 & -.07 & .418 & -.617 & .116 \\
\hline $\begin{array}{l}\text { non- } \\
\text { Reading } \\
\text { First }\end{array}$ & 28 & 3.86 & & .448 & & \\
\hline
\end{tabular}

As indicated by Table 13 the data in Item 8, participates in analysis of reading assessment/data/instructional decisions," did not yield a significant finding. Also note that the mean is somewhat higher in non-Reading First principals than Reading First principals.

Table 14 reveals data that the principal interacts informally regarding curriculum and instruction." A $t$-test was calculated. 
Table 14

Question 9: Interacts informally regarding curriculum and instruction

\begin{tabular}{|l|l|l|l|l|l|l|}
\hline Group & $\mathrm{N}$ & Mean & Difference & $\begin{array}{l}\text { Standard } \\
\text { Deviation }\end{array}$ & $t$ & $\begin{array}{l}\text { Significance } \\
*\end{array}$ \\
\hline $\begin{array}{l}\text { Reading } \\
\text { First }\end{array}$ & 28 & 3.79 & 0 & .418 & .000 & 1.000 \\
\hline $\begin{array}{l}\text { non- } \\
\text { Reading } \\
\text { First }\end{array}$ & 28 & 3.79 & & .448 & & \\
\hline
\end{tabular}

As indicated by Table 14, the data in Item 9, -interacts informally regarding curriculum and instruction," did not yield a significant finding. Also note that the mean is the same for Reading First principals and non-Reading First principals.

Table 15 reveals data that the principal - checks lesson plans and provides feedback regarding reading instruction.” A $t$-test was calculated.

Table 15

Question 10: Checks lesson plans and provides feedback regarding reading instruction

\begin{tabular}{|l|l|l|l|l|l|l|}
\hline Group & $\mathrm{N}$ & Mean & Difference & $\begin{array}{l}\text { Standard } \\
\text { Deviation }\end{array}$ & $t$ & $\begin{array}{l}\text { Significance } \\
*\end{array}$ \\
\hline $\begin{array}{l}\text { Reading } \\
\text { First }\end{array}$ & 27 & 3.81 & .27 & .396 & 2.1 & .133 \\
\hline $\begin{array}{l}\text { non- } \\
\text { Reading } \\
\text { First }\end{array}$ & 28 & 3.54 & & .576 & & \\
\hline
\end{tabular}

As indicated by Table 15, the data in Item 10, -ehecks lessons plans and provides feedback regarding reading instruction," did not yield a significant finding. Also note that the mean is somewhat higher in Reading First principals than non-Reading First principals.

Table 16 reveals data that the principal «ses observation walk-through for reading to ensure reading instruction is occurring in all classrooms at grade levels." A $t$-test was calculated. 
Table 16

Question 11: Uses observation walk-through for reading to ensure reading instruction is occurring in all classrooms at grade levels

\begin{tabular}{|l|l|l|l|l|l|l|}
\hline Group & $\mathrm{N}$ & Mean & Difference & $\begin{array}{l}\text { Standard } \\
\text { Deviation }\end{array}$ & $t$ & $\begin{array}{l}\text { Significance } \\
*\end{array}$ \\
\hline $\begin{array}{l}\text { Reading } \\
\text { First }\end{array}$ & 27 & 3.63 & -.01 & .492 & -.087 & .151 \\
\hline $\begin{array}{l}\text { non- } \\
\text { Reading } \\
\text { First }\end{array}$ & 28 & 3.64 & & .621 & & \\
\hline
\end{tabular}

As indicated by Table 16, the data in Item 11, «ses Observation Walk-Through for Reading to ensure reading instruction is occurring in all classrooms at all grade levels," did not yield a significant finding. Also note that the mean is somewhat higher in non-Reading First principals than Reading First principals.

Table 17 reveals data that the principal participates in interviewing and hiring of new teachers." A $t$-test was calculated.

Table 17

Question 12: Participates in interviewing and hiring of new teachers

\begin{tabular}{|l|l|l|l|l|l|l|}
\hline Group & $\mathrm{N}$ & Mean & Difference & $\begin{array}{l}\text { Standard } \\
\text { Deviation }\end{array}$ & $t$ & $\begin{array}{l}\text { Significance } \\
*\end{array}$ \\
\hline $\begin{array}{l}\text { Reading } \\
\text { First }\end{array}$ & 28 & 3.46 & .25 & .881 & 1.091 & .229 \\
\hline $\begin{array}{l}\text { non- } \\
\text { Reading } \\
\text { First }\end{array}$ & 28 & 3.21 & & .833 & & \\
\hline
\end{tabular}

As indicated by Table 17, the data in Item 12, participates in interviewing and hiring of new teachers," did not yield a significant finding. Also note that the mean is somewhat higher in Reading First principals than non-Reading First principals. 
Table 18 reveals data that the principal tistens to children read frequently (time is spent on weekly basis listening to children read).” A $t$-test was calculated.

Table 18

Question 14: Listens to children read frequently (time is spent on weekly basis listening to children read)

\begin{tabular}{|l|l|l|l|l|l|l|}
\hline Group & $\mathrm{N}$ & Mean & Difference & $\begin{array}{l}\text { Standard } \\
\text { Deviation }\end{array}$ & $t$ & $\begin{array}{l}\text { Significance } \\
*\end{array}$ \\
\hline $\begin{array}{l}\text { Reading } \\
\text { First }\end{array}$ & 28 & 2.79 & .11 & .686 & .591 & .557 \\
\hline $\begin{array}{l}\text { non- } \\
\text { Reading } \\
\text { First }\end{array}$ & 28 & 2.68 & & .670 & & \\
\hline
\end{tabular}

As indicated by Table 18, the data in Item 14, tistens to children read frequently (time is spent on a weekly basis listening to children read," did not yield a significant finding. Also note that the mean is somewhat higher in Reading First principals than non-Reading First principals.

Table 19 reveals that the principal -aads to students frequently (time is spent on a weekly basis reading to children)." A $t$-test was calculated.

Table 19

Question 15: Reads to students frequently (time is spent on a weekly basis reading to children)

\begin{tabular}{|l|l|l|l|l|l|l|}
\hline Group & $\mathrm{N}$ & Mean & Difference & $\begin{array}{l}\text { Standard } \\
\text { Deviation }\end{array}$ & $t$ & $\begin{array}{l}\text { Significance } \\
*\end{array}$ \\
\hline $\begin{array}{l}\text { Reading } \\
\text { First }\end{array}$ & 28 & 2.61 & .29 & .629 & 1.578 & .120 \\
\hline $\begin{array}{l}\text { non- } \\
\text { Reading } \\
\text { First }\end{array}$ & 28 & 2.32 & & .723 & & \\
\hline
\end{tabular}

As indicated by Table 19, the data in Item 15, reads to students frequently (time is spent on a weekly basis reading to children)," did not yield a significant finding. Also note that the mean is somewhat higher in Reading First principals than non-Reading First principals. 
Table 20 reveals data that the principal interacts informally with students." A $t$-test was calculated.

Table 20

Question 16: Interacts informally with students

\begin{tabular}{|l|l|l|l|l|l|l|}
\hline Group & $\mathrm{N}$ & Mean & Difference & $\begin{array}{l}\text { Standard } \\
\text { Deviation }\end{array}$ & $t$ & $\begin{array}{l}\text { Significance } \\
*\end{array}$ \\
\hline $\begin{array}{l}\text { Reading } \\
\text { First }\end{array}$ & 28 & 3.93 & 0 & .262 & 0 & .100 \\
\hline $\begin{array}{l}\text { non- } \\
\text { Reading } \\
\text { First }\end{array}$ & 28 & 3.93 & & .262 & & \\
\hline
\end{tabular}

As indicated by Table 20, the data in Item 16, interacts informally with students," did not yield a significant finding. Also note that the mean is the same for Reading First principals and nonReading First principals.

Table 21 reveals that the principal - povides opportunities for celebration in forms of prizes, awards, or stunts." A $t$-test was calculated.

Table 21

Question 17: Provides opportunities for celebration in forms of prizes, awards, or stunts

\begin{tabular}{|l|l|l|l|l|l|l|}
\hline Group & $\mathrm{N}$ & Mean & Difference & $\begin{array}{l}\text { Standard } \\
\text { Deviation }\end{array}$ & $t$ & $\begin{array}{l}\text { Significance } \\
*\end{array}$ \\
\hline $\begin{array}{l}\text { Reading } \\
\text { First }\end{array}$ & 28 & 3.50 & .29 & .509 & -2.295 & $.026^{*}$ \\
\hline $\begin{array}{l}\text { non- } \\
\text { Reading } \\
\text { First }\end{array}$ & 28 & 3.79 & & .418 & & \\
\hline
\end{tabular}

As indicated by Table 21, the data in Item 17, provides opportunities for celebration in forms of prizes, awards, or stunts," did yield a statistically significant difference. The non-Reading First principals rated this item higher than the Reading First principals, $t=-2.295, p=.026$. 
Table 22 is an overall analysis across the ten items of Principal Interaction with Teachers. As with the individual item analyses, the independent variable was Reading First versus nonReading First. In this analysis, however, the dependent variable was the mean (average) of the ten questions (ratings) by the principals.

Table 22

Principal Interaction with Teachers (Items 7-17)

\begin{tabular}{|l|l|l|l|l|l|l|}
\hline Group & $\mathrm{N}$ & Mean & Difference & $\begin{array}{l}\text { Standard } \\
\text { Deviation }\end{array}$ & $t$ & $\begin{array}{l}\text { Significance } \\
*\end{array}$ \\
\hline $\begin{array}{l}\text { Reading } \\
\text { First }\end{array}$ & 28 & 3.22 & .09 & .250 & 1.35 & .182 \\
\hline $\begin{array}{l}\text { non- } \\
\text { Reading } \\
\text { First }\end{array}$ & 28 & 3.13 & .270 & & \\
\hline
\end{tabular}

As indicated by Table 22 the data did not yield a statistically significant difference. The 28

Reading First principals did have a somewhat higher overall mean rating than the non-Reading First principals, $t=1.35, p=.182$, however, it was not statistically significant.

Additionally, it is interesting to note that each of the two types of principals, Reading First and non-Reading First, demonstrate relatively equal findings in regard to the ten items in the category of Principal Interaction with Teachers. This relationship is illustrated in Table 23. This is important to note because the results indicate that Reading First and non-Reading First principals had similar scores in the area of Principal Interaction with Teachers. Reading First principals scored higher on 4 items, non-Reading First scored higher on 4 items, and each tied on 2 items. 
Table 23

Principal Interactions with Teachers, Low/High (Items 7-17)

\begin{tabular}{|l|l|l|}
\hline Question & Reading First & Non-Reading First \\
\hline 7 & Lower & Higher \\
\hline 8 & Lower & Higher \\
\hline 9 & Tied & Tied \\
\hline 10 & Higher & Lower \\
\hline 11 & Lower & Higher \\
\hline 12 & Higher & Lower \\
\hline 14 & Higher & Lower \\
\hline 15 & Higher & Lower \\
\hline 16 & Tied & Tied \\
\hline $17 \quad \mathrm{~S}$ & Lower & Higher \\
\hline
\end{tabular}

S=Significant

As indicated in Table 23 each of the two types of principals, Reading First and non-Reading

First, demonstrated a relatively equal mean in regard to the ten items in the category of Principal Interaction with Teachers.

Principal Assurance of School Climate Conducive to Literacy Development.

To assess potential differences in the ratings of the two groups of principals, a $t$-test was computed for each of the ten items. Statistical significance was defined at the $\mathrm{p}<.05$ level. These statistical test results are presented in Table 24 through Table 33. The results are presented in the following paragraphs.

A $t$-test was also calculated for each of the ten items in Principal Assurance of School Climate Conducive to Literacy Development. Also, a $t$-test for the ten item totals (means per participant) was computed. 
Table 24 reveals data that the principal protects the 90/120 minute reading block." A $t$ test was calculated.

Table 24

Question 18: Protects the 90/120 minute reading block

\begin{tabular}{|l|l|l|l|l|l|l|}
\hline Group & $\mathrm{N}$ & Mean & Difference & $\begin{array}{l}\text { Standard } \\
\text { Deviation }\end{array}$ & $t$ & $\begin{array}{l}\text { Significance } \\
*\end{array}$ \\
\hline $\begin{array}{l}\text { Reading } \\
\text { First }\end{array}$ & 28 & 4.00 & 0 & .000 & & \\
\hline $\begin{array}{l}\text { Non } \\
\text { Reading } \\
\text { First }\end{array}$ & 28 & 4.00 & .000 & & \\
\hline
\end{tabular}

As indicated by Table 24, the data in Item 18, protects the 90/120 minute reading block," did not yield a significant finding. Also note that the mean is the same for Reading First principals and non-Reading First principals.

Table 25 reveals data that the principal -supports special activities that focus on instructional goals tested on the WESTEST." A $t$ - test was calculated.

Table 25

Question 19: Supports special activities that focus on instructional goals tested on the WESTEST

\begin{tabular}{|l|l|l|l|l|l|l|}
\hline Group & $\mathrm{N}$ & Mean & Difference & $\begin{array}{l}\text { Standard } \\
\text { Deviation }\end{array}$ & $t$ & $\begin{array}{l}\text { Significance } \\
*\end{array}$ \\
\hline $\begin{array}{l}\text { Reading } \\
\text { First }\end{array}$ & 28 & 3.71 & .32 & .460 & 1.957 & .057 \\
\hline $\begin{array}{l}\text { non- } \\
\text { Reading } \\
\text { First }\end{array}$ & 28 & 3.39 & & .737 & & \\
\hline
\end{tabular}

As indicated by Table 25, the data revealed in Item 19, - suppats special activities that focus on instructional goals tested on the WESTEST," did not yield a significant finding. Although there 
was no significant finding, the data yielded a strong trend toward statistical significance in which the Reading First principals tend to rate this item higher than the non-Reading First principals, $t=1.950, p=.057$.

Table 26 reveals data that the principal -supports reading/literature courses for students in all grades." A $t$-test was calculated.

Table 26

Question 20: Supports reading/literature courses for students in all grades

\begin{tabular}{|l|l|l|l|l|l|l|}
\hline Group & $\mathrm{N}$ & Mean & Difference & $\begin{array}{l}\text { Standard } \\
\text { Deviation }\end{array}$ & $t$ & $\begin{array}{l}\text { Significance } \\
*\end{array}$ \\
\hline $\begin{array}{l}\text { Reading } \\
\text { First }\end{array}$ & 27 & 3.70 & -.09 & .465 & -.520 & .607 \\
\hline $\begin{array}{l}\text { non- } \\
\text { Reading } \\
\text { First }\end{array}$ & 28 & 3.79 & & .686 & & \\
\hline
\end{tabular}

As indicated by Table 26, the data in Item 20 -supports reading/literature courses for students in all grades," did not yield a significant finding. Also note that the mean is somewhat higher for non-Reading First principals than Reading First principals.

Table 27 reveals data that the principal -supports Tier II/Tier III for students.” A $t$-test was calculated.

Table 27

Question 21: Supports Tier II/Tier III for students

\begin{tabular}{|l|l|l|l|l|l|l|}
\hline Group & $\mathrm{N}$ & Mean & Difference & $\begin{array}{l}\text { Standard } \\
\text { Deviation }\end{array}$ & $t$ & $\begin{array}{l}\text { Significance } \\
*\end{array}$ \\
\hline $\begin{array}{l}\text { Reading } \\
\text { First }\end{array}$ & 28 & 4.00 & .14 & .000 & 1.279 & .212 \\
\hline $\begin{array}{l}\text { non- } \\
\text { Reading } \\
\text { First }\end{array}$ & 28 & 3.86 & & .591 & & \\
\hline
\end{tabular}


As indicated by Table 27, the data in Item 21, -supports tier II/Tier III for students," did not yield a significant finding. Also note that the mean is somewhat higher in Reading First principals than non-Reading First principals.

Table 28 reveals data that the principal -supports peer/parent tutoring programs." A $t$ test was calculated.

Table 28

Question 22: Supports peer/parent tutoring programs

\begin{tabular}{|l|l|l|l|l|l|l|}
\hline Group & $\mathrm{N}$ & Mean & Difference & $\begin{array}{l}\text { Standard } \\
\text { Deviation }\end{array}$ & $t$ & $\begin{array}{l}\text { Significance } \\
*\end{array}$ \\
\hline $\begin{array}{l}\text { Reading } \\
\text { First }\end{array}$ & 28 & 3.14 & .14 & .651 & 1.532 & .487 \\
\hline $\begin{array}{l}\text { non- } \\
\text { Reading } \\
\text { First }\end{array}$ & 28 & 3.00 & & .861 & & \\
\hline
\end{tabular}

As indicated by Table 28, the data in Item 22, -supports peer/Parent tutoring programs," did not yield a significant finding. Also note that the mean is somewhat higher in Reading First principals than non-Reading First principals.

Table 29 reveals data that the principal -supports interaction among faculty." A $t$-test was calculated. 
Table 29

Question 23: Supports interaction among faculty

\begin{tabular}{|l|l|l|l|l|l|l|}
\hline Group & $\mathrm{N}$ & Mean & Difference & $\begin{array}{l}\text { Standard } \\
\text { Deviation }\end{array}$ & $t$ & $\begin{array}{l}\text { Significance } \\
*\end{array}$ \\
\hline $\begin{array}{l}\text { Reading } \\
\text { First }\end{array}$ & 28 & 3.79 & -.14 & .418 & -1.532 & .132 \\
\hline $\begin{array}{l}\text { non- } \\
\text { Reading } \\
\text { First }\end{array}$ & 28 & 3.93 & & .262 & & \\
\hline
\end{tabular}

As indicated by Table 29, the data in Item 23, -supports interaction among faculty," did not yield a significant finding. Also note that the mean is somewhat higher in non- Reading First principals than Reading First principals.

Table30 reveals data that the principal -supports displays of student work in classrooms and halls." A $t$-test was calculated.

Table 30

Question 24: Supports displays of student work in classrooms and halls

\begin{tabular}{|l|l|l|l|l|l|l|}
\hline Group & N & Mean & Difference & $\begin{array}{l}\text { Standard } \\
\text { Deviation }\end{array}$ & $t$ & $\begin{array}{l}\text { Significance } \\
*\end{array}$ \\
\hline $\begin{array}{l}\text { Reading } \\
\text { First }\end{array}$ & 28 & 3.86 & .07 & .356 & .688 & .494 \\
\hline $\begin{array}{l}\text { non- } \\
\text { Reading } \\
\text { First }\end{array}$ & 28 & 3.79 & & .418 & & \\
\hline
\end{tabular}

As indicated by Table 30, the data in Item 24, -supports display student work in classrooms and halls," did not yield a significant finding. Also note that the mean is somewhat higher for the Reading First principals than non-Reading First principals.

Table 31 reveals data that the principal -supports voluntary reading by students upon task completion." A $t$-test was calculated. 
Table 31

Question 25: Supports voluntary reading by students upon task completion

\begin{tabular}{|l|l|l|l|l|l|l|}
\hline Group & $\mathrm{N}$ & Mean & Difference & $\begin{array}{l}\text { Standard } \\
\text { Deviation }\end{array}$ & $t$ & $\begin{array}{l}\text { Significance } \\
*\end{array}$ \\
\hline $\begin{array}{l}\text { Reading } \\
\text { First }\end{array}$ & 28 & 3.46 & 0 & .576 & .000 & 1.000 \\
\hline $\begin{array}{l}\text { non- } \\
\text { Reading } \\
\text { First }\end{array}$ & 28 & 3.46 & & .793 & \\
\hline
\end{tabular}

As indicated by Table 31 , the data in Item 25, -supports voluntary reading by students upon task completion," did not yield a significant finding. Also note that the mean is the same for the Reading First and non-Reading First principals.

Table 32 reveals data that the principal -supports reading to students by guests/parents." A $t$-test was calculated.

Table 32

Question 26: Supports reading to students by guests/parents

\begin{tabular}{|l|l|l|l|l|l|l|}
\hline Group & $\mathrm{N}$ & Mean & Difference & $\begin{array}{l}\text { Standard } \\
\text { Deviation }\end{array}$ & $t$ & $\begin{array}{l}\text { Significance } \\
*\end{array}$ \\
\hline $\begin{array}{l}\text { Reading } \\
\text { First }\end{array}$ & 28 & 3.21 & .10 & .499 & .669 & .506 \\
\hline $\begin{array}{l}\text { non- } \\
\text { Reading } \\
\text { First }\end{array}$ & 28 & 3.11 & & & & \\
\hline
\end{tabular}

As indicated by Table 32, the data in Item 26, -supports reading to student by guests/parents," did not yield a significant finding. Also note that the mean is higher for the Reading First principals than non-Reading First. 
Table 33 reveals data that the principal assures school/classroom incentive programs for reading." A $t$-test was calculated.

Table 33

Question 27: Assures school/classroom incentive programs for reading

\begin{tabular}{|l|l|l|l|l|l|l|}
\hline Group & $\mathrm{N}$ & Mean & Difference & $\begin{array}{l}\text { Standard } \\
\text { Deviation }\end{array}$ & $t$ & $\begin{array}{l}\text { Significance } \\
*\end{array}$ \\
\hline $\begin{array}{l}\text { Reading } \\
\text { First }\end{array}$ & 28 & 3.39 & -.31 & .629 & -1.961 & .055 \\
\hline $\begin{array}{l}\text { non- } \\
\text { Reading } \\
\text { First }\end{array}$ & 27 & 3.70 & & .542 & \\
\hline
\end{tabular}

As indicated by Table 33, the data in Item 27, assures school/classroom incentive programs for reading," did not yield a significant finding. Although there was no significant finding, the data yielded a strong trend toward statistical significance in which the non- Reading First principals tend to rate this item higher than the Reading First principals, $t=-1.961, p=.055$.

Table 34 is an overall analysis across the ten items of Principal Assurance of School Climate Conducive to Literacy Development was computed. As with the individual item analyses, the independent variable was Reading First versus non-Reading First. In this analysis, however, the dependent variable was the mean (average) of the ten questions (ratings) by the principals. This is important to note because the results indicate that Reading First and nonReading First principals scored the same in the area of Principal Assurance of School Climate Conducive to Literacy Development. 
Table 34

Principal Assurance of School Climate Conductive to Literacy Development (Items 21-30)

\begin{tabular}{|l|l|l|l|l|l|l|}
\hline Group & $\mathrm{N}$ & Mean & Difference & $\begin{array}{l}\text { Standard } \\
\text { Deviation }\end{array}$ & $t$ & $\begin{array}{l}\text { Significance } \\
*\end{array}$ \\
\hline $\begin{array}{l}\text { Reading } \\
\text { First }\end{array}$ & 28 & 3.60 & 0.00 & .282 & -.088 & .930 \\
\hline $\begin{array}{l}\text { non- } \\
\text { Reading } \\
\text { First }\end{array}$ & 28 & 3.60 & & .336 & & \\
\hline
\end{tabular}

As indicated by Table 34, the data revealed this did not yield a statistically significant difference. The 28 Reading First principals did not have a higher overall mean rating than the non-Reading First principals, $t=-.088, \mathrm{p}=.930$.

Additionally, it is interesting to note that Reading First and non-Reading First, demonstrated an equal mean in regard to the ten items in the category of Principal Assurance of School Climate Conductive to Literacy Development. This relationship is illustrated in Table 35. 
Table 35

Principal Assurance of School Climate Conductive to Literacy Development Low/High Response (Items 18-27)

\begin{tabular}{|l|l|l|}
\hline Question & Reading First & non-Reading First \\
\hline 18 & Tied & Tied \\
\hline 19 & Higher & Lower \\
\hline 20 & Lower & Higher \\
\hline 21 & Higher & Lower \\
\hline 22 & Higher & Lower \\
\hline 23 & Lower & Higher \\
\hline 24 & Higher & Lower \\
\hline 25 & Tied & Tied \\
\hline 26 & Higher & Lower \\
\hline $27 \quad T$ & Lower & Higher \\
\hline
\end{tabular}

$\mathrm{T}=$ Trend

As indicated in Table 35 Reading First and non-Reading First, demonstrate a relatively equal mean in regard to the ten items in the category of Principal Assurance of School Climate Conductive to Literacy. This is important to note because the results indicate that Reading First and non-Reading First principals had similar scores in the area of Principal Assurance of School Climate Conductive to Literacy. Reading First principals scored higher on 5 items, non-Reading First scored higher on 3 items, and tied on 2 items. 


\section{Research Question 2}

Research Question 2: Does the reading-instructional professional development of principals differ in Reading First Schools versus non-Reading First Schools?

This research question was tested through responses to 12 items. There are 12 items in this section. A Chi-Square compares the effects of the two variables (Reading First versus nonReading First) and will establish whether the variables differ significantly. A Chi-Square was computed for each of the items to determine if the Reading First principals $(n=28)$ rated the items different from the non-Reading First principals $(n=28)$.

Table 36 reveals data that the principal indicated for \#ndergraduate courses in reading." A Chi Square was computed.

Table 36

Question 28: Undergraduate courses in reading

\begin{tabular}{|l|l|l|}
\hline Response & Reading First & non-Reading First \\
\hline Yes & 19 & 21 \\
\hline No & 9 & 7 \\
\hline
\end{tabular}

$\chi^{2}=.350$

$p=.768$

As indicated by Table 36, the data in Item 28, «ndergraduate courses in reading," did not yield a significant finding.

Table 37 reveals data that the principal indicated for if yes, did they help." A Chi Square was not computed. 
Table 37

Question 29: If yes, did they help (see note)

\begin{tabular}{|l|l|l|}
\hline Response & Reading First & non-Reading First \\
\hline Yes & 14 & 17 \\
\hline No & 5 & 5 \\
\hline
\end{tabular}

Note: the results for the $\chi^{2}$ and $\mathrm{p}$ were not applicable and therefore not calculated.

As indicated by Table 37, the data for the $\chi^{2}$ and $p$ were not applicable and therefore not calculated.

Table 38 reveals data that the principal indicated for graduate courses in reading you took, if any." A Chi Square was computed.

Table 38

Question 30: Graduate courses in reading you took, if any

\begin{tabular}{|l|l|l|}
\hline Response & Reading First & non-Reading First \\
\hline Yes & 15 & 18 \\
\hline No & 12 & 9 \\
\hline
\end{tabular}

$\chi^{2}=.701$

$p=.785$

As indicated by Table 38, the data in Item 30, graduate courses in reading you took, if any" did not yield a significant finding.

Table 39 reveals data that the principal indicated for if yes, did they help." A Chi Square was not computed. 
Table 39

Question 31: If yes, did they help (see note)

\begin{tabular}{|l|l|l|}
\hline Response & Reading First & non-Reading First \\
\hline Yes & 13 & 17 \\
\hline No & 4 & 3 \\
\hline
\end{tabular}

Note: the results for the $\chi^{2}$ and $\mathrm{p}$ were not applicable and therefore not calculated. As indicated by Table 39 , the data for the $\chi^{2}$ and $\mathrm{p}$ were not applicable and therefore not calculated.

Table 40 reveals data that the principal indicated for professional reading of journal/articles pertaining to reading research and instruction.” A Chi Square was computed. Table 40

Question 32: Professional reading of journal/articles pertaining to reading research and instruction

\begin{tabular}{|l|l|l|}
\hline \multicolumn{1}{|c|}{ Response } & Reading First & non-Reading First \\
\hline Yes & 26 & 27 \\
\hline No & 2 & 1 \\
\hline
\end{tabular}

$\chi^{2}=.352$

$p=1.000$

As indicated by Table 40, the data in Item 32, — pofessional reading of journal/articles pertaining to reading research and instruction," did not yield a significant finding.

Table 41 reveals data that the principal indicated for professional development for Reading First schools at the school level.” A Chi Square was computed. 
Table 41

Question 33: Professional development for Reading First schools at the school level

\begin{tabular}{|l|l|l|}
\hline Response & Reading First & non-Reading First \\
\hline Yes & 23 & 4 \\
\hline No & 4 & 23 \\
\hline
\end{tabular}

$\chi^{2}=26.741$

$p=.000 *$ (significant)

As indicated by Table 41, the data in Item 33, professional development for Reading First schools at the school level," yielded a statistically significant difference in which the Reading

First principals rated this item higher than the non-Reading First Principals $\chi^{2}=26.741 p=.000$.

Table 42 reveals data that the principal indicated for training from WVDE pertaining to Reading First." A Chi Square was computed.

Table 42

Question 34: Training from WVDE pertaining to Reading First

\begin{tabular}{|l|l|l|}
\hline Response & Reading First & non-Reading First \\
\hline Yes & 23 & 15 \\
\hline No & 4 & 13 \\
\hline
\end{tabular}

$\chi^{2}=7.45$

$p=.019 *$ (significant)

As indicated by Table 42, the data in Item 34, training from WVDE pertaining to Reading First," yielded statistically significant differences in which the Reading First principals rated this item higher than non-Reading First Principals $\chi^{2}=7.45 p=.019$.

Table 43 reveals data that the principal indicated for -RESA level training in the area of reading." A Chi Square was computed. 
Table 43

Question 35: RESA level training in the area of reading

\begin{tabular}{|l|l|l|}
\hline Response & Reading First & non-Reading First \\
\hline Yes & 15 & 17 \\
\hline No & 11 & 10 \\
\hline
\end{tabular}

$\chi^{2}=.51$

$p=.834$

As indicated by Table 43, the data Item 35, RESA level training in the area of reading," did not yield a significant finding.

Table 4 reveals data that the principal indicated for reading content presented during

Principal Academy." A Chi Square was computed.

Table 44

Question 36: Reading content presented during Principal Academy

\begin{tabular}{|l|l|l|}
\hline Response & Reading First & non-Reading First \\
\hline Yes & 22 & 20 \\
\hline No & 6 & 7 \\
\hline
\end{tabular}

$\chi^{2}=1.17$

$p=.758$

As indicated by Table 44, the data in Item 36, reading content presented during Principal

Academy," did not yield a significant finding.

Table 45 reveals data that the principal indicated for experiences during teaching." A

Chi Square was computed. 
Table 45

Question 37: Experiences during teaching

\begin{tabular}{|l|l|l|}
\hline Response & Reading First & non-Reading First \\
\hline Yes & 23 & 27 \\
\hline No & 5 & 1 \\
\hline
\end{tabular}

$\chi^{2}=2.987$

$p=.193$

As indicated by Table 45, the data in Item 37, -experiences during teaching," did not yield a significant finding.

Table 46 reveals data that the principal indicated for -xperiences during principalship."

A Chi Square was computed.

Table 46

Question 38: Experiences during principal ship

\begin{tabular}{|l|l|l|}
\hline Response & Reading First & non-Reading First \\
\hline Yes & 27 & 28 \\
\hline No & 1 & 0 \\
\hline
\end{tabular}

$\chi^{2}=1018$

$p=1.000$

As indicated by Table 46, the data in Item 38, -xperiences during principal ship," did not yield a significant finding.

Table 47 reveals data that the principal indicated for interactions with teachers/reading specialists.” A Chi Square was computed. 
Table 47

Question 39: Interactions with teachers/reading specialists

\begin{tabular}{|l|l|l|}
\hline Response & Reading First & non-Reading First \\
\hline Yes & 27 & 26 \\
\hline No & 1 & 2 \\
\hline
\end{tabular}

$\chi^{2}=.352$

$p=1.000$

As indicated in Table 47, the data in Item 39, interactions with teachers/reading specialists," did not yield a significant finding.

Based on the data presented Table 48, an overall chi-square analysis across the 12 items of Principal Professional Development was computed. As with the individual item analyses, the independent variable was Reading First versus non-Reading First. In this analysis, however, the dependent variable was the total frequencies of the 12 questions (ratings) by the principals.

Table 48

Frequency of Responses of Principal Professional Development (Items 28-39)

\begin{tabular}{|l|l|l|l|}
\hline Response & Reading First & non-Reading First & Total \\
\hline Yes & 247 & 237 & 484 \\
\hline No & 64 & 81 & 145 \\
\hline Total Responses & 311 & 218 & 629 \\
\hline $\begin{array}{l}\chi^{2}=22.28 \\
p=.001\end{array}$ & & \\
\end{tabular}

As indicated by Table 48, the data revealed this chi-square analysis demonstrated a statistically significant difference between the 28 Reading First principals and the 28 non-Reading First principals. The chi-square value was 22.28 and was highly significant at the $\mathrm{p}<.001$ level. 
This finding indicates that the Reading First principals responded -yes" to the items 28 through 39 in a higher ratio (of yes to no) than did the non-Reading First principals (moreso than the nonReading First principals). It also is reported that the various experiences of professional development assisted leaders in acquisition of the skills and information needed in their development as reading instructional leaders. Table 48 presents the frequencies of responses of Principals Professional Development, Item 28-39.

\section{Research Question 3}

Research Question 3: Is there a difference in Reading/Language Arts WESTEST scores for the years 2005, 2006, and 2007 for the third grade students in Reading First versus non-Reading First Schools?

This research question was tested for (a) All Students (ALL), (b) Students Economically Disadvantaged subgroup (low SES), and (c) Students with Disabilities subgroup (SPED).

In West Virginia, schools are not compared against each other; but each is compared against a standard which is determined by a formula found in the NCLB legislation. All students are counted multiple times in the accountability system; once in the all students" group, once in a subgroup. Students are counted in every group in which $\mathrm{s} / \mathrm{he}$ is a member. This research looked at the ALL, and subgroups low SES and SPED to see if the achievement gap had closed between those groups with Reading First schools and non-Reading first schools. Statistics employed in analyzing these three parts of Research Question 3 included Mean $(M)$, Standard Deviation $(S D)$, Analysis of Variance (ANOVA, $F$ ), and $t$-Test $(t)$. Ultimately, the test addresses the cumulative impact of the program on student achievement, both between groups (Reading First versus non-Reading First schools) and within groups (WESTEST Reading/Language Arts for ALL Students in 2005, 2006, and 2007). In order to complete the 
research question data was needed for 3 years. The years needed are 2005, 2006, and 2007. Out of the 28 Reading First schools that responded to participate in the survey, only 24 had data needed. A school closed and the three other schools had consolidations. When consolidation happened the new schools had only 1 or 2 years of data.

Research Question 3, Part 1: ALL Students.

In order to complete the research question data were needed for 3 years. Out of the 28 Reading First schools that responded to participate in the survey, only 24 had the data needed. Table 49 reveals data that the (Reading First versus non-Reading First schools) mean scale scores and standard deviations for the outcomes are shown.

Table 49

Reading/Language Arts ALL

Descriptive Statistics - Mean Scale Scores and Standard Deviations

\begin{tabular}{|l|l|l|l|l|}
\hline & Group & $\begin{array}{l}\text { N } \\
\text { (Schools) }\end{array}$ & $\begin{array}{l}\text { Mean } \\
\text { Scale } \\
\text { Scores }\end{array}$ & $\begin{array}{l}\text { Standard } \\
\text { Deviation }\end{array}$ \\
\hline $\begin{array}{l}\text { ALL } \\
\text { Reading/Language } \\
\text { Arts 2005 }\end{array}$ & $\begin{array}{l}\text { Reading First } \\
\text { non-Reading } \\
\text { First }\end{array}$ & 24 & 627.62 & 5.41 \\
\hline $\begin{array}{l}\text { ALL } \\
\text { Reading/Language } \\
\text { Arts 2006 }\end{array}$ & $\begin{array}{l}\text { Reading First } \\
\text { non-Reading }\end{array}$ & 24 & 630.89 & 12.69 \\
\hline $\begin{array}{l}\text { ALL } \\
\text { First }\end{array}$ & 24 & 628.36 & 7.62 \\
Arts 2007 & $\begin{array}{l}\text { Reading First } \\
\text { non-Reading } \\
\text { First }\end{array}$ & 24 & 635.82 & 10.72 \\
\hline
\end{tabular}

As indicated by Table 49, the data revealed that the mean is higher in non- Reading First schools than Reading First schools.

In order to determine the impact on student achievement in both Reading First and nonReading First Scores, the mean scale scores and standard deviations were calculated. As may be 
noted there are six means and standard deviations for Reading First 2005, non-Reading First 2005, Reading First 2006, non-Reading First 2006, Reading First 2007, and non-Reading First 2007. These six means are illustrated in Figure 1. Figure 1 presents a graphic representation of the WESTEST Reading/Language Arts in all student mean scale scores Reading first and nonReading First Schools 2005 to 2007.

Figure 1 WESTEST Reading/Language Arts in ALL Students Mean Scale Scores Reading First and non-Reading First Schools 2005 to 2007

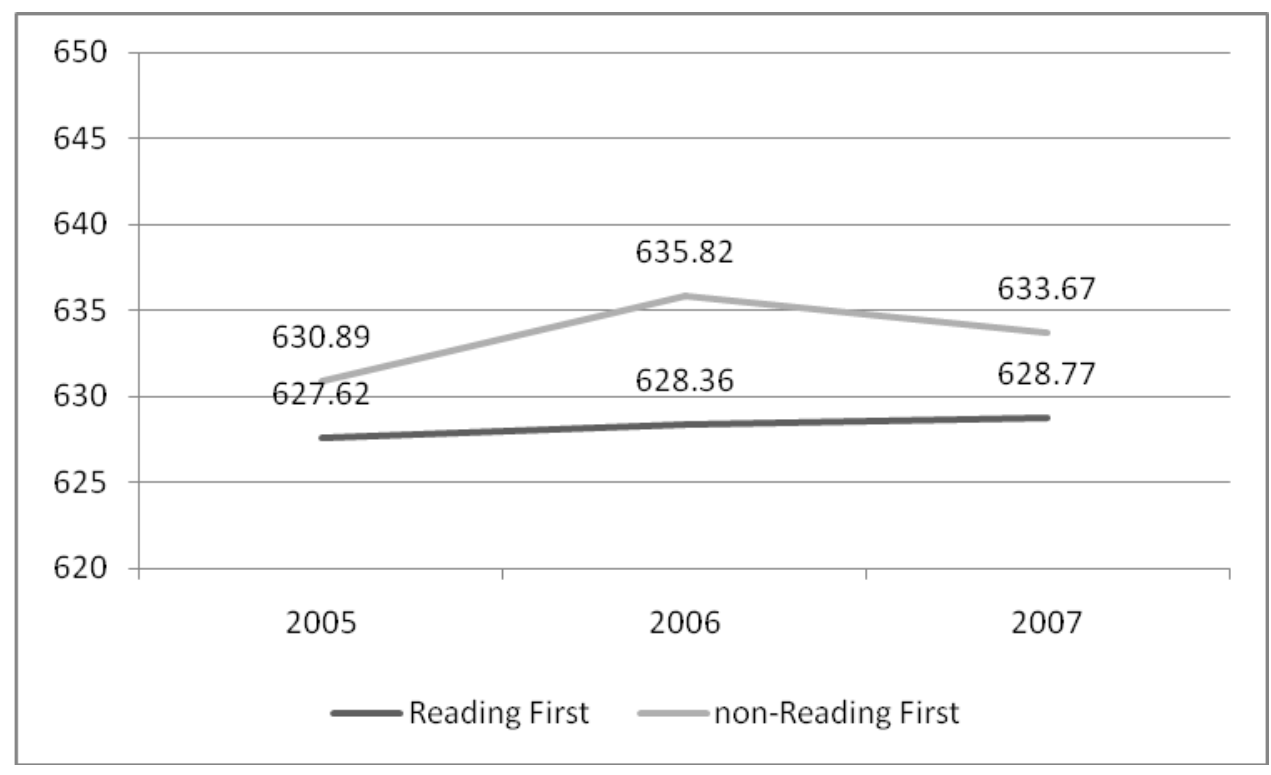

As can be noted in Figure 4 the three points (means) for the Reading First group lie below the three means for the non-Reading First group.

A key to understanding analysis of variance, or ANOVA, is to understand basic hypothesis and significance testing, in which a researcher tests the means of two or more groups to determine if the difference between them is statistically significant. ANOVA simply extends that procedure by comparing the means of more than two groups on an outcome or variable of interest (Walls, Personal Communication, Fall 2010). An overall ANOVA (Table 50) indicated that this between groups effect was statistically significant, 
$F(1,46)=5.57, p<.05$ (significant). Thus, taken together, the non-Reading First groups yields higher WESTEST Reading/Language Arts scores than did the Reading First group. Table 50

Reading/Language Arts ALL Students Test of Between-Subject Effects

\begin{tabular}{|l|r|l|l|l|l|}
\hline Source & $\begin{array}{c}\text { Sum of } \\
\text { Squares }\end{array}$ & $d f$ & Mean Square & $F$ & $p$ \\
\hline $\begin{array}{l}\text { Reading First } \\
\&\end{array}$ & & & & & \\
non-Reading & & & & & \\
$\begin{array}{l}\text { First } \\
\text { Error }\end{array}$ & 8076.709 & 1 & 976.709 & 5.566 & $.023^{*}$ \\
\hline
\end{tabular}

$\alpha=.05$

Thus, taken together, the non-Reading First group yields higher WESTEST

Reading/Language Arts scores than did the Reading First group. The non-Reading First schools scored significantly higher than the Reading First schools using WESTEST mean scale scores for Reading/Language Arts. Possible reasons for this statistically significant finding in the nonReading First school may include the random selection without control variables. This research study did not consider the percentage of low SES, special education students or total student population in the selection of the non-Reading First schools. The limitation of using random selection without control variables maybe due to the number of schools in the non-Reading First group.

Comparisons of the six individual means presented in Table 49 and Figure 1 were used to develop multiple comparisons which are summarized in Table 51. 
Table 51

Reading/Language Arts, ALL Students Multiple Comparisons among the Six Means

\begin{tabular}{|c|c|c|c|c|}
\hline Data 1 & s. Data 2 & $D f$ & $t$ & $p$ \\
\hline non-RF2005 & non-RF2006 & $1 / 23$ & 2.047 & $.05 \mathrm{SIG}$ \\
\hline nonRF2 005 & non-RF2007 & $1 / 23$ & 1.118 & $.28 \mathrm{NOT}$ \\
\hline non-RF2006 & non-RF2007 & $1 / 23$ & 0.817 & $.42 \mathrm{NOT}$ \\
\hline RF 2005 & RF 2006 & $1 / 23$ & 0.473 & $.64 \mathrm{NOT}$ \\
\hline RF 2005 & RF 2007 & $1 / 23$ & 0.941 & $.36 \mathrm{NOT}$ \\
\hline RF 2006 & RF 2007 & $1 / 23$ & 0.244 & $.81 \mathrm{NOT}$ \\
\hline non-RF2005 & RF 2005 & $1 / 23$ & 1.161 & $.25 \mathrm{NOT}$ \\
\hline non-RF2006 & RF 2006 & $1 / 23$ & 2.779 & $.01 \mathrm{SIG}$ \\
\hline non-RF2007 & RF 2007 & $1 / 23$ & 1.727 & .09 TREND \\
\hline
\end{tabular}

non-RF $=$ non-Reading First schools, $\mathrm{RF}=$ Reading First schools

The multiple comparisons in Table 51 indicate two statistically significant differences and one trend toward significance. The first difference indicates the non-Reading First 2005 data to be significantly lower than the non-Reading First 2006 data. The second difference shows the nonReading First 2006 data to be significantly higher than the Reading First 2006 data. The third finding is a trend $(p=.09)$ toward non-Reading First 2007 data being significantly higher than Reading First 2007 data.

Thus, the WESTEST Reading/Language Arts performance scores for ALL Students indicated somewhat higher performance for the non-Reading First schools. 


\section{Research Question 3, Part 2: Students Economically Disadvantaged (low SES)}

\section{Subgroup.}

Table 51 reveals data that the (Reading First, Experimental schools versus non-Reading First schools, Control schools) mean scale scores and standard deviations for the outcomes are shown.

Table 52

Reading/Language Arts low SES Subgroup Descriptive Statistics of Mean Scale Scores and Standard Deviations

\begin{tabular}{|l|l|l|l|l|}
\hline & Group & $\begin{array}{l}\text { N } \\
\text { (Schools) }\end{array}$ & $\begin{array}{l}\text { Mean } \\
\text { Scale } \\
\text { Scores }\end{array}$ & $\begin{array}{l}\text { Standard } \\
\text { Deviation }\end{array}$ \\
\hline $\begin{array}{l}\text { Low SES } \\
\text { Reading/Language } \\
\text { Arts 2005 }\end{array}$ & $\begin{array}{l}\text { Reading First } \\
\text { non-Reading } \\
\text { First }\end{array}$ & 24 & 621.07 & 8.26 \\
\hline $\begin{array}{l}\text { Low SES } \\
\text { Reading/Language } \\
\text { Arts 2006 }\end{array}$ & $\begin{array}{l}\text { Reading First } \\
\text { non-Reading } \\
\text { First }\end{array}$ & 24 & 622.84 & 12.92 \\
\hline $\begin{array}{l}\text { Low SES } \\
\text { Reading/Language } \\
\text { Arts 2007 }\end{array}$ & $\begin{array}{l}\text { Reading First } \\
\text { non-Reading } \\
\text { First }\end{array}$ & 24 & 621.87 & 9.82 \\
\hline
\end{tabular}

As indicated by Table 52, the data revealed that the mean is somewhat higher in non- Reading First schools than Reading First schools.

In order to determine the impact on student achievement in both Reading First and nonReading First Scores, the mean scale scores and standard deviations were calculated. As may be noted, there are six means and standard deviations for Reading First 2005, non-Reading First 2005,Reading First 2006,non-Reading First 2006, Reading First 2007 and non-Reading First 2007. These six means are illustrated in Figure 2. Figure 2 presents a graphic representation of 
the comparison of WESTEST Reading/Language Arts low SES subgroup mean scores for Reading First and non-Reading First schools from 2005 to 2007.

Figure 2 WESTEST Reading/Language Arts low SES Subgroup Mean Scores for Reading First and non-Reading First schools from 2005 to 2007.

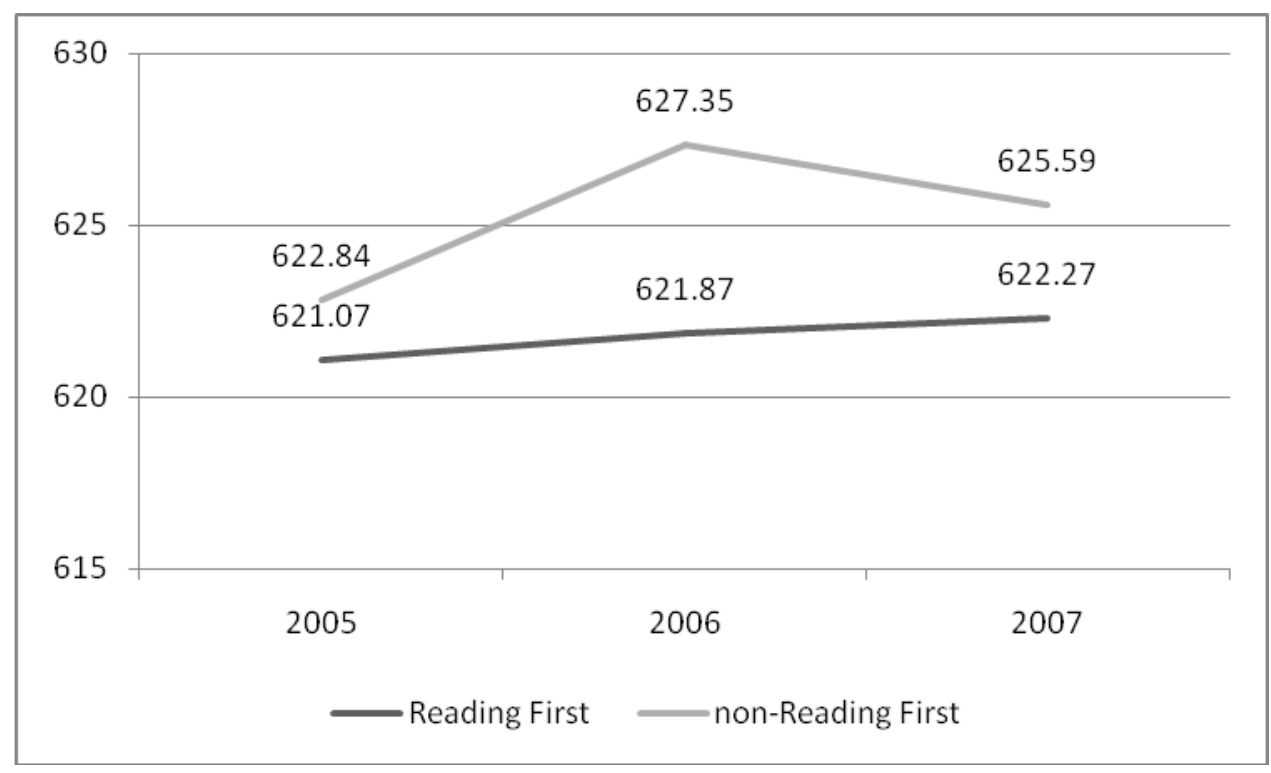

As can be noted in Figure 2, the three points (means) for the Reading First group lie below the three means for the non-Reading First group.

An overall ANOVA (Table 53) indicated that this between groups effect was not statistically significant, $F(1,46)=2.589, p=.44$. 
Table 53

Reading/Language Arts low SES Subgroup Test of Between-Subject Effects

\begin{tabular}{|c|c|c|c|c|c|}
\hline Source & $\begin{array}{l}\text { Sum of } \\
\text { Squares }\end{array}$ & $d f$ & $\begin{array}{l}\text { Mean } \\
\text { Square }\end{array}$ & $F$ & $p$ \\
\hline $\begin{array}{l}\text { Reading First \& } \\
\text { non-Reading } \\
\text { First } \\
\text { Error }\end{array}$ & $\begin{array}{l}447.577 \\
953.430\end{array}$ & $\begin{array}{l}1 \\
46\end{array}$ & $\begin{array}{l}447.577 \\
172.901\end{array}$ & 2.589 & .114 \\
\hline
\end{tabular}

The non-reading First schools scored significantly higher than the Reading First schools using WESTEST mean scale scores for Reading/Language Arts.

Comparisons of the six individual means presented in Table 52 and Figure 2 were used to develop multiple comparisons which are summarized in Table 54. 
Table 54

Reading/Language Arts, low SES subgroup Multiple Comparisons among the Six Means

\begin{tabular}{|l|l|l|l|l|}
\hline \multicolumn{2}{|c|}{ Data 1 } & \multicolumn{1}{|c|}{ Data 2 } & $t$ & $p$ \\
\hline non-RF 2005 & non-RF2006 & $1 / 23$ & 1.384 & .18 NOT \\
\hline non-RF 2005 & non-RF 2007 & $1 / 23$ & .834 & .41 NOT \\
\hline non-RF 2006 & non-RF 2007 & $1 / 23$ & .572 & .57 NOT \\
\hline RF 2005 & RF 2006 & $1 / 23$ & .364 & .72 NOT \\
\hline RF 2005 & RF 2007 & $1 / 23$ & .597 & .56 NOT \\
\hline RF 2006 & RF 2007 & $1 / 23$ & .167 & .87 NOT \\
\hline non-RF 2005 & RF 2005 & $1 / 23$ & .567 & .57 NOT \\
\hline non-RF 2006 & RF 2006 & $1 / 23$ & 1.768 & .08 TREND \\
\hline non-RF 2007 & RF 2007 & $1 / 23$ & 1.045 & .30 NOT \\
\hline
\end{tabular}

non-RF $=$ non-Reading First, $\mathrm{RF}=$ Reading First

The multiple comparisons in Table 54 indicate no statistically significant differences. There was one trend toward significance in which the non-Reading First 2006 had a trend toward higher scores than the Reading First 2006.

Thus, the WESTEST Reading/Language Arts performance scores for low SES Subgroup indicated no statistically significant differences across the years $(2005,2006$, and 2007) between the Reading First schools and non-Reading First schools. 


\section{Research Question 3, Part 3: Disabilities Subgroup (SPED).}

Table 55 reveals data that the Reading First schools versus non-Reading First schools mean scale scores and standard deviation for the outcomes are shown.

Table 55

Reading/Language Art Disabilities Subgroup (SPED) Descriptive Statistics

Mean Scale Scores and Standard Deviations

\begin{tabular}{|l|l|l|l|l|}
\hline & Group & $\begin{array}{l}\text { N } \\
\text { (Schools) }\end{array}$ & $\begin{array}{l}\text { Mean } \\
\text { Scale } \\
\text { Scores }\end{array}$ & Standard Deviation \\
\hline $\begin{array}{l}\text { Disabilities } \\
\text { Subgroup } \\
\text { Reading/Language } \\
\text { Arts 2005 }\end{array}$ & $\begin{array}{l}\text { Reading } \\
\text { First } \\
\text { non- } \\
\text { Reading } \\
\text { First }\end{array}$ & 24 & 592.90 & 20.20 \\
\hline $\begin{array}{l}\text { Disabilities } \\
\text { Subgroup } \\
\text { Reading/Language } \\
\text { Arts 2006 }\end{array}$ & $\begin{array}{l}\text { Reading } \\
\text { First } \\
\text { non- } \\
\text { Reading } \\
\text { First }\end{array}$ & 24 & 603.63 & 22.59 \\
\hline $\begin{array}{l}\text { Disabilities } \\
\text { Subgroup } \\
\text { Reading/Language } \\
\text { Arts 2007 }\end{array}$ & $\begin{array}{l}\text { Reading } \\
\text { First } \\
\text { non- } \\
\text { Reading } \\
\text { First }\end{array}$ & 24 & 698.59 & 24.81 \\
\hline
\end{tabular}

As indicated by Table 55, the data revealed that the mean is somewhat higher in non- Reading First schools than Reading First schools.

In order to determine the impact on student achievement in both Reading First and nonReading First Scores, the mean and standard deviations were calculated. As may be noted there are six means and standard deviations for Reading First 2005, non-Reading First 2005, Reading First 2006, non-Reading First 2006,Reading First 2007 and non-Reading First 2007. These six means are illustrated in Figure 3. Figure 3 presents a graphic representation of the comparison 
between WESTEST Reading/Language Arts SPED subgroup mean scales scores Reading First and non-Reading Schools from 2005 to 2007.

Figure 3 WESTEST Reading/Language Arts SPED Subgroup Mean Scales Scores

Reading First and non-Reading First Schools from 2005 to 2007.

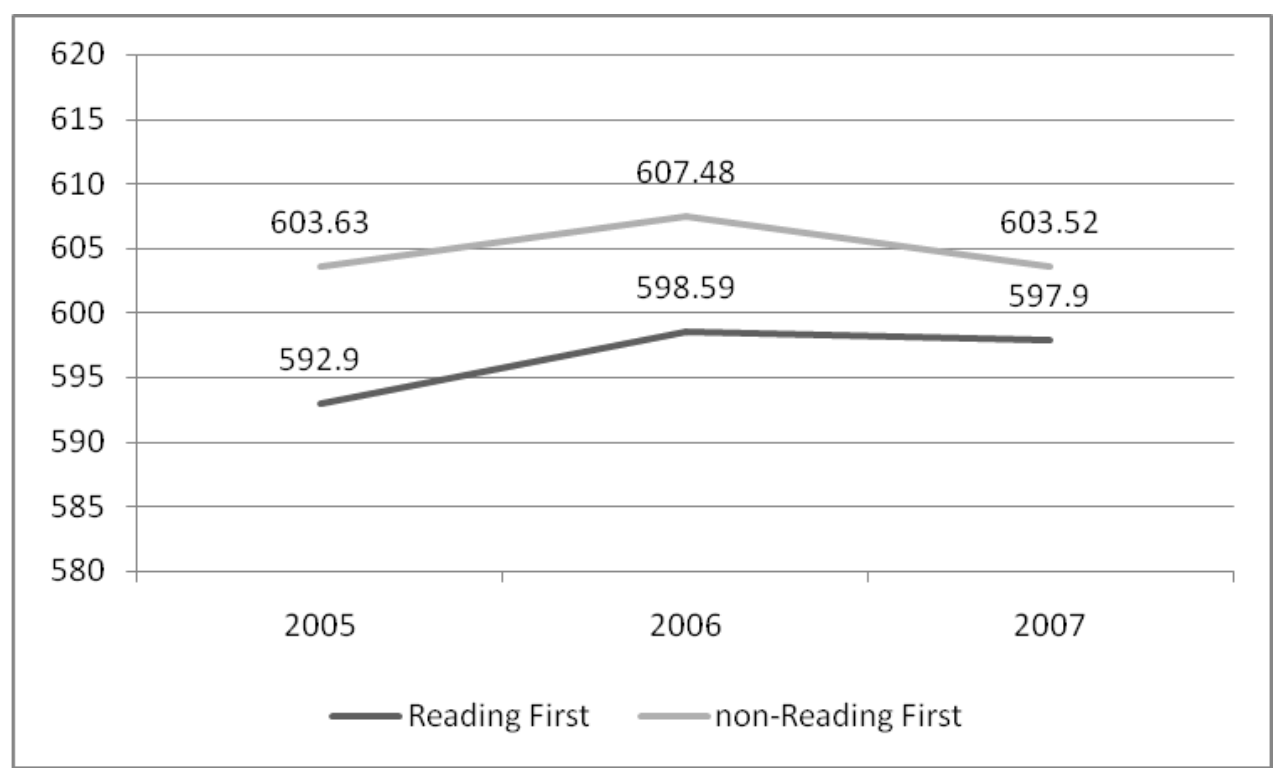

As can be noted in Figure 3, the three points (means) for the Reading First group lie below the three means for the non-Reading First group.

An overall ANOVA (Table 56) indicated that this between groups effect was a trend toward significance, $F(1,46)=3.239 p=.072$ (trend). Thus taken together, the non-Reading First group yields a trend toward higher WESTEST Reading/Language Arts scores than did the Reading First group. 
Table 56

Reading/Language Arts SPED Subgroup Test Between-Subject Effects

\begin{tabular}{|c|c|c|c|c|c|}
\hline Source & $\begin{array}{l}\text { Sum of } \\
\text { Squares }\end{array}$ & $d f$ & $\begin{array}{l}\text { Mean } \\
\text { Square }\end{array}$ & $F$ & $p$ \\
\hline $\begin{array}{l}\text { Reading First } \\
\& \\
\text { non-Reading } \\
\text { First } \\
\text { Error }\end{array}$ & $\begin{array}{l}2470.316 \\
3524.66\end{array}$ & $\begin{array}{l}1 \\
46\end{array}$ & $\begin{array}{r}2470.316 \\
728.906\end{array}$ & 3.389 & .072 \\
\hline
\end{tabular}

The non-reading First schools demonstrated a trend toward higher scores than the Reading First schools using WESTEST mean scale scores for Reading/Language Arts.

Comparisons of the six individual means presented in Table 55 and Figure 3 were used to develop multiple comparisons which are summarized in Table 57. 
Table 57

Reading/Language Arts, SPED subgroup Multiple Comparisons among the Six Means

\begin{tabular}{|l|l|l|l|l|}
\hline \multicolumn{2}{|c|}{ Data 1 } & \multicolumn{1}{|c|}{ Data 2 } & $d f$ & $T$ \\
\hline non-RF 2005 & non-RF 2006 & $1 / 23$ & .652 & .52 NOT \\
\hline non-RF 2005 & non-RF 2007 & $1 / 23$ & .092 & .93 NOT \\
\hline non-RF 2006 & non-RF 2007 & $1 / 23$ & .717 & .48 NOT \\
\hline RF2005 & RF 2006 & $1 / 23$ & .889 & .38 NOT \\
\hline RF 2005 & RF 2007 & $1 / 23$ & .831 & .42 NOT \\
\hline RF 2006 & RF 2007 & $1 / 23$ & .103 & .92 NOT \\
\hline non-RF 2005 & RF 2005 & $1 / 23$ & 1.735 & .09 TREND \\
\hline non-RF 2006 & RF 2006 & $1 / 23$ & 1.272 & .21 NOT \\
\hline non-RF 2007 & RF 2007 & $1 / 23$ & .758 & .45 NOT \\
\hline
\end{tabular}

non-RF $=$ non-Reading First, $\mathrm{RF}=$ Reading First

The multiple comparisons in Table 57 indicate no statistically significant differences. There was one trend toward significance in which the non-Reading First 2005 had a trend toward higher scores than the Reading First 2005.

Thus, the WESTEST Reading/Language Arts performance scores for SPED Subgroup indicated no statistically significant differences across the years $(2005,2006$, and 2007) between the Reading First schools and non-Reading First school. As noted previously, this may have occurred because of the random selection without control variables. The limitation of using random selection without control variables is due to the number of schools in the non-Reading First group. 


\section{Summary}

The purpose of the study was to examine the reading instructional leadership practices and professional development of elementary principals in West Virginia. Populations of 343 K-5 public elementary school principals in West Virginia were invited to participate in this survey research study. There were 40 Reading First West Virginia K-5 public elementary principals, leaving 303 from which to select 40 non-Reading First West Virginia K-5 public elementary principals which yielded a $70 \%$ response rate. This study further examined the percentage of students who scored mastery or above as measured by the third grade Reading/Language Arts West Virginia Educational Standards Test (WESTEST) in the years 2005, 2006, and 2007.

Data for the study were collected electronically through the utilization of Survey Monkey to both distribute and collect survey responses from the participants. The Survey of Selected K-5 Public Elementary Principals in West Virginia: Reading Instructional Leadership served as the survey instrument. The overall research compared differences between Reading First and nonReading First, principals‘ professional development, reading instructional leadership practices and the students' Reading/Language Art test scores as measured by the WESTEST during 2005, 2006, and 2007 from both groups (Reading First and non-Reading First).

This study investigated the possibility of statistically significant differences between the variables in the reading First schools compared to the non-Reading First Schools. These variables include student WESTEST scores and reading instructional leadership practices of the principals. The study also examines the frequencies and means of the principals' demographic data: gender, years spent teaching reading, number of reading courses taken, years as principal in what grade level, and hours spent on instructional issues. 
The three research questions were:

1) Do the reading-instructional-leadership practices of principals differ in Reading First Schools versus non-Reading First Schools?

2) Does the reading-instructional-leadership professional development of principals differ in Reading First Schools versus non-Reading First Schools?

3) Is there a difference in Reading/Language Arts WESTEST scores for the years 2005, 2006 and 2007 for third grade students in Reading First versus Non-Reading First Schools?

In addition to the three research questions, data were collected from participants regarding demographics and to specifically address the three research questions. Research Question 1 was tested through responses to 27 items in three sections. There were six items in the first section, Principal as Resource Provider. There were eleven items in the second section, Principal Interaction with Teachers. There were ten items in the third section, Principal Assurance of School Climate Conductive to Literacy Development. A $t$-test was computed for each of the items to determine if the Reading First principals $(n=28)$ rated the items different from the non-Reading First principals $(\mathrm{n}=28)$.

Research Question 1 was divided into three sections in the survey; Principal as a Resource Provider, Principal Interaction with Teachers, and Principal Assurance of School Climate. Data collected to address Research Question 1, Section 1, indicates that Reading First Principals had a higher mean for each of the six items in the category of Principal as Resource Provider than the non-Reading First Principals. Section 2, which examines the principal's interaction with teachers, indicated that each of the two types of principals, Reading First and non-Reading First, demonstrate an equal mean in regard to the ten items in the category 
of Principal Interaction with Teachers. Results from section 3 suggest that Reading First Principals had a somewhat higher mean for five of the ten items, Reading First principals and non-Reading First principals on two of the items tied, and Reading First principals were lower in three of the items in the category of Principal Assurance of School Climate Conductive to Literacy.

Research Question 2 which considers the reading-instructional professional development of principals demonstrated a statically significant difference between the 28 Reading First principals and the 28 non-Reading First principals through a summary of the chi-square analysis results. In addition, the research indicated the impact of various experiences of professional development which helped them acquire the skills and information they needed as the reading instructional leaders in their schools.

Research Question 3 data collected to address the statistical significant difference for Reading/Language Arts WESTEST scores both between and within groups. The research question was tested for 3 groups (ALL, low SES, SPED). Each of the three areas reveals a higher percentage of student achievement in non-Reading First schools. 


\section{CHAPTER V: SUMMARY, CONCLUSION, DISCUSSION, AND RECOMMENDATION}

This chapter will include a summary, study conclusion, discussion, and recommendations for practice and research.

\section{Summary}

This study was designed to compare the reading instructional leadership practices and professional development of Reading First principals with non-Reading First principals in West Virginia. There were 40 Reading First West Virginia K-5 public elementary principals, leaving 303 from which to select 40 non-Reading First West Virginia K-5 public elementary principals by a random sample. The final survey sample included 28 Reading First principals and 28 nonReading First principals. The study also compared the percentage of students who have scored mastery or above as measured by the third grade Reading/Language Arts West Virginia Educational Standards Test (WESTEST) in the years 2005, 2006, and 2007. The overall research compared differences between Reading First and non-Reading First principals‘ (1) reading instructional leadership practices, (2) professional development practices, and (3) the students' Reading/Language Arts test scores by the WESTEST during 2005, 2006, and 2007 from both groups (Reading First and non-Reading First).

The data were collected through the utilization of a survey instrument, the Survey of Public Elementary Principals in West Virginia: Reading Instructional Leadership developed specifically for this study. The survey instrument is adapted from the work of Dr. Mary Porter (2001). Principals in Porter's study were found to believe that experience, both as a teacher and principal, provided them with the most information and skills that they need as reading instructional leaders. Porter's research also indicated the need to identify effective behaviors of reading instructional leadership at the secondary level that would impact student achievement. 
Porter's work is based on established correlations between the principals` instructional leadership behaviors and school outcomes, including student achievement (Bossert, Dwyer Rowan, \& Lee 1982; Hallinger \& Murphy, 1983; Pitner, 1988). Additional research (Boyan, 1988; Heck, Larsen, \& Marcoulides, 1990) has established a correlation between school effectiveness and student achievement which suggests that leadership directly impacts academic achievement. Brookover (1987) identified principal leadership as a correlate of effective schools, and cautioned that leadership alone is not sufficient to produce high achievement. The survey responses from 28 Reading First and 28 randomly selected non-Reading First principals provide the basis for several conclusions.

\section{Research Questions}

Research Question 1: Do the reading-instructional-leadership practices of principals differ in Reading First Schools versus non-Reading First Schools?

No, the reading instructional-practices of principals in Reading First and non-Reading First schools differ in only one dimension, Principal as a Resource Provider. However, no other reading instructional practice showed a statistically significant difference. Porter (2001) also discovered a similar finding. Porter found that principals perceive their primary leadership role as one of resource provider and focus energy toward providing standardized test data, discussion of that data, and overseeing activities that are directly aimed at improving standardized test scores. Porter asserted that principals focus their efforts in familiar areas in which they have experience and training.

Research question one was tested through responses to 26 items in three sections: Principal as Resource Provider, Principal Interaction with Teachers, and Principal Assurance of School Climate Conductive to Literacy Development. It was confirmed that there was a difference in regard 
to reading-instructional-practices of principals in Reading First Schools versus non-Reading First Schools, but in only one dimension: the Principal as a Resource Provider.

The data revealed the following pertaining to reading-instructional leadership practices of principals in Reading First and non-Reading First schools: a statistically significant difference in overall analysis of data. The results indicate that Reading First principals scored higher in the area of Principal as Resource Provider. The 28 Reading First principals had a higher overall mean rating than the non-Reading First principals. Additionally, Reading First Principals had a higher mean for each of the six items in the category of Principal as Resource Provider questions, than the nonReading First Principals.

Based on the data and with no exceptions, Reading First participants in this study considered themselves as resource providers for their teachers. This held true in each of the six items on section one. Reading First Principals had a higher mean for each of the six items in the category of Principal as Resource Provider questions than the non-Reading First Principals.

The survey instrument assessed activities (1) providing funding to build classroom libraries, (2) providing resources for Tier II and III interventions, (3) facilitating professional development for teachers, (4) providing opportunities for teachers to attend conferences, (5) providing follow up trainings, and (6) facilitates data analysis. The results indicate a statistically significant finding between the Reading First principals and non-Reading First their perception of themselves as resource providers.

The second section of Research Question 1 includes the area of Principal Interaction with Teachers. Although, the results indicate no statistically significant difference, the 28 Reading First principals did have a higher overall mean rating than the non-Reading First principals. Specifically, the results would indicate that Reading First principals may check lesson plans more frequently, 
participate in interviewing and hiring new teachers, listen to children read, and read to students more often.

Although the results indicate no statistically significant difference, the non-Reading First principals scored somewhat higher means in the areas of sharing information with faculty to keep them aware of what is happening in the school, participating in data analysis, walkthroughs to assure reading fidelity, and providing opportunities for celebrations.

The third section of research question one includes the area of Principal Assurance of School Climate Conducive to Literacy Development. The overall analysis across the ten items of Principal Assurance of School Climate Conducive to Literacy Development was computed and results indicate that Reading First and non-Reading First principals scored the same in the area of Principal Assurance of School Climate Conducive to Literacy Development.

Although no statistically significant differences were found, it can be noted that the Reading First principals had somewhat higher means in the areas of supporting special activities that focus on instructional goals tested on WESTEST, TIER II and III for students, tutoring programs, displaying student work, and reading to students by guests and parents.

Although no statistically significant differences were found, it can be noted that non-Reading First principals had somewhat higher means in the areas of supporting reading and literature courses for students in all grades, interaction among faculty, and assurance of school and classroom incentive programs for reading.

Research Question 2: Does the reading-instructional-leadership professional development of principals differ in Reading First Schools versus non-Reading First Schools?

Yes, the reading-instructional- leadership professional development of principals differs in Reading First and non-Reading First Schools. The findings indicate a statistically significant 
difference in that the Reading First principals were more likely to response yes" than were their non-Reading First principals to the items regarding the various experiences of professional development that assisted leaders in acquiring skills and information needed in their development as reading instructional leaders.

This research question was tested through responses to 12 items in Professional Development. This section of the survey considers the reading-instructional professional development of principals and demonstrated a statically significant difference between the 28 Reading First principals and the 28 non-Reading First principals through a summary of the chi-square analysis results. In addition, the research indicates the impact of various experiences of professional development which assisted leaders in the acquisition of the skills and information needed in their development as reading instructional leaders.

The data reveal that for items 33 and 34 in Section 4, which consider professional development at the school level for Reading First and non-Reading First schools, the results yielded a statistically significant difference in which the Reading First principals rated this item higher than the non-Reading First Principals. Data also indicate that the various experiences of professional development assisted leaders in acquisition of the skills and information needed in their development as reading instructional leaders.

Some activities, however, were less known to be performed by Reading First principals than others as indicated by a lower percentage of overall yes" responses. Given the results of the study, it is evident Reading First K-5 principals participating in this study are cognizant of the impact of these particular reading professional development activities within their schools and are utilizing their time to assure that professional development at the school level is occurring in order for improving reading instruction. 
The overall analysis across the eleven items of Principal Professional Development was computed using chi-square, and results indicate that Reading First Principals responded yes" at a higher ratio than the non-Reading First Principals. The Reading First principals` response would indicate that they perceive the various experiences of professional development as assisting them in acquiring the skills and information needed in their development as reading instructional leaders.

Research Question 3: Is there a difference in Reading/Language Arts WESTEST scores for the years 2005, 2006, and 2007 for the third grade students in Reading First versus non-Reading First Schools?

Yes, there is a difference in Reading/Language Arts WESTEST scores for the years 2005, 2006 and 2007 for third grade students in Reading First versus non-Reading First Schools. The nonReading First third grade students scored higher in Reading/Language Arts WESTEST in the ALL subgroup. In the subgroup of low SES the non-Reading First students scored significantly higher. Finally, in the subgroup of SPED, there was a trend toward higher scores for the non-Reading First Schools.

Analyses were used to examine patterns in the WESTEST scores in the areas of Reading/Language Arts Achievement. This research question was tested for (a) All Students, (b) Students Economically Disadvantaged subgroup (low SES), and (c) Students with Disabilities subgroup (SPED). Statistics were calculated to address the cumulative impact of the program on student achievement, both between groups and within groups.

The data reveal that third grade students in the ALL" subgroup, non-Reading First schools participating in this study scored higher than their third grade peers in the ALL" group in Reading First schools. The data also reveal that the non-Reading First Schools demonstrated a statistically significant difference and higher achievement scores than the Reading First 
schools using WESTEST mean scale scores for Reading/Language Arts in the ALL" group. The overall ANOVA results indicated that the between groups effect was statistically significant. Thus, taken together, the non-Reading First yields higher WESTEST Reading/Language Arts scores, than did the Reading First.

Additionally, the multiple comparisons indicate two statistically significant differences and one trend toward significance. The first difference indicates the non-Reading First (2005) data to be significantly lower than the non-Reading First (2006) data. The second difference shows the nonReading First (2006) data to be significantly higher than the Reading First (2006) data. The third finding is a trend toward non-Reading First (2007) data being significantly higher than Reading First (2007) data. Thus, the WESTEST Reading/Language Arts performance scores for All Students indicated somewhat higher performance for the non-Reading First schools.

The subgroup of low SES was also considered. When considering the subgroup of low SES there was a trend toward higher scores for the non-Reading First students compared to the Reading First third grade students. The means for the Reading First lie below the three means for the non-Reading First. The overall ANOVA indicated that this between groups effect was not statistically significant. The non-reading First schools scored higher than the Reading First schools using WESTEST mean scale scores for Reading/Language Arts.

Additionally, the multiple comparisons indicate no statistically significant differences. There was one trend toward significance in which the non-Reading First schools (2006) had a trend toward higher scores than the Reading First (2006). Thus, the WESTEST Reading/Language Arts performance scores for low SES subgroup indicated no statistically significant differences across the years $(2005,2006$, and 2007) between the Reading First and non-Reading First. 
The subgroup of SPED, was also considered. When considering the subgroup of special education there was a trend toward higher scores for the non-Reading First students compared to the Reading First third grade students. The means for the Reading First lie below the three means for the non-Reading First. An overall ANOVA indicated that this between groups effect was a trend toward significant. Thus taken together, the non-Reading First yields a trend toward higher WESTEST Reading/Language Arts scores than did the Reading First.

In summary, the non-reading First schools demonstrated a trend toward higher scores than the Reading First schools using WESTEST mean scale scores for Reading/Language Arts in the subgroup of special education. The multiple comparisons indicate no statistically significant differences. There was one trend toward significance in which the non-Reading First (2005) had a trend toward higher scores than the Reading First (2005). Thus, the WESTEST Reading/Language Arts performance scores for SPED subgroup indicated no statistically significant differences across the years $(2005,2006$, and 2007) between the Reading First and non-Reading First.

The findings of this study indicate that Reading First principals perceived themselves as a resource provider, establishing classroom libraries, and providing resources for TIER II and TIER III. Additionally, Reading First principals valued professional development at the school level that assisted in acquisition of the necessary skills and information for reading instructional leadership more often than did the non-Reading First principals. They are also more involved in the interviewing process and hiring of new teachers, and check lesson plans more frequently than did non-Reading First principals. Also, Reading First principals had higher means in the areas of supporting special activities that focus on instructional goals tested on WESTEST, tutoring programs, displaying student work, and reading to students by guests and parents. 
However, considering all of the findings, there was no statistically significant impact on student standardized test scores in Reading First schools.

\section{Conclusions}

Study results reveal that Reading First principals were better resource providers than non-Reading First principals. Additionally, Reading First principals supported reading professional development activities for teachers at the school level at a statistically significantly higher rate than did the non-Reading First principals. Finally, there was no statistically significant impact on student achievement as measured by standardized test scores in the Reading First Schools versus non-Reading First schools.

\section{Discussion}

Reading First, a primary part of the 2002 No Child Left Behind law received \$1 billion dollars a year nationally; however, national research completed by the USDE (2008) concur with this research study results and indicate that children in schools receiving Reading First funding had virtually no better reading achievement scores on standardized tests than those in schools that did not receive the funding.

West Virginia received approximately $\$ 43.8$ million over a period of six years to administer the Reading First program beginning in 2004. Reading First was implemented in the selected counties with the goal of designing reading instruction based on scientific research. The West Virginia counties include: Calhoun, Doddridge, Fayette, Gilmer, Hampshire, Hardy, Kanawha, Lincoln, Logan, Mason, McDowell, Mercer, Mineral, Mingo, Monongalia, Nicholas, Pocahontas, Preston, Roane, Summers, Tucker, Upshur, Webster, Wetzel and Wirt. These counties received close to one million dollars per school that would allow low performing schools to implement the program. However, this research indicated that despite all of the 
invested monies and time, Reading First students' reading scores on standardized tests were nearly indistinguishable from those of students in non-Reading First schools.

A primary focus of the Reading First program included intense professional development for teachers and administrators. Professional development requirements resulted in the 28 participating Reading First principals taking part in 16,800 hours of training over the period of six years. Teacher professional development in Reading First Schools placed emphasis on phonics, scripted instruction by teachers and detailed data analyses of children's skills. There were 100 hours of mandatory Reading First professional development per year for each classroom teacher, which was monitored at the state and county level. These schools had the financial means, and support from central office to offer the resources and professional development. Additionally, it is important to consider the West Virginia Department of Education and Federal accountability measures in place to support and monitor Reading First principals and schools. However, according to the research, there was no resulting impact in raised reading achievement scores. This result was also found among the targeted low-income and special education student populations.

In this research study, student achievement was considered. The data reveal that nonReading First students scored significantly higher than their peers in Reading First schools. Possible reasons for this statistically significant finding in the non-Reading First schools may include the random selection for this research without control variables. This research study did not consider the percentage of low SES, special education students, or total student population in the selection of the non-Reading First schools. The limitation of using random selection without control variables is due to the number of schools in the control group. Additionally, the Reading First grant was not funded until 2004; with the first student achievement data collected 
in 2005. This possibly did not provide the necessary time to fully implement the changes needed to impact student achievement. Sustainability must be considered when evaluating impact on student achievement.

The question of - Đid Reading First make a difference?" must be considered. While critics will likely say the data portray Reading First as an expensive failure, this research study suggests that schools may have impacted. As the researcher, a principal, curriculum director and current school superintendent, I believe Reading First had an impact on the school reading culture. Teachers and principals attended professional development, resulting in conversations regarding reading best practices, research and data. However, student achievement was not impacted as a result.

Is it considered positive that Reading First is no longer in existence? The answer involves a number of variables that are very broad. Although the research did not indicate that Reading First has had any systematically positive effects on the quality of instruction provided in Reading First schools, it does not conclude that everything is as it should be in these schools. To define success, one must consider the measurements of that success. Is it defined by individual student gains, student achievement on WESTEST, leadership growth, school culture improvement or effective management in the day-to-day operation of schools? Additionally, one must consider the inequalities of the educational system that are attributable to poverty and cultural differences. This research considered achievement; however, it did not consider gains of individual student achievement. Perhaps, if that was a consideration, many schools would have demonstrated success. Just as the master teacher will try a number of measures in order to determine what best meets the instructional needs of her student, education is an ongoing cycle of growth. During the Reading First experience, education experienced growth and lessons 
learned. The Reading First Schools were selected to receive grant monies based on low achievement and SES. Clearly we have learned a great deal in the last 20 years about how children learn to read, what makes learning to read difficult for many students, and how to teach students who struggle in learning to read. We have a responsibility to see that our new knowledge in these areas is applied for the benefit of all students. This research study indicates we must consider how to increase the quality of instruction provided to our poor and special education students in order to improve their school success. Ultimately, we continue the search for answers to improve student achievement in low performing schools.

\section{Recommendations for Practice}

This study involved a closer examination of the differences between Reading First and non-Reading First, principals' professional development, reading instructional leadership practices and student achievement. Based on the research of Reading First, effective principals are adept at prioritizing, informed about alignment issues, knowledgeable about assessments, and supportive of teacher professional development and collaboration. Highly effective reading instructional leaders will most likely open the door to school improvement and increased student achievement (Hillard \& Guglielmino, 2002).

There are many obstacles that principals must overcome in order to be effective reading instructional leaders in their schools. Classic obstacles include teacher resistance to change, and county wide directives that are not aligned with reading research. In West Virginia and other states, we find schools with comparable student populations and varying degrees of student achievement. Strong instructional leadership may be the key to managing the obstacles that may hinder the success of an effective reading program. This will continue to challenge school leaders in our state and across the nation. According to the research, principals who have depth 
of knowledge in reading are better prepared to have discussions with classroom teachers focused on instruction and student achievement (Edmonds, 1982). An important component of Reading First was to build strong instructional leadership in schools through professional development. The Reading First grant called for the role of principals to change and shift of emphasis from being managers to instructional leaders. Principals in the 21 st Century must learn to manage a number of roles, with instructional leadership at the forefront (Braughton \& Riley, 1991). This shift was influenced largely by research which found that effective schools usually had principals who stressed the importance of instructional leadership (Edmonds, 1980; Cuban, 1984; Hoyle, 1988; Lezotte, 2004; Fullan, 2007). Effective school leadership today must combine the traditional school leadership duties such as teacher evaluation, budgeting, scheduling, and facilities maintenance with high involvement with specific aspects of teaching and learning (Scheerens \& Boskers, 1997).

The instructional leaders must have a clear vision of effective reading instruction and scientifically-based reading research. In addition, the leadership must also be willing to constantly monitor the progress of reading programs and instruction to be certain that highquality instruction is occurring, and make informed data-based instructional decisions. At the county level, this leadership model may include monitoring principal effectiveness. At the state level, recommendations include building a foundation for strong reading leadership teams at the state, county, and school levels. This is a critical step toward achieving the overall goal of improved student outcomes in reading for all students, including students with special and diverse learning needs. As state superintendent, it is vital to assure all educational leaders have professional development in effective reading instructional practices. Additionally, this research has implications for many educational leadership groups. Principal professional development in 
reading instruction must occur at all levels, sustained throughout their career, and continually updated with current reading research best practices.

Reading is the foundation to assure academic success across the curriculum. It is not a subject; rather the means by which the entire world communicates. This skill must continue to be at the vanguard of the national, state and local educational agendas. Challenging state and local education agencies is the lack the resources and technical support needed in order to improve reading instructional leadership across the nation. Therefore, adequate funding to assure necessary supports must be in place at national, state and local levels.

In order to sustain strong instructional leadership, state, local, and federal initiatives must focus on principal professional development around a limited number of high-impact initiatives, and solid and dedicated leadership. The current national, state and local emphasis on accountability has reignited interest in instructional leadership. Strong principals have a clear understanding of teacher capacity and are able to direct teachers regarding effective instructional practices. Effective leaders provide direct assistance to teachers in their day-to-day activities, and make research based decisions (Glickman, Gordon, \& Ross-Gordon, 1995).

\section{Recommendations for Research}

The findings of this study were based on the completion of a survey of K-5 public elementary principals in West Virginia and their reading instructional leadership practices. Future studies and additional research would provide a further understanding of the issues related to reading instructional leadership. Although, Reading First was concluded during the school year 2010-2011, quality research must be considered as new programs are initiated to address reading instructional leadership practices at the national, state and local levels. Six recommendations are offered for further research: 
1) Researchers could consider a more in-depth investigation of individual student growth using a quantitative design to specifically examine reading achievement rather than overall student achievement, using DIBELS data rather than WESTEST information. This would provide a clearer picture of individual student reading growth.

2) Researchers could duplicate this study to examine the teacher perceptions of building level principals, along with principal self-reports regarding reading instructional leadership practices. This would increase the reliability of the research results, noting the concerns of selfreported data. Cook and Campbell (1979) have pointed out that subjects (a) tend to report what they believe the researcher expects to see, or (b) report what reflects positively on their own abilities, knowledge, beliefs, or opinions.

3) Future researchers should consider a study consisting of quantitative and qualitative designs of any large scale national, state, or local level effort including principal reading instructional leadership practices as a component of improving reading instruction. The results are important for consideration in sustainability of continuous improvement of reading instructional leadership.

4) This study could be replicated; however, based on the limitations, future research may include comparisons of student achievement data from schools with similar demographics, considering the percentage of low SES, special education students or total student population in the selection of the non-Reading First schools. Furthermore, in this case, future studies should not use random selection without control variables.

5) Comparative research study could be utilized in order to surmise the results from similar studies using Reading First and non-Reading First schools student achievement data, practices, and beliefs. 
6) Comparative research studies could be utilized to determine the impact of effective reading leadership strategies on student achievement. Counties may consider changing principal assignment; re-assigning principals from high performing schools to schools with low performance and then determining the impact on student achievement. 


\section{References}

Andrews, R., Soder, R., \& Jacoby, D. (1986). Student achievement and principal leadership. Educational Leadership. 44 (6), 9-11.

Andrews, R., \& Soder, R. (1987). Student achievement and principal leadership Educational Leadership, 44J (6), 9-11.

Austin, N. (1985). A Passion for excellence. New York: Warner Books, Inc.

Bailey, G., \& Lumley, D. (1997). Technology staff development program-A leadership source book for school administrators. Bloomington Ind: National Educational Service.

Banks, J. A. (1991). Teaching strategies for ethnic studies. Boston: Allyn and Bacon.

Beck, Isabel L. (2006). Making sense of phonics. New York: The Guilford Press.

Beers, K. 2002. When kids can't read, What teachers can do: A guide for teacher 612. Portsmouth, NH: Heinemann.

Blasé, J., \& Blasé J. (2000). Effective instructional leadership: Teachers' perspectives on how principals promote teaching and learning in schools. Journal of Educational Administration, 38 (2), 130-141.

Bolman, L.G. \& Deal, T.E. (1999). Four steps to keeping change efforts heading in the right direction. Journal for Quality and Participation, 22, (3) 6.

Bolman, L. G. \& Deal, T.L. (2006). The wizard and the warrior: Leading with passion and power. SanFrancisco: Jossey-Bass.

Bonham, S.W., Titus, A., Beichner, \& R.J., Martin, L., (2000). Education research using web based assessment systems. Journal of Research on Computing in Education. 33 (1), 28-44. 
Bossert, S., Dwyer, D., Rowan, B., \& Lee, G. (1982). The instructional management role of the principal. Educational Administration Quarterly, 1 (3), 34-64.

Boyan, N. (1988). Handbook of research in educational administration. New York: Longman.

Braughton, R., \& Riley, J. (1991). The relationship between principals' knowledge of the reading process and elementary school reading achievement. (ERIC Document Reproduction Service No. ED. 341952).

Brookover, W.B. (1987). High expectations in effective schools. Paper presented at the West Virginia Principals' Academy. Huntington: WV.

Brookover, W.B., \& Lezotte L. (1979). Changes in school characteristics coincident with changes in student achievement. East Lansing, Mich.: Michigan State University, Institute for Research on Teaching.

Campbell, J., Kyriakides, L., Muijs, D., \& Robinson, W. (2004). Assessing teacher effectiveness: Developing a differentiated model. London: Routledge Falmer.

Carter, S.C. (2000). No excuses: Lessons from 21 high-performing, high-poverty schools. Washington, DC: Heritage Foundation.

Chemers, M.M. (2002). Cognitive, social, and emotional intelligence of transformational leadership: Efficacy and effectiveness. Multiple Intelligences and Leadership, (pp. 105118) NJ: Lawrence Eribaum Associates.

Coleman, J.S., Campbell, E., Hobson, C, McPartand, J., Mood. A., Weinfeld, F., \& York, R. (1966). On equality of educational opportunity. Washington, DC: U.S. Office of Education, National Center for Education Statistics.

Collins, J. (2001). Good to be great. New York: Harper Collins. 
Conaty, Joseph. (2008). Reading First.

http://www.edweek.org/ew/articles/2008/08/08/45read.h27.html.

Cook, T. D. \& Campbell, D.T. (1979) Quasi-experimentation: Design and analysis issues. Boston: Houghton Mifflin Co.

Cuban, L. (1984). Transforming the frog into a prince: Effective school research, policy, and practice at the district level. Harvard Educational Review 54 (2), 129-151.

Cummins, C. (2006). Understanding and implementing reading first initiatives. Newark, DE: International Reading Association.

Daggett, B. (2004). Views you can use. Retrieved on November 1, 2009, from www.LeaderEd.com.

Davies, K. (2009). The Perceptions of Practicing West Virginia K-3 Reading Teachers of Working with Reading First Coaches in Title I Distinguished Schools. Unpublished doctoral dissertation, Morgantown: West Virginia University.

DeBevoise, W. (1984). Synthesis of research on the principal as instructional leader. Educational Leadership, 41 (5), 14 - 20.

Doan, M.F., \& Doan, R.L. (1984). A comparison of elementary principals' and teachers' perceptions of reading instruction and staff development. (ERIC Document Reproduction Service No. ED313329)

Dufour, R. (2002). The learning-centered principal. Educational Leadership. 59, (8) 12-15.

Edmonds, R. (1980). Some schools work and more can. Social Policy, 17 (5), 17-18.

Edmonds, R. (1982). Programs of school improvement: An overview. Educational Leadership, $40(3), 4-11$. 
Ferrandino, V.L., \& Tirozzi, G.N. (2001). The principal, keystone of a high-achieving school: Attracting and keeping the leaders we need. National Association of Elementary Principals. (ER1C Document Reproduction Service No.ED953576).

Finn, C, Petrilli, M, \& Julian, L. (2006). The state of state standards 2006. Thomas B. Fordham Institute Advancing Educational Excellence, Retrieved on November 2, 2009 from http://www/edexcellence.net/detail/new.cfm?news id=358.

Firebaugh, G. (1997). Analyzing repeated surveys. CA: Sage Publications.

Fraenkel, J. \& Wallen N. (2000) How to design and evaluate research in education. Columbus: McGraw-Hill.

Fullan, M. (2001). The new meaning of educational change. New York: Teachers College Press. Fullan, M. (2004). Leading in a culture of change. San Francisco: Jossey-Bass.

Gay, L.R., Mills, G.E., \& Airasian, P. (2006). Educational research, Competencies for analysis and applications. Upper Saddle River NJ: Pearson Education, Inc.

Gentry, J.R. (1999). The Literacy Map. Canada: Mondo Publishing.

Glickman, CD., (1987). Instruction improvement and the K-8 principal. NASSP Bulletin 5 (4), $2-8$.

Glickman, CD., Gordon, S.P., \& Ross-Gordon, J.M. (1995). Supervision of instruction (3 ${ }^{\text {rd }}$ ed). Needham Heights, MA: Simon \& Schuster Company.

Greenfield, W. (1987). Instructional leadership. Boston: Allyn \& Bacon.

Guskey, T.R. (2000). Evaluating professional development. Thousand Oaks: Corwin Press.

Hackman, M. Z. \& Johnson, C E. (2000). Leadership A communication perspective. Prospect Heights, Illinois: Waveland Press, Inc. 
Hall, S. L. (2006). I've DIBEL 'd, Now what? Sopris West Educational Services. New York.

Hallinger, P. (2001). A review of two decades of research on the principalship using the Principal Instructional Management Rating Scale. Paper presented at the Annual Meeting of the American Educational Research Association. Seattle, WA.

Hallinger, P., \& Heck, R. (1996). The principal's role in school effectiveness: an assessment of methodological progress, 1980-95. in Leithwood, K, Chapman, J., Corson, D., Hallinger, P., Hart, A (Eds.), International Handbook of Educational Leadership and Administration, Kluwer, Dordrecht, 723-83.

Hallinger, P. \& Murphy, J. (1983). Effective high schools: What are the common characteristics? NASSP Bulletin, 69 (477), 18 -22.

Heck, R., Larsen, T., \& Marcoulides, G. (1990). Principal leadership and school achievement: Validation of a causal model. Paper presented at the Annual Meeting of the American Educational Research Association, Boston.

Heck, R., \& Marcoulides, G. (1992). Principal assessment: Conceptual problem, methodological problem or both? Peabody Journal of Education, 68 (1), 124-144.

Hillard, L. C, Guglielmino, L. (2002). Promoting reading improvement: A case study of exemplary elementary principals. (ERIC Document Reproduction Service No. ED. 795 660)

Hinkle, D., Wiersma, W., \& Jurs, S. (2003), Applied statistics for the behavioral sciences. New York: McGraw-Hill

Howard, E, Howell, B, \& Brainard, E. (1987). Handbook for conducting school climate improvement projects. The Phi Delta Kappa Educational Foundation, Bloomington, Indiana. 
Hoyle, J. R., (1988). The 21st century superintendent: A great motivator. Paper presented at the Annual Meeting of the American Association of School Administrators, Las Vegas, NV.

Johns, J. L. \& Berglund, R. L. (2002). Fluency. Dubuque, IA: Kendall/Hunt Publishing Company.

Lashway, L. (2002). Trends in school leadership. Eric Digest, 1-3.

Lay, Christine. (2007). dissertation Leadership responsibilities needed to implement a response to implement a response to intervention model. (Doctoral dissertation, Wiedner University, 2007). Dissertation Abstracts International, $6901 \mathrm{~A}$

Lazar, J., \& Preece, J. (1999). Designing and implementing web-based surveys. Journal of Computer Information Systems, 39(4), 63-67.

Learning Point Associates. (2004). Reading first instructional leadership for principals. Naperville, IL: Learning Point Associates.

Leithwood, K. \& Jantzi, D. (2000). The relative effects of principal and teacher sources of leadership on student engagement with school. Educational Administration Quarterly. 35 (4), 679-706.

Lezotte, L. (1989) School improvement based on the effective schools research. International Journal of Educational Research 13, (7), 815-825.

Lezotte, L.W. (1999). Creating the total quality effective school Okemos, MI: Effective Schools Products, Ltd.

Lezotte, L. (2001). Revolutionary and evolutionary: The effective schools movement. Okemos, ML: Effective Schools Products, Ltd.

Lezotte, L.W. (2004). Learning for all Okemos, MI: Effective School products, Ltd. 
Lezotte, L.W. \& McKee, K. M. (2002) Assembly required. Okemos, MI: Effective School Products, Ltd.

Lezotte, L.W., \& Pepperl, J.C. (1999). The effective schools' process: A proven path to learning for all Okemos, MI: Effective Schools Products, Ltd.

Lieberman, A. \& Miller, L. (1984). Teachers, their world and their work Alexandria, Virginia: Association for Supervision and Curriculum Development.

McEwan, E. K. (2003). 7 Steps to effective instructional leadership. Thousand Oaks, CA: Corwin Press, Inc.

Marzano, RJ. (1998). Rethinking test and performance task. School Administrator, 11 (55), 1012.

Marzano, R.J. (2000). Transforming classroom grading. Alexandria, VA: Association for Supervision and Curriculum Development.

Marzano, R.J. (2003). What works in schools: Translating research into action. Alexandria, VA: Association for Supervision and Curriculum Development.

Marzano, R.J., Gaddy, B.B., \& Dean, C. (2000). What works in classroom instruction? Aurora, CO: Mid-continent Research.

Marzano, R.J., McNulty, B.A. \& Waters, T. (2005). School leadership that works: From research to results. Alexandria, VA: Association for Supervision and Curriculum Development.

Motley, R., \& McNinch, G. (1984). The principal and the reading program. Reading World, 124 (2), 81-86.

Murnane, Richard J., Maynard, R. \& Ohls, J. (1981). Home resources and children's achievement Review of Economics and Statistics, 63, 369-377. 
National Association of State Directors of Special Education . (2005). Response to intervention: Policy considerations and implementation. Alexandria, VA: NASDSE, Inc.

National Center for Educational Evaluation and Regional Assistance (2010). Reading First Impact Study: Interim Report, http:/ies.ed.gov/ncee/pubs/20084016/index.asp. USDE, Washington, DC.

National Commission on Excellence in Education (1983). A nation at risk: The imperative for educational reform. A report to the nation and the secretary of education, United States Department of Education. Washington, D.C.; U.S. Department of Education. National Council of Teachers of English. (2002). Annual position statement: On the Reading First initiative. Retrieved February 13, 2008, from http://www.ncte.Org/about/over/positions/categorv/read/1 07475 .htm.

No Child Left Behind Act of 2001, Pub. L. No. 107-110,115 Stat. 1425 (2002).

No Child Left Behind Compliance Insider. (2008, December). IES: Reading first helps decoding, not comprehension. Horsham, PA: LRP Publications.

Noddings, N. (1991). The gender issue Education LeadershipA9 (4), 65-70.

Northup, A. (2000). National reading panel press releases Retrieved on March 2, 2009 from www.frontlinesphonics.com/pressrelease1.html-29k-Cached

Paine, S. L., (2002). The relationship of superintendent instructional leadership behavior and student achievement in high performing high schools that work network public high schools in West Virginia. Morgantown, West Virginia University.

Phillips, D. T. (1992). Lincoln on leadership. New York: Warner Books, Inc.

Pitner, N. (1988). Handbook of research in educational administration. New York: Longman.

Porter, M. (2001). Reading instructional leadership: A survey of middle level principals in West Virginia schools. Dissertation, Morgantown, West Virginia University. 
Oppermann, M. (1995). E-mail survey: Potentials and pitfalls. Marketing Research, 1 (3), 28.

Rand Corporation. (2002). a million random digits with 100,000 normal deviates. The Free Press, Glencoe, ILL.

Rinehart, J.S. \& Short, P.M. (1994). Viewing reading recovery as a restructuring phenomenon. Journal of School Leadership, 1(4), 379-399.

Saris, W.E. (1991). Computer-assisted interviewing. New Berry: Sage.

Schatschneider, F., Foorman, F., \& Mehta, F. (1999). The dimensionality of phonological awareness: An application of item response theory. Journal of Educational Psychology, $91(3), 439-449$.

Scheerens, J. \& Bosker, R. (1997) The Foundations of educational effectiveness. Oxford, Pergamon Press.

Schmidt, W.C. (1997). World-wide web survey research: benefits, potential problems, and solutions. Behavior Research Methods, Instruments and Computers, 29(2), 274-279.

Schmoker, M. (2007). Radically redefining literacy instruction: An immense opportunity. Phi Delta Kappan. 88, (7) 488-493.

Senge, P. (1990). The fifth discipline: The art and practice of the learning organization. London: Doubleday.

Sergiovanni, T. (1984). Value- added leadership: How to get extraordinary performances in schools. New York: Harcourt-Brace Jovanovich.

Sergiovanni, T. (1992). Moral leadership. San Francisco: Jossey-Bass.

Smith, W. F. \& Andrews, R. L. (1989). Instructional leadership: How principals make a difference. Alexandria, VA: Association of Supervision and Curriculum Development. 
Southworth, G. (2002). Instructional leadership in schools: Reflections and empirical evidence. School Leadership \& Management, 22, (1) 73-92.

Spillane, J. (2006). Distributed leadership. San Francisco: Jossey-Bass.

Spillane, J., Halverson, R., \& Diamond, J. (2000). Toward a theory of leadership practice: A distributed perspective. Evanston, IL: Institute for Policy Research.

Suskie, L. (1996). Survey research: What works for the institutional researcher? Itacha, NY: Northeast Association for Institutional Research.

Swoboda, S.J., Muehlberger, N., Weitkunat, R. \& Schneeweiss, S. (1997). Web-based surveys by direct mailing: An innovative way of collecting data. Social Science Computer Review, 15(3).

Taylor, A., Valentine, B., \& Jones, M. (1985). What research says about effective school, Number I. West Haven, CT: National Education Association.

Teddlie, C \& Reynolds, D, (2000), The international handbook of school effectiveness research. London: Falmer Press.

United States Department of Education. (1999). The Reading Excellence Act. Retrieved on March 6, 2008, from http://www.ed.gov/inits/FY99/1 -read.html

United States Department of Education. (2002, April). Guidance for the Reading First Program. Washington, DC: Author.

United States Department of Education. (2006, July). Reading First implementation evaluation: Interim report. Washington, D.C.: Education Publications Center.

United States Department of Education (2007). Reading First awards. Retrieved January 8, 2008, from http://www.ed.gov/news/pressreleases/2003/07/07212003.html 
United States Department of Education (April 2008).Reading First Impact Study Interim Report: Washington, D.C.: Institute of Education Science.

United States Department of Education (2008, October). Reading First implementation evaluation: Final report. Washington, D.C.: Education Publications Center.

United States Department of Health and Human Services. (2000, December). Report of the National Reading Panel: Teaching children to read. (NIH Publication No. 004754). Washington, D.C.

Vaughn, S, \& Thompson-Linan, S. (2004). Research-based methods of reading instruction grades K-3. Alexandria, VA: Association of Supervision and Curriculum.

Walls, R. T. (personal communication, Fall 2010).

Waters, T., \& Cameron, G. (2007). The balanced leadership framework: Connecting vision with action. Aurora, CO., McRel.

Web Center for Social Research. (2006). Research methods knowledge base. Retrieved December 20, 2008, from http://socialresearchmethodsnet.

West Virginia Department of Education. (2002). West Virginia Reading First grant application. Charleston, WV: Author.

West Virginia Department of Education. (2008). Title I distinguished schools. Retrieved October 4, 2008, from http://wvde.state.wv.us/titlei/distinguished.html.

Yousuf, M (2007) Practical Assessment Research \& Evaluation, 12, (4), 1-6.

Yun, G.W., \& Trumbo, C.W. (2000, September). Comparative response to a survey executed by post, e-mail, \& web form. Journal of Mediated Communication.

Zimmermann, S. \& Hutchins, C. (2003). 7 Keys to comprehension. New York: Three River Press. 


\section{APPENDIX A \\ SURVEY OF PUBLIC ELEMENTARY PRINCIPALS IN WEST VIRGINIA: READING INSTRUCTIONAL LEADERSHIP}

For each statement below, circle the number that most accurately describes how often you perform each of the follow to help student reading achievement for children in your school.

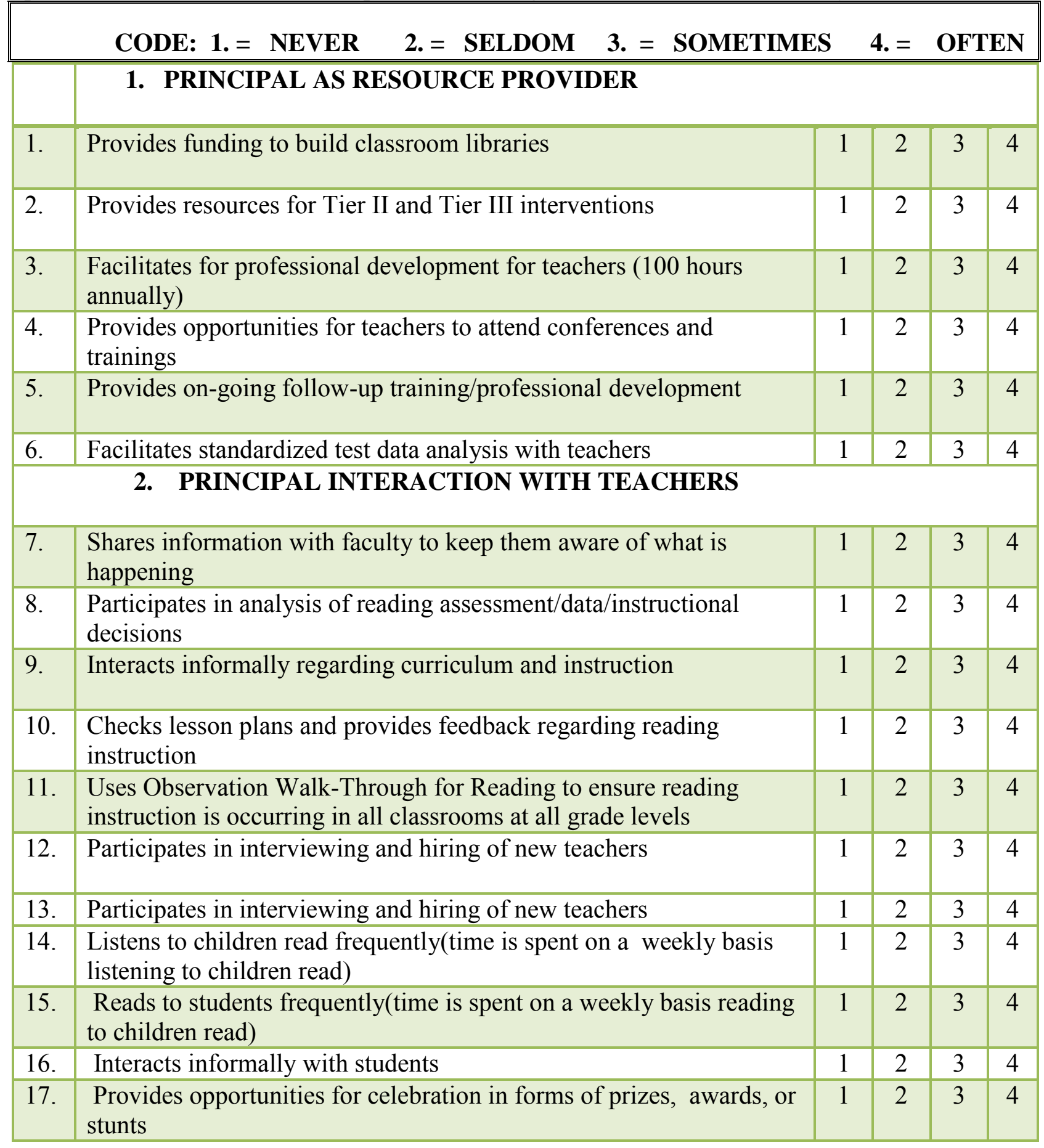




\section{PRINCIPAL ASSURANCE OF SCHOOL CLIMATE CONDUCIVE TO LITERACY DEVELOPMENT}

\begin{tabular}{|l|l|l|l|l|l|}
\hline 18. & Protects the 90/120 minute reading block & 1 & 2 & 3 & 4 \\
\hline 19. & $\begin{array}{l}\text { Special activities that focus on instructional goals tested on the } \\
\text { WESTEST }\end{array}$ & 1 & 2 & 3 & 4 \\
\hline 20 & Reading/literature courses for students in all grades & 1 & 2 & 3 & 4 \\
\hline 21. & Tier II/Tier III for students & 1 & 2 & 3 & 4 \\
\hline 22 & Peer/parent tutoring programs & 1 & 2 & 3 & 4 \\
\hline 23. & Interaction among faculty & 1 & 2 & 3 & 4 \\
\hline 24. & Displays student work in classrooms and halls & 1 & 2 & 3 & 4 \\
\hline 25. & Voluntary reading by students upon task completion & 1 & 2 & 3 & 4 \\
\hline 26 & Reading to student by guests/parents & 1 & 2 & 3 & 4 \\
\hline 27. & Assures School/classroom incentive programs for reading & 1 & 2 & 3 & 4 \\
\hline
\end{tabular}

\section{PROFFESSIONAL DEVELOPMENT}

For each statement below, check either YES or NO to indicate whether each of the following has helped you acquire the skills and information you need as the reading instructional leader in your school.

\begin{tabular}{|l|l|c|c|}
\hline 28. & Undergraduate courses in reading & YES & NO \\
\hline 29. & If yes, did they help & YES & NO \\
\hline 30. & Graduate courses in reading you took, if any & YES & NO \\
\hline 31. & If yes, did they help & YES & NO \\
\hline 32. & $\begin{array}{l}\text { Professional reading of journal/articles pertaining to reading research } \\
\text { and instruction }\end{array}$ & YES & NO \\
\hline 33. & $\begin{array}{l}\text { Professional development for Reading First schools at the school } \\
\text { level }\end{array}$ & YES & NO \\
\hline 34. & Training from WVDE pertaining to Reading First & YES & NO \\
\hline 35. & RESA level training in the area of reading & YES & NO \\
\hline 36. & Reading content presented during Principal‘s Academy & YES & NO \\
\hline 37. & Experiences during teaching & YES & NO \\
\hline 38. & Experiences during principalship & YES & NO \\
\hline 39. & Interactions with teachers/reading specialists & YES & NO \\
\hline
\end{tabular}




\section{DEMOGRAPHIC}

Please complete the following information about yourself or your school.

40 . Number of years in current position

41. Number of years with a Reading First school

42. What is your gender Male Female

43. Number of years you have taught reading

44. Number of reading courses taken at the undergraduate or graduate level

45. Number of years experience as a principal

46. Number of years at Elementary level (K-4)

47. Number of years at Middle School level (5-8)

48. Number of years at Secondary level (9-12)

49.. As an average, how many hours of your day is spent working with instruction? Less than 1 hour per day 1-3 hours per day 4 or more hours per day 50. Would you like to have your email address included in a drawing for a $\$ 75.00$ gift certificate for Stone Jackson Resort? YES NO 


\author{
Appendix B \\ Consent to Participate in Research \\ Principal Letter of Invitation in Research Study
}

March 15, 2010

Dear Principal:

As a partial fulfillment of the leadership studies doctoral program at West Virginia University, I am required to conduct a research-based study focused on improving educational leadership practice. The purpose of my study is to determine if there is a connection between principal professional development and student achievement. The benefit will include valuable information for both principals and those who prepare programs for educational leaders. In addition, it will help you to identify best practices as they relate to your choice in continuing education, ultimately, to improve reading and increase student achievement.

I am requesting your participation in the study as a principal of one of 84 elementary schools. The purpose of this letter is to ask for your participation in the study by completing an electronic survey that will take approximately 10 minutes of your time. Although strongly encouraged, participation is voluntary and there are no consequences for non-participation. All survey responses will be kept confidential and all individual identifying information will be reviewed only by the researcher.

I sincerely appreciate your consideration regarding participation in this study. If you have further questions contact me at rjlewis@access.k12.wv.us or (304) 822-3528. Thank you for your assistance this matter.

Sincerely,

Mrs. Robin Lewis

Doctoral Candidate

Department of Educational Leadership

Dr. Helen Hazi

Committee Chairperson

Educational Leadership

West Virginia University 
Appendix C

Survey Instrument Parallel with International Reading Association Standards for Reading Professionals

\begin{tabular}{|c|c|c|c|c|c|c|c|c|c|c|c|c|c|c|c|c|c|c|c|}
\hline \multirow[t]{2}{*}{ SURVEY ITEMS } & \multicolumn{4}{|c|}{$\begin{array}{l}\text { IRA } \\
\text { STANDARD } 1\end{array}$} & \multicolumn{3}{|c|}{$\begin{array}{l}\text { IRA } \\
\text { STANDARD } 2\end{array}$} & \multicolumn{4}{|c|}{$\begin{array}{l}\text { IRA } \\
\text { STANDARD } 3\end{array}$} & \multicolumn{4}{|c|}{$\begin{array}{l}\text { IRA } \\
\text { STANDARD } 4\end{array}$} & \multicolumn{4}{|c|}{$\begin{array}{l}\text { IRA } \\
\text { STANDARD } 5\end{array}$} \\
\hline & 1.1 & 1.2 & 1.3 & 1.4 & 2.1 & 2.2 & 2.3 & 3.1 & 3.2 & 3.3 & 3.4 & 4.1 & 4.2 & 4.3 & 4.4 & 5.1 & 5.2 & 5.3 & 5.4 \\
\hline $\begin{array}{l}\text { PROVIDES FUNDS } \\
\text { FOR CLASSROOM } \\
\text { LIBRARY }\end{array}$ & & $\mathrm{x}$ & $\mathrm{x}$ & $\mathrm{x}$ & $\mathrm{x}$ & $\mathrm{x}$ & $\mathrm{x}$ & & & & & $\mathrm{x}$ & $\mathrm{x}$ & $\mathrm{x}$ & $\mathrm{x}$ & $\mathrm{x}$ & & & $\mathrm{x}$ \\
\hline $\begin{array}{l}\text { PROVIDES } \\
\text { RESOURCES FOR } \\
\text { TIER II/III READING } \\
\text { MATERIALS. } \\
\end{array}$ & $\mathrm{x}$ & $\mathrm{x}$ & $\mathrm{x}$ & $\mathrm{x}$ & $\mathrm{x}$ & $\mathrm{x}$ & $\mathrm{x}$ & $\mathrm{X}$ & $\mathrm{x}$ & $\mathrm{X}$ & $\mathrm{x}$ & $\mathrm{x}$ & & $\mathrm{x}$ & $\mathrm{x}$ & $\mathrm{x}$ & $\mathrm{x}$ & $\mathrm{X}$ & $\mathrm{x}$ \\
\hline $\begin{array}{l}\text { PROVIDES AND } \\
\text { ATTENDS (100 HOURS } \\
\text { PER YEAR) } \\
\text { PROFESSIONAL } \\
\text { DEVELOPMENT FOR } \\
\text { TEACHERS AND } \\
\text { FOLLOW-UP. }\end{array}$ & $\mathrm{x}$ & $\mathrm{x}$ & $\mathrm{x}$ & $\mathrm{x}$ & $\mathrm{x}$ & $\mathrm{x}$ & $\mathrm{x}$ & $X$ & $\mathrm{x}$ & $X$ & $\mathrm{x}$ & $\mathrm{x}$ & & $\mathrm{x}$ & $\mathrm{x}$ & $\mathrm{x}$ & $\mathrm{x}$ & $X$ & $\mathrm{x}$ \\
\hline $\begin{array}{l}\text { PROVIDES/EXPLAINS } \\
\text { DIBELS, AND } \\
\text { STANDARDIZED } \\
\text { TEST DATA. } \\
\end{array}$ & $\mathrm{x}$ & $\mathrm{x}$ & $\mathrm{x}$ & $\mathrm{x}$ & $\mathrm{x}$ & $\mathrm{x}$ & $\mathrm{x}$ & $\mathrm{X}$ & $\mathrm{x}$ & $\mathrm{X}$ & $\mathrm{x}$ & $\mathrm{x}$ & & & $\mathrm{x}$ & & $\mathrm{x}$ & $\mathrm{X}$ & $\mathrm{x}$ \\
\hline $\begin{array}{l}\text { PROVIDES/EXPLAINS } \\
\text { DIBELS, AND } \\
\text { STANDARDIZED } \\
\text { TEST DATA. } \\
\end{array}$ & $\mathrm{x}$ & $\mathrm{x}$ & $\mathrm{x}$ & $\mathrm{x}$ & $\mathrm{x}$ & $\mathrm{x}$ & $\mathrm{x}$ & & $\mathrm{x}$ & & $\mathrm{x}$ & $\mathrm{x}$ & $\mathrm{x}$ & $\mathrm{x}$ & $\mathrm{x}$ & $\mathrm{x}$ & $\mathrm{x}$ & $\mathrm{X}$ & $\mathrm{x}$ \\
\hline $\begin{array}{l}\text { SHARES ARTICLES, } \\
\text { JOURNALS, BOOKS, } \\
\text { ETC. WITH FACULTY. }\end{array}$ & $\mathrm{x}$ & $\mathrm{x}$ & $\mathrm{x}$ & $\mathrm{x}$ & $\mathrm{x}$ & $\mathrm{x}$ & $\mathrm{x}$ & $\mathrm{X}$ & $\mathrm{x}$ & $\mathrm{X}$ & $\mathrm{x}$ & $\mathrm{x}$ & $\mathrm{x}$ & $\mathrm{x}$ & $\mathrm{x}$ & $\mathrm{x}$ & $\mathrm{x}$ & $X$ & $\mathrm{x}$ \\
\hline $\begin{array}{l}\text { COORDINATES } \\
\text { ANALYSIS OF TEST } \\
\text { DATA/GOAL } \\
\text { DEVELOPMENT. }\end{array}$ & $\mathrm{x}$ & $\mathrm{x}$ & $\mathrm{x}$ & $\mathrm{x}$ & $\mathrm{x}$ & $\mathrm{x}$ & $\mathrm{x}$ & $\mathrm{X}$ & $\mathrm{x}$ & $\mathrm{X}$ & $\mathrm{x}$ & $\mathrm{x}$ & $\mathrm{x}$ & $\mathrm{x}$ & $\mathrm{x}$ & $\mathrm{x}$ & $\mathrm{x}$ & $X$ & $\mathrm{x}$ \\
\hline $\begin{array}{l}\text { OBSERVES } \\
\text { TEACHING/PROVIDE } \\
\text { S FEEDBACK. }\end{array}$ & $\mathrm{x}$ & $\mathrm{x}$ & $\mathrm{X}$ & $\mathrm{x}$ & $\mathrm{x}$ & $\mathrm{x}$ & $\mathrm{x}$ & $X$ & $\mathrm{x}$ & $\mathrm{x}$ & $\mathrm{x}$ & $\mathrm{X}$ & $\mathrm{x}$ & $\mathrm{x}$ & $\mathrm{x}$ & $\mathrm{x}$ & $\mathrm{x}$ & $\mathrm{X}$ & $\mathrm{x}$ \\
\hline $\begin{array}{l}\text { LISTENS TO } \\
\text { STUDENTS READ } \\
\text { AND READS TO } \\
\text { STUDENTS. }\end{array}$ & $\mathrm{x}$ & $\mathrm{x}$ & $\mathrm{x}$ & $\mathrm{x}$ & $\mathrm{x}$ & $\mathrm{x}$ & $\mathrm{x}$ & $X$ & $\mathrm{x}$ & & $\mathrm{x}$ & $\mathrm{x}$ & $\mathrm{x}$ & $\mathrm{x}$ & $\mathrm{x}$ & $\mathrm{x}$ & $\mathrm{x}$ & & $\mathrm{x}$ \\
\hline $\begin{array}{l}\text { READS TO } \\
\text { STUDENTS. }\end{array}$ & $\mathrm{x}$ & $\mathrm{x}$ & $\mathrm{x}$ & $\mathrm{x}$ & $\mathrm{x}$ & $\mathrm{x}$ & $\mathrm{x}$ & & $\mathrm{x}$ & $\mathrm{x}$ & & $\mathrm{x}$ & $\mathrm{x}$ & $\mathrm{x}$ & $\mathrm{x}$ & $\mathrm{x}$ & & & $\mathrm{x}$ \\
\hline $\begin{array}{l}\text { INTERACTS } \\
\text { INFORMALLY WITH } \\
\text { STUDENTS. } \\
\end{array}$ & $\mathrm{x}$ & $\mathrm{x}$ & $\mathrm{x}$ & $\mathrm{x}$ & $\mathrm{x}$ & $\mathrm{x}$ & $\mathrm{x}$ & $\mathrm{X}$ & $\mathrm{x}$ & $\mathrm{x}$ & & $X$ & $\mathrm{x}$ & $\mathrm{x}$ & $\mathrm{x}$ & $\mathrm{x}$ & $\mathrm{x}$ & $\mathrm{X}$ & $\mathrm{x}$ \\
\hline $\begin{array}{l}\text { PROTECTS THE } 120 \\
\text { MINUTE READING } \\
\text { BLOCK. }\end{array}$ & $\mathrm{x}$ & $\mathrm{x}$ & $\mathrm{x}$ & $\mathrm{x}$ & $\mathrm{x}$ & $\mathrm{x}$ & $\mathrm{x}$ & $\mathrm{X}$ & $\mathrm{x}$ & $\mathrm{x}$ & $\mathrm{x}$ & $\mathrm{x}$ & $\mathrm{x}$ & $\mathrm{x}$ & $\mathrm{x}$ & $\mathrm{x}$ & $\mathrm{x}$ & $\mathrm{X}$ & $\mathrm{x}$ \\
\hline $\begin{array}{l}\text { DISPLAYS OF } \\
\text { STUDENT WORK IN } \\
\text { CLASSROOMS AND } \\
\text { HALLS. }\end{array}$ & $\mathrm{x}$ & $\mathrm{x}$ & $\mathrm{x}$ & $\mathrm{x}$ & $\mathrm{x}$ & $\mathrm{x}$ & $\mathrm{x}$ & $\mathrm{X}$ & & & $\mathrm{x}$ & $\mathrm{x}$ & $\mathrm{x}$ & $\mathrm{x}$ & $\mathrm{x}$ & $\mathrm{x}$ & & $\mathrm{X}$ & $\mathrm{x}$ \\
\hline $\begin{array}{l}\text { SCHOOL/CLASSROO } \\
\text { M INCENTIVE } \\
\text { PROGRAMS FOR } \\
\text { READING. }\end{array}$ & $\mathrm{x}$ & $\mathrm{x}$ & $\mathrm{x}$ & $\mathrm{x}$ & $\mathrm{x}$ & $\mathrm{x}$ & $\mathrm{x}$ & $\mathrm{X}$ & & & $\mathrm{x}$ & $\mathrm{x}$ & $\mathrm{x}$ & $\mathrm{x}$ & $\mathrm{x}$ & $\mathrm{x}$ & & $X$ & $\mathrm{x}$ \\
\hline
\end{tabular}


Appendix D

Standards for Reading Professionals—Revised 2003

\section{A Reference for the Preparation of Educators in the United States, Developed by the Professional Standards and Ethics Committee of the International Reading Association}

Copyright (C) 2004 by the International Reading Association, Inc.

Please note: This online version of the current standards document reproduces the core content of the printed version, and is intended for browsing purposes. The printed version contains additional resources, including a glossary, list of related websites, description of review dissemination, contact information, and the IRA code of ethics.

For additional information about these standards and their application within educational settings, contact the Professional Standards and Ethics Committee or the Research Division of the International Reading Association, 800 Barksdale Road, PO Box 8139, Newark, DE 197148139, USA; tel. +302-731-1600.

\section{Acknowledgments}

Standards for Reading Professionals_-Revised 2003 [Standards 2003] was developed by a task force of the Professional Standards and Ethics Committee of the International Reading Association. Many individuals were involved in the revision of the Standards. It was a long and difficult task, as Task Force members considered and reviewed hundreds of contributing comments from members of the education community.

In particular, IRA wishes to express its gratitude to the cochairs, Barbara Chesler and Lynn Romeo, for their unfailing dedication to this revision; the numerous hours spent drafting and revising the standards; the weekend meetings and conference calls; and for their patience, good humor, and congenial dispositions during this entire project.

IRA would also like to recognize the contributions of all the members of the Task Force who put time and effort into writing and reviewing drafts, attending meetings, and wading through hundreds of comments from contributors. We want to express thanks to Cathy Roller for her leadership and direction and to Gail Keating for her general management of the project in keeping the Task Force motivated, meeting deadlines, and moving the process forward.

\section{Standards Task Force}

Barbara Chesler, cochair Longwood University, Virginia Lynn Romeo, cochair Monmouth University, New Jersey

Allen Berger Miami University, Ohio

Jeri Gillin Providence College, Rhode Island

Daniel R. Hittleman Queens College, New York 
William Earl Smith Ohio University, Ohio

Gail Keating, Ex Officio International Reading Association, Delaware

Cathy Roller, Ex Officio International Reading Association, Delaware

In revising these Standards we sought to reflect the many different voices, interests, and concerns of our diverse contributors. We would like to thank all those in the education profession who contributed to this revision by reviewing the drafts developed during the revision period. Their constructive comments are reflected in this document.

Lastly, we would also like to acknowledge the support of IRA's Electronic Services Department, in particular David Roberts and Ed Broadbelt, in getting the draft Standards 2003 on IRA's website.

Standards for Reading Professionals is revised periodically. The following individuals served on the Professional Standards and Ethics Committee during the three-year revision period and offered extensive contributions.

\section{2-2003}

Barbara J. Chesler, cochair, Longwood University, Virginia

Lynn Romeo, cochair, Monmouth University, New Jersey

Charline Barnes, University of Northern Iowa, Iowa

Anita Corey, Radford University, Virginia

Jeri Gillin, Providence College, Rhode Island

Sherry E. Kragler, Ball State University, Indiana

Jill D. Lewis, New Jersey City University, New Jersey

Hanfu Mi, State University of New York, Oneonta, New York

Diane J. Quatroche, Indiana State University, Indiana

Mary E. Robbins, Sam Houston State University, Texas

William Earl Smith, Ohio University, Ohio

Adrienne Andi Sosin, Adelphi University, New York

Karen J. Sweeney, Wayne State College, Nebraska

Allen Berger, Ex Officio, Miami University, Ohio

Gail Keating, Ex Officio, International Reading Association, Delaware

Cathy Roller, Ex Officio, International Reading Association, Delaware

\section{1-2002}

Barbara J. Chesler, cochair, Longwood University, Virginia

Lynn Romeo, cochair, Monmouth University, New Jersey

Paula Boxie, Miami University, Ohio

Diane E. Bushner, Salem State College, Massachusetts

Jeri Gillin, Providence College, Rhode Island

John J. Hobe, Armstrong Atlantic State University, Georgia

Adrienne Andi Sosin, Pace University, New York

Allen Berger, Ex Officio, Miami University, Ohio

Gail Keating, Ex Officio, International Reading Association, Delaware

Cathy Roller, Ex Officio, International Reading Association, Delaware 


\section{0-2001}

Allen Berger, chair, Miami University, Ohio

Paula Boxie, Miami University, Ohio

Diane E. Bushner, Salem State College, Massachusetts

Barbara J. Chesler, Longwood College, Virginia

Cay Evans, Louisiana State University, Louisiana

Margaret Genisio, University of Wisconsin, Wisconsin

Jeri Gillin, Providence College, Rhode Island

John J. Hobe, Armstrong Atlantic State University, Georgia

Bonnie A. Konopak, University of Northern Colorado, Colorado

Lynn Romeo, Monmouth University, New Jersey

Gail P. Silkebakken, East Central University, Oklahoma

Adrienne Andi Sosin, Pace University, New York

Gail Keating, Ex Officio, International Reading Association, Delaware

Cathy Roller, Ex Officio, International Reading Association, Delaware

\section{Introduction}

Standards for Reading Professionals_-Revised 2003 [Standards 2003] provides criteria for developing and evaluating preparation programs for reading professionals. These standards answer the question, What should new reading professionals know and be able to do? The focus is on candidate performance and emphasizes the knowledge and skills of candidates as they complete their preparation programs. (These standards do not describe seasoned professionals who would be expected to demonstrate even higher performance levels.) Standards 2003, a revision of Standards for Reading Professionals-Revised 1998 [Standards 1998], summarizes a deliberative process that drew from professional expertise and research in reading and reading instruction.

\section{How are the Standards 2003 changed from Standards 1998?}

The most important change from the Standards 1998 is the increased focus on candidate performance. The criteria included in this document are performance based. This change is a response to shifts in the field of education toward a focus on the outcomes of learning rather than inputs.

The second change is related to format. There are five standards:

1. Foundational Knowledgel

2. Instructional Strategies and Curriculum Materials

3. Assessment, Diagnosis, and Evaluation

4. Creating a Literate Environment, and

5. Professional Development 
Each standard includes several elements. The standard is articulated in a single sentence followed by the stem As a result, candidates:" The stem is followed by a table that lists the elements of the standard down the rows and the reading professionals across the columns. The table replaces the competency matrix of previous versions of the Standards. The word candidate is included in these category labels - Paraprofessional Candidate, Classroom Teacher Candidate, Reading Specialist/Literacy Coach Candidate, Teacher Educator Candidate, and Administrator Candidate - to emphasize that we are describing performance at the end of a preparation program and not the higher performance expectations of a seasoned professional. The elements specify particular knowledge and skills relevant to the standard. Within each cell of the table the criteria for the performance of that element of the standard are stated for that reading professional. The criteria for each professional category are specific and measurable.

The criteria for Paraprofessional and Administrator Candidates are independent of other candidates. The Classroom Teacher must meet the criteria for Paraprofessional as well as those listed under the Classroom Teacher. The Reading Specialist/Literacy Coach candidate must meet the criteria for Paraprofessional and Classroom Teacher as well as those listed under Reading Specialist/Literacy Coach, and the Teacher Educator must meet the criteria for Paraprofessional, Classroom Teacher, and the Reading Specialist/Literacy Coach as well as those listed under Teacher Educator.

From the previous description, the third change in Standards 2003 is evident: There are standards for only five reading professional categories (referred to as roles" in Standards 1998). A fourth change is the inclusion of a table that provides references to research related to each element of each standard. This change is in response to the increasingly ubiquitous call for the use of research-based practices in schools. The included references are to research syntheses that summarize a large number of individual studies related to particular research questions.

A fifth important change is in response to changing population demographics that have created more culturally and linguistically diverse educational contexts. Throughout this document we will refer to "cultural and linguistic diversity." By this term we mean to emphasize that students' cultures and their linguistic backgrounds are crucial characteristics that can have powerful effects on learning. Preparation programs must pay close attention to those differences and prepare all candidates to teach responsively in ways that capitalize on students' cultural and linguistic backgrounds.

A sixth important change is that Standards 2003 places a much heavier emphasis on the use of technology for teaching children and preparing teachers. The reason for the emphasis is quite evident. The use of technology is growing at exponential rates, and teachers and children need to learn to make good use of the technology available.

Following this introduction there is a section describing the reading professional categories. This section is followed by the standards tables, the evidence tables, the references, and the appendixes. 


\section{Who uses these standards and for what purposes?}

Community college, college and university faculties, and state department staff use Standards 2003 in planning preparation programs for reading paraprofessionals, classroom reading teachers, reading specialists/literacy coaches, reading teacher educators, and administrators. These personnel also use it as the basis for evaluating both candidates and programs. In addition, the National Council for Accreditation of Teacher Education (NCATE) uses the criteria for the reading specialist/literacy coach and teacher educator categories in accreditation decisions. The International Reading Association is the Specialty Professional Association (SPA) that conducts reviews of these two categories of reading professions for NCATE accreditation.

Standards 2003 has drawn from professional expertise and reading research to identify the performance criteria relevant to producing competent reading professionals. In planning preparation programs, the Standards provide a guide to program content and program contexts that will result in the production of candidates who know and are able to do the performances described in the standards tables. Because these standards are performance-based rather than "course-based," they allow preparation programs and states more flexibility to design programs.

The Standards also can be used as a guide to develop candidate and program assessment systems. Assessment systems use a set of assessment tools to determine if candidate or program performance meets standards. It is not necessary to create an assessment for each element of each standard when developing assessment systems. For example, suppose a program wants to determine if a candidate's performance meets standard 1. Figure 1 provides an example of how element 1.1 of the standard can be assessed using a Child Study assignment and data from required state testing. The same Child Study assessment assignment also could be used to provide evidence for other elements. For example, it might be used as evidence for standard element 3.2 as it is in the Figure 1 example. The important points are that an overall assessment system can use a few assessment tools to evaluate all the standards' elements, a separate tool for each element is insufficient and unnecessary, and often more than one assessment can be used to provide evidence of meeting the criteria. Whenever possible, assessment systems should include evidence on positive effects on P-12 student learning. 
FIGURE 1

Sample Matrix for Evidence of Candidate Knowledge and Performance

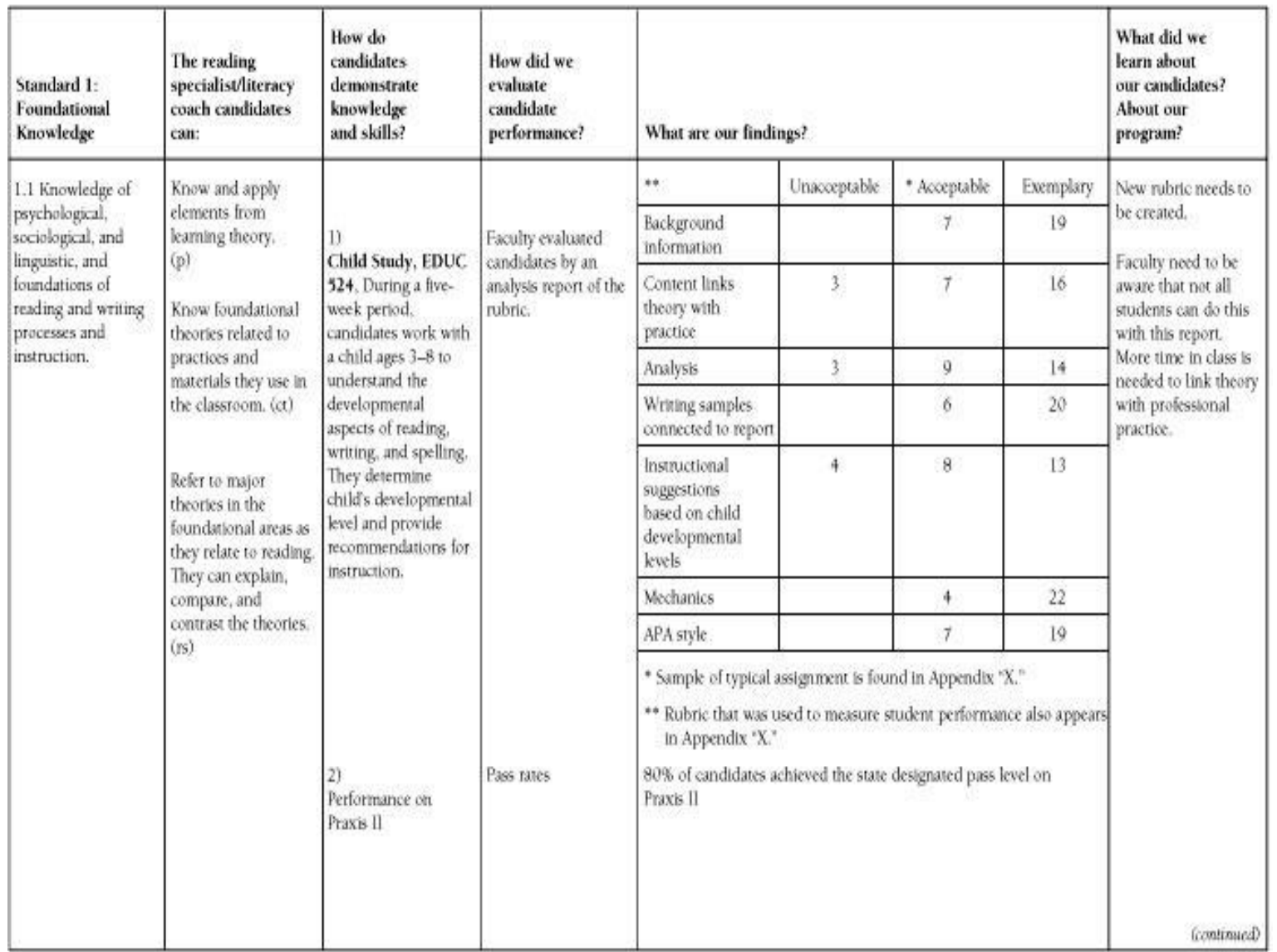

In column two, the Reading Specsalistlineracy Caach candidate must meet the criteria for Paraprolessional ( $\mathrm{p}$ ) and Classroom Teacher (ct) as well as those listed under Reading Spectalistliteracy Coach ( $\mathrm{r}$ ) as designated in the matrix on page 10 . 
FIGURE 1 (continued)

Sample Matrix for Evidence of Candidate Knowledge and Performance

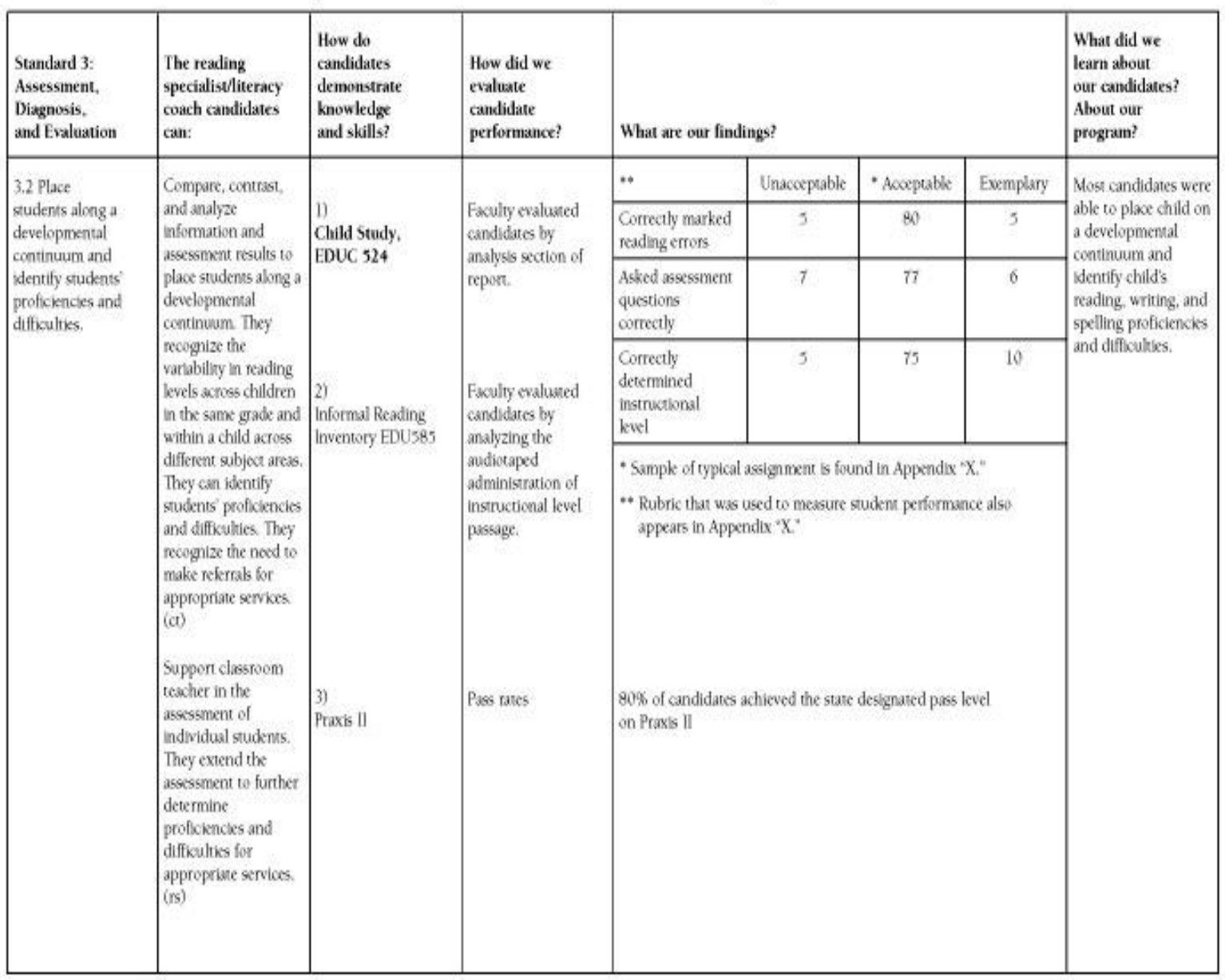

States and accreditation organizations use the Standards for Reading Professionals to determine if preparation programs are adequate for preparing competent reading professionals. NCATE uses the criteria for the reading specialist/literacy coach and teacher education categories to determine if programs are nationally recognized. NCATE also uses these standards to inform their elementary teacher standards related to reading and language arts. These standards have similarly influenced and been influenced by the Interstate New Teacher Assessment and Support Consortium's (INTASC) and the National Board for Professional Teaching Standards' (NBPTS) standards related to reading.

The changes in Standards 2003 are intended to strengthen the field by providing a well-organized and specific set of performance criteria that shape preparation programs. The Standards are the result of a deliberative process that involved the constant intertwining of research evidence and professional judgment. We hope this document will contribute to an evidence-based practice that ultimately improves student reading achievement. 


\section{Part 1 \\ Category Descriptions of Reading Professionals (revised August 2007)}

The International Reading Association recognizes five distinct categories of reading professionals responsible for reading instruction: paraprofessionals, classroom teachers, reading specialists/literacy coaches, teacher educators, and administrators. All have unique roles that reflect differences in responsibilities and in levels and types of students taught. Reading professionals must be prepared appropriately so that when they enter the field they are competent to perform these various roles. Individuals in each of these categories have various degrees of responsibility for supporting and meeting the needs of all students and for interacting with colleagues in a school community to ensure that every student receives appropriate reading instruction.

\section{Category I: The Paraprofessional}

- Assists in regular education, special education, or reading and writing education in graded or age-grouped classrooms at preschool through high-school levels, and in after school and summer programs.

- Has two-year postsecondary degree with an emphasis on human development and educational processes and, for those paraprofessionals who provide reading instruction, 12 semester credit hours, or the equivalent, in literacy and language development.

\section{Category II: The Classroom Teacher}

- Teaches at the early childhood, elementary, middle, or high school level. This category also includes adult continuing education.

- Develops children's reading and related language arts; includes content area teachers who integrate literacy instruction with subject learning.

- Has undergraduate or graduate degree that includes a minimum of 12 hours for preK-grade 5 and a minimum of 6 hours for grades 6-12 teachers of coursework in reading and reading instruction.

\section{Category III: The Reading Specialist}

- Works at the early childhood, elementary, middle, secondary, and/or or adult levels.

- Fulfills a number of responsibilities and many have a specific focus that further defines their duties. For example, a reading specialist can serve as a teacher for students experiencing reading difficulties; as a literacy or reading coach; or as a supervisor or coordinator of reading/literacy. The reading specialist must be prepared to fulfill the duties of all three of these:

- A reading intervention teacher is a reading specialist who provides intensive instruction to struggling readers. Such instruction may be provided either within or outside the students 
classrooms.

- A reading coach or a literacy coach is a reading specialist who focuses on providing professional development for teachers by providing them with the additional support needed to implement various instructional programs and practices. They provide essential leadership for the school?s entire literacy program by helping create and supervise a long-term staff development process that supports both the development and implementation of the literacy program over months and years. These individuals need to have experiences that enable them to provide effective professional development for the teachers in their schools.

- A reading supervisor or reading coordinator is a reading specialist who is responsible for developing, leading, and evaluating a school reading program, from kindergarten through grade 12. They may assume some of the same responsibilities as the literacy coach, but in addition have responsibilities that require them to work more with systematic change at the school level. These individuals need to have experiences that enable them to work effectively as an administrator and to be able to develop and lead effective professional development programs.

- May also include these additional responsibilities:

-Serves as a resource in the area of reading for paraprofessionals, teachers, administrators, and the community.

- Works cooperatively and collaboratively with other professionals in planning programs to meet the needs of diverse populations of learners.

- Provides professional development opportunities at the local and state levels.

- Provides leadership in student advocacy.

- It is expected that the reading specialist will meet the following qualifications:

- Previous teaching experience

- Master's degree with concentration in reading education:

- A minimum of 24 graduate semester hours in reading and language arts and related courses

- An additional 6-semester hours of supervised practicum experience.

\section{Category IV: The Teacher Educator}

- Provides instruction to candidates at the graduate and undergraduate levels.

- Participates in scholarly work, including researching, writing, and professional development. 
- Forges university-school partnerships with other educational agencies to promote the advancement of literacy.

- Has a minimum of three years ${ }^{`}$ teaching experience including the teaching of reading.

- Has a terminal degree that focuses on reading and reading instruction.

\section{Category V: The Administrator}

- Includes principals, superintendents.

- Recognizes and supports reading professionals as they plan, implement, and evaluate effective reading instruction.

- Principals (K-12) have a minimum of 6 credits hours in reading and related language arts.

\section{Part 2}

\section{Standards and Criteria for Judging Performance}

As newly graduated reading professionals enter the field, they must demonstrate the performances essential for meeting the reading instructional needs of all students. In essence, they must give evidence of meeting the standards presented in this document. The five standards are:

1. Candidates have knowledge of the foundations of reading and writing processes and instruction.

2. Candidates use a wide range of instructional practices, approaches, methods, and curriculum materials to support reading and writing instruction.

3. Candidates use a variety of assessment tools and practices to plan and evaluate effective reading instruction.

4. Candidates create a literate environment that fosters reading and writing by integrating foundational knowledge, use of instructional practices, approaches and methods, curriculum materials, and the appropriate use of assessments.

5. Candidates view professional development as a career-long effort and responsibility.

For each of these standards, the matrix that follows describes performance criteria for judging whether preparation programs produce candidates who are competent to meet the instructional needs of their students. Each of the standards has three or four elements that make up the standard. Within the matrix, the performance criteria for each category of professional are listed for each element of the standard. As noted before, with the exception of administrators, the criteria are cumulative. The criteria for administrators are independent of the previous categories because administrators" responsibilities are primarily to provide leadership, supervision, and 
support for reading professionals, and thus require an independent set of performances and criteria.

The five standards can be visualized as a tetrahedron (see Figure 2) with the reading professional at the apex and professional development as the base. The three faces of the tetrahedron are foundational knowledge, use of instructional practices and materials, and use of assessment tools. These three combine to create a literate environment that fosters reading and writing. The tetrahedron rests solidly on the base of professional development that begins with excellent initial preparation and continues with a commitment to lifelong career learning.

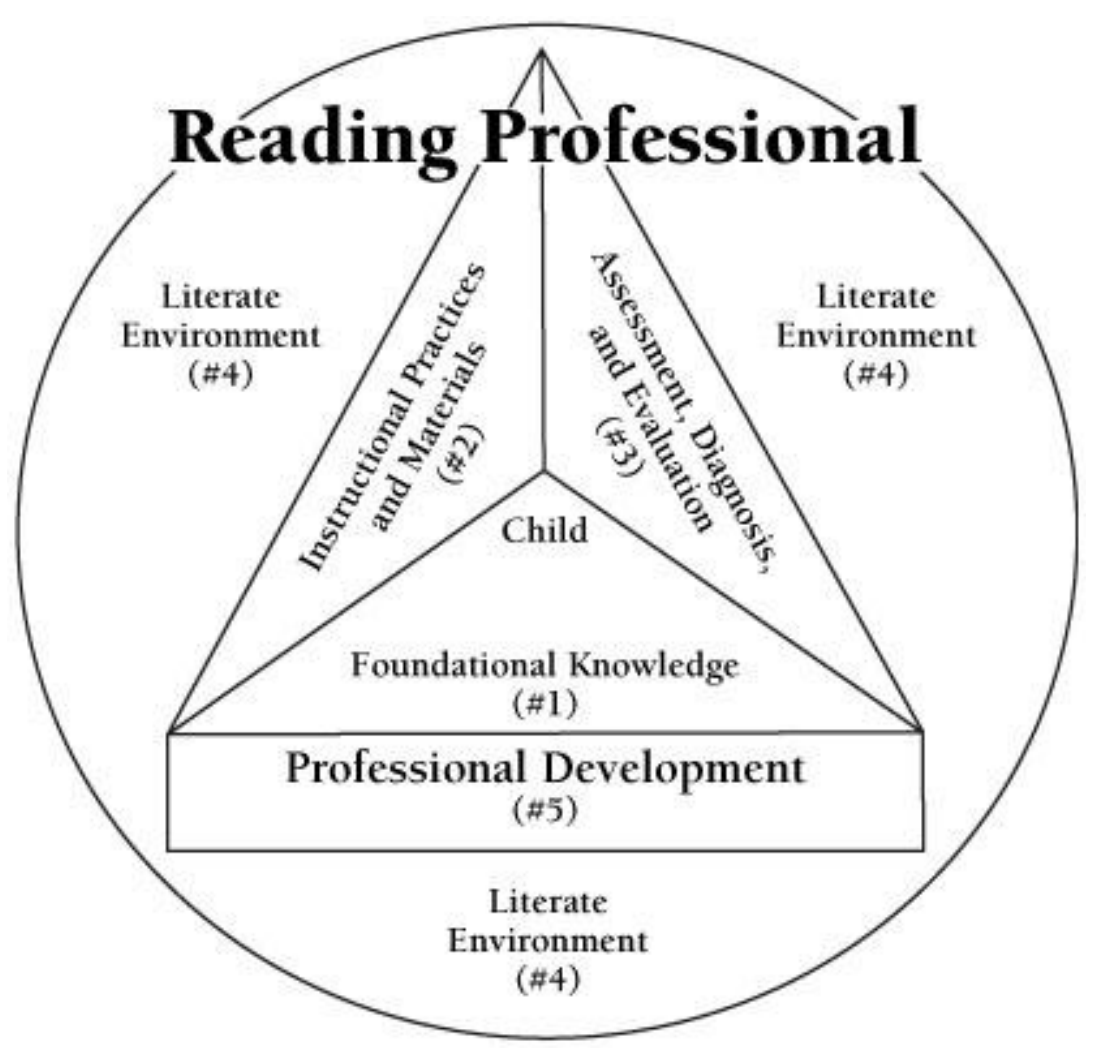


STANDARD 1: FOUNDATIONAL KNOWLEDGE

Candidates have knowledge of the foundations of reading and writing processes and instruction. As a result, candidates:

\begin{tabular}{|c|c|c|c|c|c|}
\hline Element & $\begin{array}{l}\text { Paraprofessional } \\
\text { Candidates }\end{array}$ & $\begin{array}{l}\text { Classroom Teacher } \\
\text { Candidates } \\
\text { (plus previous level) }\end{array}$ & $\begin{array}{l}\text { Reading Specialist' } \\
\text { Literacy Coach Candidates } \\
\text { (plus previous } 2 \text { levels) }\end{array}$ & $\begin{array}{l}\text { Teasher Fiducator } \\
\text { Candidates } \\
\text { (plus previous } 3 \text { levels) }\end{array}$ & $\begin{array}{l}\text { Administrator } \\
\text { Candidates }\end{array}$ \\
\hline $\begin{array}{l}\text { 1.1 Demonstrate knowledge } \\
\text { of prychologeal, sociological. } \\
\text { and linguigic foundations of } \\
\text { reading and wrining processes } \\
\text { and instruction. }\end{array}$ & $\begin{array}{l}\text { Know and apply elements } \\
\text { from kaming theory, }\end{array}$ & $\begin{array}{l}\text { Know foundational theortes } \\
\text { related to practices and } \\
\text { materals they use in the } \\
\text { classroom. }\end{array}$ & $\begin{array}{l}\text { Refer to major theorles in the } \\
\text { foundational areas as they } \\
\text { relate to reading. They can } \\
\text { explain, compare, contrast. } \\
\text { and critique the theories. }\end{array}$ & $\begin{array}{l}\text { Know a wide range of } \\
\text { theories and how they relate } \\
\text { to a range of classroom } \\
\text { practices and materials. They } \\
\text { can summarize empirisal } \\
\text { evidence relaned to these } \\
\text { foundational theories, They } \\
\text { conduct and publish research } \\
\text { and contribute to the } \\
\text { development of the } \\
\text { knowledge base. }\end{array}$ & $\begin{array}{l}\text { Know basic karning theory. } \\
\text { They recognize well- } \\
\text { grounded applications of the } \\
\text { foundational knowledge in } \\
\text { the classroom }\end{array}$ \\
\hline $\begin{array}{l}1.2 \text { Demonstrate knowledge } \\
\text { of reading rexarch and } \\
\text { histories of reading. }\end{array}$ & N/A & $\begin{array}{l}\text { Recognize historical } \\
\text { antecedents to contempotary } \\
\text { reading methods and } \\
\text { mnerisk. They articulate how } \\
\text { their teaching practioes relate } \\
\text { to reading researct. }\end{array}$ & $\begin{array}{l}\text { Summartize seminsl reading } \\
\text { studies and articulste how } \\
\text { these studies impacted } \\
\text { reading instruction. They can } \\
\text { reovunt historkal } \\
\text { developments in the hishory } \\
\text { of resding. }\end{array}$ & $\begin{array}{l}\text { Articulate specific knowledge } \\
\text { bases in their particular area } \\
\text { of research and study. }\end{array}$ & $\begin{array}{l}\text { Know general pattems in the } \\
\text { history of reading, resding } \\
\text { rescarch, methods, and } \\
\text { materals. }\end{array}$ \\
\hline $\begin{array}{l}\text { 1.3 Demonstrate knowledge } \\
\text { of language development and } \\
\text { reading acquisition and the } \\
\text { variations related to cultural } \\
\text { and linguistic diversiry. }\end{array}$ & $\begin{array}{l}\text { Can articulate developmental } \\
\text { aspects of oral language and } \\
\text { its relationship to reading and } \\
\text { writing They can also } \\
\text { summarize the developmental } \\
\text { progression of reading } \\
\text { acquistion and the varlations } \\
\text { related to cultural and } \\
\text { linguistic diversity. }\end{array}$ & $\begin{array}{l}\text { Can describe when students } \\
\text { are moeting derelopmental } \\
\text { benchmarks, They know } \\
\text { when to consult other } \\
\text { professlonak for guidance. }\end{array}$ & $\begin{array}{l}\text { Identify, explain, compare, } \\
\text { and contrast the theories and } \\
\text { research in the areas of } \\
\text { language development and } \\
\text { kaming to read. }\end{array}$ & $\begin{array}{l}\text { Synthesize information across } \\
\text { the knowkdge of leaming } \\
\text { theorics and teaching. They } \\
\text { can explain the connection } \\
\text { between theories and } \\
\text { practices. }\end{array}$ & $\begin{array}{l}\text { Articulate dewelopmental } \\
\text { aspects of oral language and } \\
\text { its relationship to reading and } \\
\text { writing They can also } \\
\text { summarize the developenental } \\
\text { progression of reading }\end{array}$ \\
\hline
\end{tabular}

\begin{tabular}{|c|c|c|c|c|c|}
\hline Element & $\begin{array}{c}\text { Piraprofessional } \\
\text { Candidates }\end{array}$ & $\begin{array}{l}\text { Classroom Teacher } \\
\text { Candidates } \\
\text { (plus previous level) }\end{array}$ & $\begin{array}{c}\text { Reading Specialist/ } \\
\text { Literacy Coach Candidates } \\
\text { (plus previous } 2 \text { levels) }\end{array}$ & $\begin{array}{l}\text { Teacher Educator } \\
\text { Candidates } \\
\text { (plus previous } 3 \text { levels) }\end{array}$ & $\begin{array}{l}\text { Adninistrator } \\
\text { Candidates }\end{array}$ \\
\hline $\begin{array}{l}\text { 1.4 Demonstrate knowledge } \\
\text { of the major components of } \\
\text { reading (phonemic } \\
\text { awareness, word } \\
\text { identification and phonics, } \\
\text { wocabulary and background } \\
\text { knowledge, fluency. } \\
\text { comprehiension strategies, } \\
\text { and motivation) and how } \\
\text { they are integrated in fluent } \\
\text { reading. }\end{array}$ & $\begin{array}{l}\text { List and define the major } \\
\text { components of reading } \\
\text { (phonemic awarencss, word } \\
\text { identification and phonics, } \\
\text { vocabulary and background } \\
\text { knowledge, fluency, } \\
\text { comprehension straneges, } \\
\text { and motivation). }\end{array}$ & $\begin{array}{l}\text { Explain how the components } \\
\text { (phonemik awareness, word } \\
\text { identification and phonics, } \\
\text { vocabulary and background } \\
\text { knowledge, fluency; } \\
\text { comprehension strategies, } \\
\text { and motivation) are } \\
\text { integrated during fluent } \\
\text { reading. They can articulate } \\
\text { the research that grounds } \\
\text { their practice. They identify } \\
\text { student's strengths and } \\
\text { weaknesses in relaron to the } \\
\text { varlous components. }\end{array}$ & $\begin{array}{l}\text { Are able to determine if } \\
\text { students are appropriately } \\
\text { integraring the components } \\
\text { (phenemic awarensss, word } \\
\text { identification and phoniss, } \\
\text { vocabulary and bakkground } \\
\text { knowledge, fluency. } \\
\text { comprehension straseges, } \\
\text { and motivation) in fluknt } \\
\text { reading. }\end{array}$ & $\begin{array}{l}\text { Articulate and synthesize } \\
\text { information about the major } \\
\text { components (phonemic } \\
\text { awareness, word } \\
\text { identification and phonics. } \\
\text { vocabulary and background } \\
\text { knowledge, fluency. } \\
\text { comprehension strateges, } \\
\text { and motivation) and explicate } \\
\text { how the components are } \\
\text { related to instructional } \\
\text { practices and materials. }\end{array}$ & $\begin{array}{l}\text { Explain how the components } \\
\text { (phonemic awarencss, word } \\
\text { identlfication and phonics, } \\
\text { vocabulary and background } \\
\text { knowledge, fluency, } \\
\text { comprehension straseges, } \\
\text { and motivation) are } \\
\text { integrated during fluent } \\
\text { reading. They can articulate } \\
\text { the research that grounds } \\
\text { their practice. }\end{array}$ \\
\hline
\end{tabular}


STANDARD 2; INSTRUCTIONAL STRATEGIES AND CURRICULUM MATERIALS

Candidates use a wide range of instructional practices, approaches, methods, and curriculum materials

to support reading and writing instruction. As a result, candidates:

\begin{tabular}{|c|c|c|c|c|c|}
\hline Element & $\begin{array}{l}\text { Paraprofessional } \\
\text { Candidates }\end{array}$ & $\begin{array}{l}\text { Classroom Teacher } \\
\text { Candidates } \\
\text { (plas previous level) }\end{array}$ & $\begin{array}{c}\text { Reading Specialist } \\
\text { Literacy Coach Candilates } \\
\text { (plus previous } 2 \text { levels) }\end{array}$ & $\begin{array}{l}\text { Teasher Educator } \\
\text { Candidates } \\
\text { (plus previous } 3 \text { levels) }\end{array}$ & $\begin{array}{l}\text { Administrator } \\
\text { Candidates }\end{array}$ \\
\hline $\begin{array}{l}2.11 \text { ke instructional } \\
\text { grouping options (individual, } \\
\text { small-group, whok-dass, } \\
\text { and conputer based) as } \\
\text { appropriate for accomplisbing } \\
\text { given purposes. }\end{array}$ & $\begin{array}{l}\text { lke a varikty of instructional } \\
\text { grouping options selected by } \\
\text { and superved by a } \\
\text { classroum teacher or reading } \\
\text { spectalist. }\end{array}$ & $\begin{array}{l}\text { Match instructional grouping } \\
\text { options to specific } \\
\text { instructional puposes that } \\
\text { take into account } \\
\text { developmental, cultural, and } \\
\text { linguistic differences among } \\
\text { students. They model and } \\
\text { scaffold procedures so that } \\
\text { students leam to work } \\
\text { effectively. They provide an } \\
\text { evidence-based rationale for } \\
\text { their selections. }\end{array}$ & $\begin{array}{l}\text { Support classroom texchers } \\
\text { and paraprofessionals in their } \\
\text { use of instructional grouping } \\
\text { options. They help teachers } \\
\text { select appropriate options. } \\
\text { They demonstrate the options } \\
\text { and explain the evidence- } \\
\text { based rationale for changing } \\
\text { configurations to best meer } \\
\text { the needs of all sudents. }\end{array}$ & $\begin{array}{l}\text { Prepare and coach preservice } \\
\text { candidates and inservice } \\
\text { teachers to use instuctional } \\
\text { grouping options. They } \\
\text { provide the candidates with } \\
\text { opportunities to select, use, } \\
\text { and practioe the options. }\end{array}$ & $\begin{array}{l}\text { Evaluate, support, and couch } \\
\text { teachers' use of instructional } \\
\text { grouping options for specific } \\
\text { purposes based on their } \\
\text { appropriateness for those } \\
\text { purposes and for } \\
\text { accommodating cultural and } \\
\text { linguistic differences among } \\
\text { their students. }\end{array}$ \\
\hline
\end{tabular}

\begin{tabular}{|c|c|c|c|c|c|}
\hline Element & $\begin{array}{l}\text { Paraprofessional } \\
\text { Candidates }\end{array}$ & $\begin{array}{l}\text { Classroom Teacher } \\
\text { Candidates } \\
\text { (plus previous level) }\end{array}$ & $\begin{array}{l}\text { Reading Specialist } \\
\text { Literacy Coach Candidates } \\
\text { (plus previous } 2 \text { levels) }\end{array}$ & $\begin{array}{l}\text { Teasher Fducator } \\
\text { Candidates } \\
\text { (plus previous } 3 \text { levels) }\end{array}$ & $\begin{array}{l}\text { Administrator } \\
\text { Candidates }\end{array}$ \\
\hline $\begin{array}{l}2.3 \text { Use a wide range of } \\
\text { currikulum materials in } \\
\text { effective reading instruktion } \\
\text { for leamers an different sages } \\
\text { of reading and writing } \\
\text { development and from } \\
\text { different cultural and } \\
\text { lingulstic backgrounds. }\end{array}$ & $\begin{array}{l}\text { Use a widk range of } \\
\text { currikulum materials selected } \\
\text { by a classroom teacher of } \\
\text { reading specialst. }\end{array}$ & $\begin{array}{l}\text { Plan for the use of a wide } \\
\text { range of curriculum maserials. } \\
\text { Their selkations are guided by } \\
\text { an evidence-biced rationale } \\
\text { and accommodate the } \\
\text { developmental, cultural, and } \\
\text { linguistc differences of their } \\
\text { students. }\end{array}$ & $\begin{array}{l}\text { Support classroom teachers } \\
\text { and paraprefessionals in the } \\
\text { use of a wide range of } \\
\text { cumikulum materials. They } \\
\text { help teachers stket } \\
\text { appropriate options and } \\
\text { explain the evidence base for } \\
\text { selecting practioes to best } \\
\text { moet the needs of all } \\
\text { students. They demonstrate } \\
\text { the optors in their own } \\
\text { teaching and in } \\
\text { demonstration teaching }\end{array}$ & 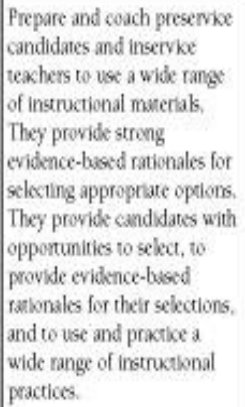 & $\begin{array}{l}\text { Evaluate. support, and coach } \\
\text { weakhers use of a wide range } \\
\text { of curriculum manerlals for } \\
\text { specific purposes based on } \\
\text { their appropriateness for } \\
\text { those purposes and for } \\
\text { accommodating } \\
\text { developmental, cultural, and } \\
\text { linguistic differenoes among } \\
\text { their students. They ensure } \\
\text { that teachers' selections are } \\
\text { supported by an evidenoc- } \\
\text { based rationak. }\end{array}$ \\
\hline
\end{tabular}


STANDARD 3: ASSESSMENT, DIAGNOSIS, AND EVALUATION

Candidates use a variety of assessment tools and practices to plan and evaluate effective reading instruction. As a result, candidates:

\begin{tabular}{|c|c|c|c|c|c|}
\hline Element & $\begin{array}{c}\text { Paraprofessional } \\
\text { Candidates }\end{array}$ & $\begin{array}{l}\text { Classroom Teacher } \\
\text { Candidates } \\
\text { (plus previous level) }\end{array}$ & $\begin{array}{l}\text { Reading Specialist' } \\
\text { Literacy Coach Candidates } \\
\text { (plus previous } 2 \text { levels) }\end{array}$ & $\begin{array}{c}\text { Teasher Educator } \\
\text { Candidates } \\
\text { (plus previous } 3 \text { levels) }\end{array}$ & $\begin{array}{l}\text { Administrator } \\
\text { Canclidates }\end{array}$ \\
\hline $\begin{array}{l}\text { 3.1 l ke a wide range of } \\
\text { assessment tools and practices } \\
\text { that range from individual } \\
\text { and group gandardized tests } \\
\text { to individual and group } \\
\text { informal classroom } \\
\text { assessment grategies, } \\
\text { including tectunology-bused } \\
\text { aseesment tools. }\end{array}$ & $\begin{array}{l}\text { Administer scriped formal } \\
\text { and informal asessments and } \\
\text { technology-based assessments } \\
\text { under the direction of } \\
\text { certified personnel. }\end{array}$ & $\begin{array}{l}\text { selost and administer } \\
\text { appropriate formal and } \\
\text { informal assessments } \\
\text { including technology-based } \\
\text { assessments. They understand } \\
\text { the requirements for technical } \\
\text { adequacy of assessments and } \\
\text { can selest technically } \\
\text { adequate assessment took. } \\
\text { They can interpret the results } \\
\text { of these tests and } \\
\text { assessments. }\end{array}$ & $\begin{array}{l}\text { Compare and contrast, use, } \\
\text { interpret, and recommend a } \\
\text { wide range of assessnent } \\
\text { tools and practices. } \\
\text { Ascessments may range from } \\
\text { standardized tests to informal } \\
\text { assessments and also incluck } \\
\text { technology-based } \\
\text { assessments. They } \\
\text { demonstrate appropriate use } \\
\text { of assessments in their } \\
\text { practice, and they can train } \\
\text { classroom teachers to } \\
\text { administer and interpret these } \\
\text { assessments. }\end{array}$ & $\begin{array}{l}\text { Prepare and coach preservice } \\
\text { candidates and inservice } \\
\text { teachers to administer and } \\
\text { interpret assessments } \\
\text { appropriate for elected } \\
\text { purposes. They interpret and } \\
\text { critique technical aspects of } \\
\text { assessments. They can } \\
\text { anticulate ahat makes up an } \\
\text { effective asessment plan. }\end{array}$ & $\begin{array}{l}\text { 1nderstand the rok of } \\
\text { assessment in the delivery of } \\
\text { excellent reading instruction. } \\
\text { Working with reading } \\
\text { professtionak, they can } \\
\text { develop approprate building } \\
\text { and dstrictwide ascessment } \\
\text { plans. }\end{array}$ \\
\hline $\begin{array}{l}\text { 3.2 Place students along a } \\
\text { developmental continumum } \\
\text { and lidentify studknts } \\
\text { proficiencies and diffoultixs. }\end{array}$ & $\mathrm{NA}$ & 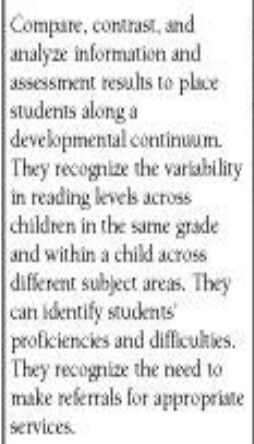 & $\begin{array}{l}\text { Support the classroom } \\
\text { teacher in the assessenent of } \\
\text { individual students. They } \\
\text { extend the dssessment to } \\
\text { further determine } \\
\text { proficiencies and diffculies } \\
\text { for approprate servioes. }\end{array}$ & $\begin{array}{l}\text { Prepare and coach preservice } \\
\text { candidates and inservice } \\
\text { teachers to plicx students } \\
\text { along a developmental } \\
\text { continuum. They ground this } \\
\text { preparation in research. }\end{array}$ & $\begin{array}{l}\text { Know the range of students } \\
\text { reading performance in the ir } \\
\text { building or under their } \\
\text { oontrol and know how this } \\
\text { range relates to the brouder } \\
\text { student population. They } \\
\text { provide support for an } \\
\text { effective asocsoment plan. }\end{array}$ \\
\hline
\end{tabular}




\begin{tabular}{|c|c|c|c|c|c|}
\hline Element & $\begin{array}{l}\text { Paraprofessional } \\
\text { Candidates }\end{array}$ & $\begin{array}{l}\text { Classrooun Teacher } \\
\text { Candidates } \\
\text { (plus previous level) }\end{array}$ & $\begin{array}{c}\text { Reading Specialist } \\
\text { Literacy Coach Candidates } \\
\text { (plus previous } 2 \text { levels) }\end{array}$ & $\begin{array}{l}\text { Teasher Educator } \\
\text { Candidates } \\
\text { (plus previous } 3 \text { levels) }\end{array}$ & $\begin{array}{l}\text { Administrator } \\
\text { Candiduates }\end{array}$ \\
\hline $\begin{array}{l}3.3 \text { lse assessment } \\
\text { information to plan, evaluate, } \\
\text { and revise effective } \\
\text { instruktion that meets the } \\
\text { needs of all students, } \\
\text { including those at different } \\
\text { developmental stages and } \\
\text { those from different cultural } \\
\text { and linguistic backgrounds. }\end{array}$ & $\mathrm{N} / \mathrm{A}$ & $\begin{array}{l}\text { Analyze, compare, contrast. } \\
\text { and use assessmknt resulls to } \\
\text { plan, cvaluate, and revise } \\
\text { effective instruction for all } \\
\text { students within an } \\
\text { assessment/evaluation' } \\
\text { instruknon cycle. }\end{array}$ & $\begin{array}{l}\text { Assist the classroom teacher } \\
\text { in using assessment to plan } \\
\text { instruction for all students. } \\
\text { They use in-depth assessment } \\
\text { information to plan } \\
\text { individual instruction for } \\
\text { struggling readers. They } \\
\text { collaborate with other } \\
\text { education professionals to } \\
\text { implement appropriate } \\
\text { reading instruction for } \\
\text { individual students. They } \\
\text { collect, analyze, and use } \\
\text { schoolwide assessment data } \\
\text { to implement and revise } \\
\text { school reading programs. }\end{array}$ & 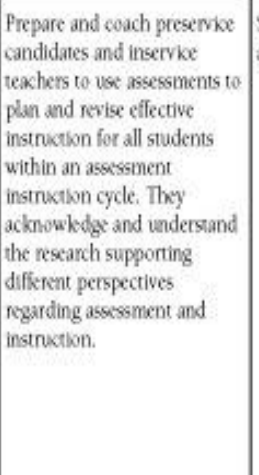 & $\begin{array}{l}\text { Support professional uses of } \\
\text { assessment data. }\end{array}$ \\
\hline $\begin{array}{l}3.4 \text { Communicate results of } \\
\text { assessments to specific } \\
\text { individuals (students, } \\
\text { parents, caregivers, } \\
\text { colkagues, administratoss, } \\
\text { polkymakers, policy officias, } \\
\text { community, ecc.). }\end{array}$ & $\mathrm{N} / \mathrm{A}$ & $\begin{array}{l}\text { Interpret a student's reading } \\
\text { profile from asessments and } \\
\text { communicale the results to } \\
\text { the studkn, parents, } \\
\text { caregivers, colkagues, and } \\
\text { administrators. }\end{array}$ & 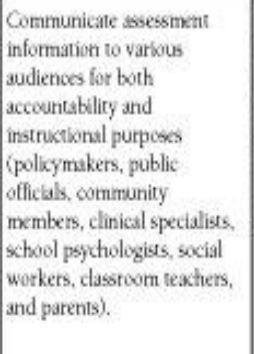 & 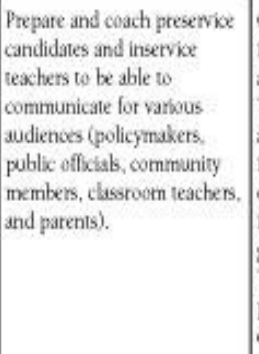 & 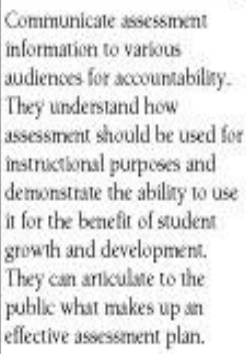 \\
\hline
\end{tabular}




\section{STANDARD 4: CREATING A LITERATE ENVIRONMENT}

Candidates create a literate environment that fosters reading and writing by integrating foundational knowledge, use of instructional practices, approaches and methods, curriculum materials, and the appropriate use of assessments. As a result, candidates:

\begin{tabular}{|c|c|c|c|c|c|}
\hline Element & $\begin{array}{l}\text { Paraprofessional } \\
\text { Candidates }\end{array}$ & $\begin{array}{l}\text { Classroom Teacher } \\
\text { Candidates } \\
\text { (plas previous level) }\end{array}$ & $\begin{array}{l}\text { Reading Specialist } \\
\text { Literacy Coach Candinbates } \\
\text { (plus previous } 2 \text { levels) }\end{array}$ & $\begin{array}{c}\text { Teacher Educator } \\
\text { Candidates } \\
\text { (plus previous } 3 \text { levels) }\end{array}$ & $\begin{array}{l}\text { Administrator } \\
\text { Candidates }\end{array}$ \\
\hline $\begin{array}{l}\text { 4.1 lke students interess; } \\
\text { reading abxlities, and } \\
\text { backgrounds as foundarions } \\
\text { for the reading and wrting } \\
\text { program }\end{array}$ & $\begin{array}{l}\text { Assist the reacher and reading } \\
\text { spectalis in gathering } \\
\text { information on suderas } \\
\text { interess and culkural and } \\
\text { linguistic backgrounds. They } \\
\text { can use appropriate } \\
\text { technology to collect this } \\
\text { information. }\end{array}$ & 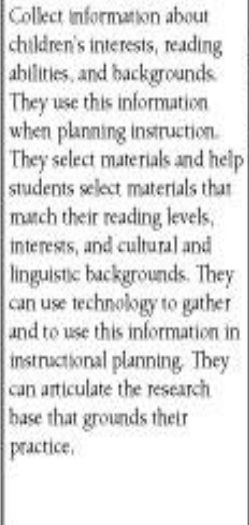 & $\begin{array}{l}\text { Assist the classroom reacher } \\
\text { and paraprofessional in } \\
\text { selecting materials that match } \\
\text { the reading kevels, interests. } \\
\text { and cultural and linguistic } \\
\text { background of students. }\end{array}$ & $\begin{array}{l}\text { Prepare and coach preservice } \\
\text { candidates and inservice } \\
\text { teachers in gathering } \\
\text { information rekvant to } \\
\text { creating a literate } \\
\text { enviroument. They } \\
\text { demonstrate how to level } \\
\text { materuak, assess the cultural } \\
\text { and linguistical } \\
\text { appropriateness and match } \\
\text { maseruls to student interest. } \\
\text { They demonstate the } \\
\text { development of instructional } \\
\text { plans based on students } \\
\text { interests and caltural and } \\
\text { linguistc backgrounds. They } \\
\text { can use technology to } \\
\text { enhance these processes. }\end{array}$ & $\begin{array}{l}\text { Support the professional graff } \\
\text { in designing curriculum } \\
\text { based on students' interests, } \\
\text { reading abylities, and cultural } \\
\text { and linguistic backgrounds } \\
\text { They can articulate the } \\
\text { research that grounds their } \\
\text { practice. }\end{array}$ \\
\hline $\begin{array}{l}42 \text { lase a large supply of } \\
\text { books, technology-hased } \\
\text { information, and nonprint } \\
\text { materuls representing } \\
\text { multiple kevels, broad } \\
\text { interests, and cultural and } \\
\text { linguistic backgrourds. }\end{array}$ & $\begin{array}{l}\text { Assist studerns in selecting } \\
\text { books, technolog-based } \\
\text { information, and nooprint } \\
\text { materals that are appropriate } \\
\text { for them. }\end{array}$ & $\begin{array}{l}\text { Select books, technology- } \\
\text { based information. and } \\
\text { nonprint materiak } \\
\text { representing multiple levek, } \\
\text { broad interests, and cultural } \\
\text { and linguistic backgrounds. } \\
\text { They can articulate the } \\
\text { restarch that grounds their } \\
\text { practice. }\end{array}$ & $\begin{array}{l}\text { Assist the classroom teacher } \\
\text { in selecting books, } \\
\text { rechnology-hased } \\
\text { information, and nonprint } \\
\text { materials representing } \\
\text { multiple kevels, broad } \\
\text { interesss, and cultural and } \\
\text { linguistic backgrounds. }\end{array}$ & $\begin{array}{l}\text { Prepare and coach preservike } \\
\text { candidates and inservike } \\
\text { teachers in the sekction of } \\
\text { books, technology-based } \\
\text { information, and nonprint } \\
\text { materuls representing } \\
\text { multiple kevels, broad } \\
\text { interests, and cultural and } \\
\text { linguistic backgrounds. }\end{array}$ & $\begin{array}{l}\text { Support the professional saff } \\
\text { in selecting books. } \\
\text { technology-lused } \\
\text { information. and nonprint } \\
\text { maneruls representing } \\
\text { multiple kvek, broad } \\
\text { interests, and cultural and } \\
\text { linguistic backgrounds. They } \\
\text { can articulate the research } \\
\text { that grounds their prastice. }\end{array}$ \\
\hline
\end{tabular}




\begin{tabular}{|c|c|c|c|c|c|}
\hline Element & $\begin{array}{l}\text { Paraprofessional } \\
\text { Candidates }\end{array}$ & $\begin{array}{l}\text { Classroom Teacher } \\
\text { Candidutes } \\
\text { (plus previous level) }\end{array}$ & $\begin{array}{c}\text { Reauding Specialist } \\
\text { Literacy Coach Candiatates } \\
\text { (plus previous } 2 \text { levels) }\end{array}$ & $\begin{array}{l}\text { Teacher Educator } \\
\text { Candidates } \\
\text { (plus previous } 3 \text { levels) }\end{array}$ & $\begin{array}{l}\text { Administrator } \\
\text { Candidates }\end{array}$ \\
\hline $\begin{array}{l}\text { 4.3 Model neading and } \\
\text { writing enthuslastically as } \\
\text { valued liselong aktivitics. }\end{array}$ & $\begin{array}{l}\text { Read aboud enthuskistically } \\
\text { and fluently when reading to } \\
\text { students. }\end{array}$ & $\begin{array}{l}\text { Model and share the use of } \\
\text { reading and writing for real } \\
\text { purposes in daily life. They } \\
\text { use think-alouds to } \\
\text { demonstrate good reading } \\
\text { and writing strasegles. They } \\
\text { can articulate the research } \\
\text { that suppons modeling think- } \\
\text { alouds and read-allowds to } \\
\text { students. }\end{array}$ & $\begin{array}{l}\text { Demonstrate and model } \\
\text { readng and wring for real } \\
\text { purposes in daily interactions } \\
\text { with students and educunon } \\
\text { professlonak. Assist teachers } \\
\text { and paraprofessionals to } \\
\text { model reading and writing as } \\
\text { valued lifilong activitics. }\end{array}$ & $\begin{array}{l}\text { Prepare and coasch preservike } \\
\text { candidates and inservike } \\
\text { teakhers to model and share } \\
\text { the use of reading and writing } \\
\text { for real purposes in daily life. } \\
\text { They demonstrate the prooss } \\
\text { of think-alouds, They model } \\
\text { how to read aloud } \\
\text { enthusiastically and fluently. }\end{array}$ & $\begin{array}{l}\text { Particlpate and support the } \\
\text { professtonal saff in modeling } \\
\text { reading and wrting } \\
\text { enthusiastically as valund } \\
\text { lifiklong activitiks. }\end{array}$ \\
\hline $\begin{array}{l}\text { 4.4 Motivate kamers to be } \\
\text { liselong neaders. }\end{array}$ & $\begin{array}{l}\text { Support students choikes of } \\
\text { readeng materials. }\end{array}$ & 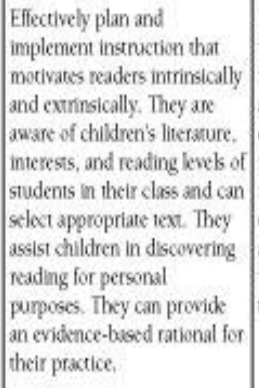 & 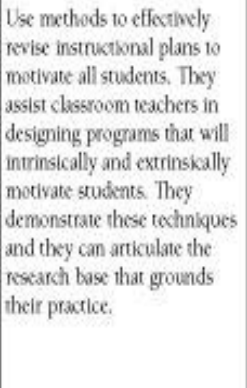 & $\begin{array}{l}\text { Prepare and coach presewike } \\
\text { candidates and inservike } \\
\text { reachers in the use of effoctive } \\
\text { motivational reading } \\
\text { techniques. }\end{array}$ & $\begin{array}{l}\text { Support the profiksional staff } \\
\text { in dssigning intrinsic and } \\
\text { extrinsic motivational } \\
\text { programs. }\end{array}$ \\
\hline
\end{tabular}


STANDARD 5: PROFESSIONAL DEVELOPMENT

Candidates view professional development as a career-long effort and responsibility. As a result, candidates:

\begin{tabular}{|c|c|c|c|c|c|}
\hline Element & $\begin{array}{l}\text { Paraprofessional } \\
\text { Candidates }\end{array}$ & $\begin{array}{l}\text { Classroom Teacher } \\
\text { Candidates } \\
\text { (plus previous level) }\end{array}$ & $\begin{array}{l}\text { Reading Specialist' } \\
\text { Literacy Coach Candidates } \\
\text { (plus previous } 2 \text { levels) }\end{array}$ & $\begin{array}{c}\text { Teasher Fducator } \\
\text { Candidates } \\
\text { (plus previous } 3 \text { levels) }\end{array}$ & $\begin{array}{l}\text { Administrator } \\
\text { Cancladates }\end{array}$ \\
\hline $\begin{array}{l}\text { 5.1 Display positive } \\
\text { dispositions related to reading } \\
\text { and the teaching of reading. }\end{array}$ & $\begin{array}{l}\text { Know the imponance of } \\
\text { confidentialiny, and respert } \\
\text { students and their cultural } \\
\text { and linguisic backgrounds. } \\
\text { They care for the well-being } \\
\text { of students and believe that } \\
\text { all students can learn. }\end{array}$ & $\begin{array}{l}\text { Ensure that all individuals } \\
\text { project ethical and caring } \\
\text { attitudes in the classroom. } \\
\text { They work wath families, } \\
\text { colleagues, and communities } \\
\text { to support students leaming }\end{array}$ & $\begin{array}{l}\text { Articulate the theories related } \\
\text { to the connections between } \\
\text { texher dispositions and } \\
\text { student actievement. }\end{array}$ & $\begin{array}{l}\text { Articulate the reseirch bace } \\
\text { related to the connections } \\
\text { between teacher dispositions } \\
\text { and student achievement. }\end{array}$ & $\begin{array}{l}\text { Ensure that there is an ethical } \\
\text { karning context for reading } \\
\text { instruction that respects } \\
\text { students, families, teachers, } \\
\text { colleagues, and communities. }\end{array}$ \\
\hline $\begin{array}{l}5.2 \text { Continue to pursue the } \\
\text { development of professional } \\
\text { knowledge and dispesitions. }\end{array}$ & $\begin{array}{l}\text { Study specific aspects of } \\
\text { reading/nstruction as } \\
\text { recommended by teachers, } \\
\text { reading specialsis, and/or } \\
\text { principak with whom they } \\
\text { work. They demonstrate a } \\
\text { cunnosity and interest in the } \\
\text { area of knowledge, skilk, and } \\
\text { dispositions related to reading } \\
\text { and writing instruction. }\end{array}$ & 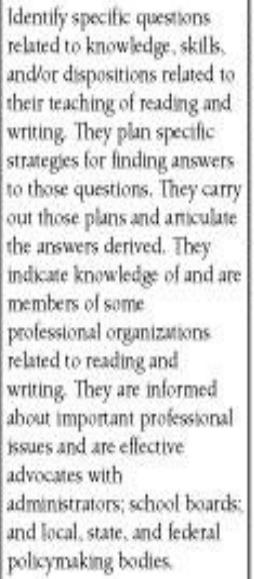 & $\begin{array}{l}\text { Conduct professional study } \\
\text { groups for paraprofescionals } \\
\text { and teachers. Assist classroom } \\
\text { teachers and paraprofessionals } \\
\text { in identifying, planning, and } \\
\text { implementing personal } \\
\text { protessional development } \\
\text { plans. Advocate to advanoe } \\
\text { the professional research base } \\
\text { to expand knowiedge-bused } \\
\text { practices. }\end{array}$ & $\begin{array}{l}\text { Read, compare, and contras } \\
\text { anicles in professional } \\
\text { joumals and other } \\
\text { publications. They regularly } \\
\text { participate in professional } \\
\text { conferenoes. They conduct } \\
\text { research and write for } \\
\text { appropriate purposes. They } \\
\text { prepare and coach preservice } \\
\text { candidates and inservice } \\
\text { teachers to conduat teacher } \\
\text { action research. }\end{array}$ & $\begin{array}{l}\text { Support teachers and reading } \\
\text { spectalists to develop their } \\
\text { professional knowiedge, } \\
\text { skills, and dspositions. They } \\
\text { provide information ahout } \\
\text { opportunities for teachers and } \\
\text { reading specialsts to engage } \\
\text { in professional development. }\end{array}$ \\
\hline
\end{tabular}




\begin{tabular}{|c|c|c|c|c|c|}
\hline Element & $\begin{array}{c}\text { Paraprofessional } \\
\text { Candidates }\end{array}$ & $\begin{array}{l}\text { Classroom Teacber } \\
\text { Candidates } \\
\text { (plus previous level) }\end{array}$ & $\begin{array}{l}\text { Reading Specialist } \\
\text { Literacy Coach Candidates } \\
\text { (plus previous } 2 \text { levels) }\end{array}$ & $\begin{array}{l}\text { Teacher Fiducator } \\
\text { Candidates } \\
\text { (plus previous } 3 \text { levels) }\end{array}$ & $\begin{array}{l}\text { Adninistrator } \\
\text { Candidates }\end{array}$ \\
\hline $\begin{array}{l}5.3 \text { Work with colleaguss to } \\
\text { observe, evaluane. and } \\
\text { provide fordback on each } \\
\text { other's practioe. }\end{array}$ & NA & $\begin{array}{l}\text { Actively engage in } \\
\text { collaboranbo and dialogue } \\
\text { with other teachers and } \\
\text { reading specialsis to obtain } \\
\text { recommendations and advice } \\
\text { on teaching practioes and } \\
\text { ideas. They can articulate the } \\
\text { evidence base relaned to these } \\
\text { reommendanions. They may } \\
\text { conduct action resarch as a } \\
\text { pant of these collaberations. }\end{array}$ & $\begin{array}{l}\text { Positively and constructively } \\
\text { provide an evaluation of their } \\
\text { own of others' teaching } \\
\text { practices. Assist classroom } \\
\text { teakhers and paraprofessionals } \\
\text { as they strive to improve their } \\
\text { practice. }\end{array}$ & $\begin{array}{l}\text { Read related research studies } \\
\text { and use reflection as they } \\
\text { actively engege in dalogue } \\
\text { with oher professionals in } \\
\text { observation, evaluation, and } \\
\text { focdback activitics. }\end{array}$ & $\begin{array}{l}\text { Encourage and faclitiate } \\
\text { collaboranon and dialoge } \\
\text { betwoen professional } \\
\text { personnel. }\end{array}$ \\
\hline $\begin{array}{l}\text { 5.4 Participate in, initiate, } \\
\text { implement, and evaluate } \\
\text { professional development } \\
\text { programs. }\end{array}$ & NA & $\begin{array}{l}\text { Participare individually and } \\
\text { with colleagues in } \\
\text { professional development } \\
\text { experiknces. }\end{array}$ & $\begin{array}{l}\text { Exhibit leadership skills in } \\
\text { professionsl development. } \\
\text { They plan, implement, and } \\
\text { evaluate professional } \\
\text { development efforts at the } \\
\text { grade, school, district, and/or } \\
\text { state level, They are cognizant } \\
\text { of and can identily and } \\
\text { describe the characteristics of } \\
\text { sound professional } \\
\text { development programs. They } \\
\text { can articulate the evidence } \\
\text { base that grounds their } \\
\text { practice. }\end{array}$ & $\begin{array}{l}\text { Prepare and coach the } \\
\text { reading specialist to plan. } \\
\text { implement, and evaluate } \\
\text { professional development } \\
\text { efforts at the grade, school, } \\
\text { dstrict, and state leveL They } \\
\text { alse parricipare in } \\
\text { professional dewelopment } \\
\text { through the national level. }\end{array}$ & $\begin{array}{l}\text { Provide opportunitics for } \\
\text { school saff to antend } \\
\text { professional development } \\
\text { programs. They bring } \\
\text { consultanns to school and } \\
\text { district level for sustaned } \\
\text { professlonal dewelopnent. }\end{array}$ \\
\hline
\end{tabular}

\section{Part 3 Evidence}

The following charts are a summary of the chapters and pages that support each element of the standards from the following books (complete references follow charts): Handbook of Reading Research Volumes I, II, and III (HRR1, HRR2, and HRR3); Preventing Reading Difficulties in Young Children (PRD); Report of the National Reading Panel (NRPR); Theoretical Models and Processes of Reading, Fourth Edition (TMPR4); and What Research Has To Say About Reading Instruction, Third Edition (WRS3) 
STANDARD 1

Foundational Knowledge and Dispositions

\begin{tabular}{|c|c|c|c|c|c|c|c|}
\hline Element & HRRI & HRR2 & HRR3 & PRD & NRPR & TMPR4 & WR53 \\
\hline $\begin{array}{l}\text { 1.1 Demonstrate knowiedge of } \\
\text { poychological, sociological, and linguistic } \\
\text { foundations of reading and writing } \\
\text { procesces and instruction. }\end{array}$ & $9,13,14,16$ & $1,5,21$ & 16,34 & & & $\begin{array}{c}7,8,9,10,11,26 \\
27,28,38,30,42 \\
43,44,46\end{array}$ & 2,3 \\
\hline $\begin{array}{l}\text { 1.2 Demonstrate knowikdge of reading } \\
\text { restarch and histories of reading. }\end{array}$ & $1.2,3,4,18,23$ & 1, 3, Epilogux & $\begin{array}{l}1-5 \\
6-15\end{array}$ & & & 1.2 & 1 \\
\hline $\begin{array}{l}\text { 1.3 Demonstrate knowkedge of languge } \\
\text { development and reading acquisition and } \\
\text { the variakons rebeed to cultural and } \\
\text { linguistic diversity. }\end{array}$ & 17 & $\begin{array}{c}5,19,20,22,26 \\
27\end{array}$ & $\begin{array}{c}25,41,42,43,44 \\
45\end{array}$ & 2 & & $\begin{array}{c}3,5,12,13,14 \\
15,18\end{array}$ & 4. 12,17 \\
\hline $\begin{array}{l}\text { 1.4 Demonstrate knowledge of the major } \\
\text { components of reading (phonemic } \\
\text { awareness, word ideneification and } \\
\text { phonics, wocabulary and background } \\
\text { knowledge, fluency, comprehension } \\
\text { strateges, and motvation) and how they } \\
\text { are integrated in fluent reading. }\end{array}$ & $\begin{array}{c}5,7,8,12,14,19 \\
20,21,25\end{array}$ & \begin{tabular}{|}
$8,9,10,15,16$ \\
$17,18,21,23,24$ \\
$25,26,27,28,20$
\end{tabular} & $\begin{array}{l}16,17,18,19,20 \\
23,24,27,28,30 \\
31,32,33,34,35\end{array}$ & 2 & $2,3,4$ & $\begin{array}{c}13,15,16,17,19 \\
20-29,30-33 \\
34-37,40,41,47\end{array}$ & $\begin{array}{c}3,6,7,8,9,10 \\
13\end{array}$ \\
\hline
\end{tabular}


STANDARD 2:

Instructional Strategies and Curriculum Materials

\begin{tabular}{|c|c|c|c|c|c|c|c|}
\hline Element & HRRI & HRR2 & HRR3 & PRD & NRPR & TMPR4 & WR53 \\
\hline $\begin{array}{l}2.1 \text { lse instructional grouping options } \\
\text { (individual, small-group. whole-class, } \\
\text { and computer based) as appropriate for } \\
\text { accomplishing given purposes. }\end{array}$ & & 31 & & & & & \\
\hline $\begin{array}{l}2.2 \text { Use a ride range of instructional } \\
\text { practices, approaches, and methods, } \\
\text { inchuding tectunology-bused practices, for } \\
\text { kamers at different stages of development } \\
\text { and from differing culrural and lingulstic } \\
\text { backgroundk. }\end{array}$ & $17,18,23,24,25$ & $13,30,32,33,34$ & $\begin{array}{c}21,25,26,29,36 \\
39,40\end{array}$ & $5-8$ & 6 & $6,7,8,14$ & $2,4,9,14$ \\
\hline $\begin{array}{l}2.3 \text { Use a widk range of curriculum } \\
\text { maserials in effective reading instroction for } \\
\text { kamers at different stiges of reading and } \\
\text { writing development and from differing } \\
\text { culcural and linguistic backgrounds. }\end{array}$ & 11,22 & 6 & $22,31,32,33$ & & & 13,14 & \\
\hline
\end{tabular}


STANDARD 3

Assessment, Diagnosis, and Evaluation

\begin{tabular}{|c|c|c|c|c|c|c|c|}
\hline Element & HRR1 & HRR2 & HRR3 & PRD & NRPR & TMPR4 & WR53 \\
\hline $\begin{array}{l}3.1 \text { lse a wide range of assessment tools } \\
\text { and practices that range from indwidual } \\
\text { and group standardized tests to individual } \\
\text { and group informal classroom assessment } \\
\text { strategies, including technology-bised } \\
\text { assessment tools. }\end{array}$ & 6.25 & 12 & & 3,4 & & 6 & 15,16 \\
\hline $\begin{array}{l}\text { 3.2 Place students along a developmental } \\
\text { continuum and identify sudens' } \\
\text { proficienciks and diffoculics. }\end{array}$ & 6.16 & 12 & & 3,4 & & & 15 \\
\hline $\begin{array}{l}\text { 3.3 lke assessment information to plan, } \\
\text { evaluate, and revise effective instruction } \\
\text { that meets the needs of all students, } \\
\text { including those at different developmental } \\
\text { stages and those from differing cultural and } \\
\text { linguistic backgrounds. }\end{array}$ & 6 & & & & & & 15 \\
\hline $\begin{array}{l}\text { 3.4 Effectively communicate resuls of } \\
\text { assessncents to specific individuals } \\
\text { (students, parents, caregivers, collesgues, } \\
\text { administrators, policymakers, poliky } \\
\text { officlals, owmunity, etc). }\end{array}$ & 6 & & & & & & 15 \\
\hline
\end{tabular}


STANDARD 4:

Creating a Literate Environment

\begin{tabular}{|c|c|c|c|c|c|c|c|}
\hline Element & HRRI & HRR2 & HRR3 & PRD & NRPR & TMPR4 & WR53 \\
\hline $\begin{array}{l}\text { 4.1 lke gudenes' interess, reading abilities } \\
\text { and backgrounds as foundations for the } \\
\text { reading and wring program. }\end{array}$ & 16,24 & $17,32,34$ & $6,7,43$ & & & $\begin{array}{c}7,30,31,44,45, \\
46\end{array}$ & 2 \\
\hline $\begin{array}{l}\text { 4.2 Use a large supply of books, } \\
\text { technology-based information, and } \\
\text { nonprint materials representing multiple } \\
\text { kweks, broad interests, and cultural and } \\
\text { linguistic backgrounds. }\end{array}$ & & & 22,23 & & & & \\
\hline \multicolumn{8}{|l|}{$\begin{array}{l}\text { 4.3. Model reading and writing } \\
\text { enthusiastically as zalued lifelong actwities. }\end{array}$} \\
\hline 4.4 Motivate kamers to be lifelong readers. & & & 24 & & & $3,4,47$ & 9 \\
\hline
\end{tabular}


STANDARD 5;

Professional Development

\begin{tabular}{|c|c|c|c|c|c|c|c|}
\hline Element & HRRI & HRR2 & HRR3 & $\mathrm{PRD}$ & NRPR & TMPR4 & WRS3 \\
\hline $\begin{array}{l}5.1 \text { Display postive dispostions related to } \\
\text { reading and the teucting of reading }\end{array}$ & & & & & & & \\
\hline $\begin{array}{l}5.2 \text { Continue to pursue the dewelopment of } \\
\text { professional knowkdge and dispositions. }\end{array}$ & & & $6,37,38$ & & 4,5 & & \\
\hline $\begin{array}{l}5.3 \text { Work with colleagues to observe, } \\
\text { evaluate, and provide fordbaxk on each } \\
\text { other's praxtike. }\end{array}$ & & 32 & & & & & \\
\hline $\begin{array}{l}5.4 \text { Participate in, initiate, implement, and } \\
\text { evaluate professional derelopenent } \\
\text { programs. }\end{array}$ & & & & 9 & 4,5 & & \\
\hline
\end{tabular}




\section{References}

Barr, R., Kamil, M.L., Mosenthal, P., \& Pearson, P.D. (Eds.). (1991). Handbook of reading research (Vol. 2). White Plains, NY: Longman.

Elliott, E. (Ed.). (2003). Assessing education candidate performance: A look at changing practices. Washington, DC: National Council for Accreditation of Teacher Education. Farstrup, A.E., \& Samuels, S.J. (Eds.). (2002). What research has to say about reading instruction (3rd ed.). Newark, DE: International Reading Association.

Kamil, M.L., Mosenthal, P.B., Pearson, P.D., \& Barr, R. (Eds.). (2000). Handbook of reading research (Vol. 3). Mahwah, NJ: Erlbaum.

National Institute of Child Health and Human Development. (2000). Report of the National Reading Panel. Teaching children to read: An evidence-based assessment of the scientific research literature on reading and its implications for reading instruction (NIH Publication No. 00-4769). Washington, DC: U.S. Government Printing Office.

Pearson, P.D. (Ed.). (1984). Handbook of reading research. New York: Longman. Ruddell, R.B., Ruddell, M.R., \& Singer, H. (1994). Theoretical models and processes of reading (4th ed.). Newark, DE: International Reading Association.

Singer, H., \& Ruddell, R.B. (1976). Theoretical models and processes of reading (2nd ed.). Newark, DE: International Reading Association.

Singer, H., \& Ruddell, R.B. (1985). Theoretical models and processes of reading (3rd ed.). Newark, DE: International Reading Association.

Snow, C.E., Burns, M.S., \& Griffin, P. (1998). Preventing reading difficulties in young children. Washington, DC: National Academy Press. 


\section{Appendix E \\ Directions for Panel of Experts}

Purpose: The purpose of a survey review by a panel of experts is to increase the validity of the study survey instrument. Validity is defined as the degree to which a test measures what it is intended to measure (i.e., items relate to the topic, mutually exclusive questions/statements).

\section{Study Research Questions:}

1) Do the reading-instructional-leadership practices of principals differ in Reading First Schools versus Non-Reading First Schools?

2) Does the reading-instructional-leadership professional development of principals differ in Reading First Schools versus Non-Reading First Schools?

3) Is there a difference in Reading/Language Arts WESTEST scores of third grade students in Reading First versus Non-Reading First Schools?

Directions: Review Section 1-5 of Survey of Selected K-5 Public Elementary Principals in West Virginia: Reading Instructional Leadership (attached) and record feedback pertaining to each corresponding item as indicated on this form. Relate each survey question or statement to the following 3 questions for consideration:

1. Does the question or statement adequately address the study research question as guided by the question? The survey is attached.

2. Does the question or statement contain the necessary information to enable an adequate response by the participant?

3. Is the question or statement biased or worded to encourage a particular response?

To simplify the process, use track changes" in Microsoft Word which can be activated by clicking the review tab and then the track changes tab. Record your comments within each survey section based on the 3 questions for consideration. Your input is valuable in improving the survey instrument.

Thank you for taking the time to review this survey instrument. Your input is appreciated. 


\author{
Appendix F \\ Notification Letter to Superintendent
}

March 15, 2010

Dear Ms. Superintendent:

As a partial fulfillment of the leadership studies doctoral program at West Virginia University, I am required to conduct a research-based study focused on improving educational leadership practice. The purpose of my study is to determine if there is a connection between principal professional development and student achievement. The benefit will include valuable information for those who prepare programs for educational leaders. In addition, it will help counties identify best practices as they relate to principal training in order to improve reading and increase student achievement.

Therefore, I am writing to inform you that I will be contacting your K-5 elementary principals and requesting their participation in an electronic survey. Although strongly encouraged, participation is voluntary and there are no consequences for non-participation. All survey responses will be kept confidential and all individual identifying information will be reviewed only by the researcher.

Please encourage your principals to participate in this important study. If you have further questions contact me at rjlewis@access.k12.wv.us or (304)822-3528. Thank you for your assistance this matter.

Sincerely,

Mrs. Robin Lewis

Doctoral Candidate

Department of Educational Leadership

Dr. Helen Hazi

Committee Chairperson

Educational Leadership

West Virginia University 


\section{Appendix G}

Pilot Letter

March 15, 2010

Dear Fellow Educator:

Because of your expertise and experience in the field of reading you have been chosen to participate in a pilot study that will consider the reading instructional leadership practices of K-5 public elementary principals in West Virginia. I am a doctoral candidate at West Virginia University, Morgantown. I am required to conduct a research-based study focused on improving educational leadership practice.

The purpose of my study is to determine if there is a connection between principal professional development and student achievement. The benefit will include valuable information for both principals and those who prepare programs for educational leaders. In addition, it will help you to identify best practices as they relate to your choice in continuing education, ultimately, to improve reading and increase student achievement.

I sincerely appreciate your consideration regarding participation in this study. If you have further questions contact me at rjlewis@access.k12.wv.us or (304) 822-3528. Thank you for your time and interest.

Sincerely,

Mrs. Robin Lewis

Doctoral Candidate

Department of Educational Leadership

Dr. Helen Hazi

Committee Chairperson

Educational Leadership

West Virginia University 


\section{Appendix $\mathrm{H}$}

\section{Panel of Experts - Survey Questions}

Three questions will be posed for the panel's consideration regarding the survey: (Web Center for Social Research, 2006), 1) Do the questions and statements adequately address the study research questions (as guided by a comprehensive review of the literature? 2) Do the questions and statements contain the necessary information to enable an adequate response by the respondent? 3) Is each question or statement biased or worded to encourage a particular response? 4) Should any item be added or deleted? As indicated on the Directions and Review Instrument for the Panel of Experts (Appendix D), these questions are central to each item included on the survey. The panel will provide written feedback utilizing Microsoft Word's track changes within a one week period of time. 
Appendix I

West Virginia Original Reading First Counties

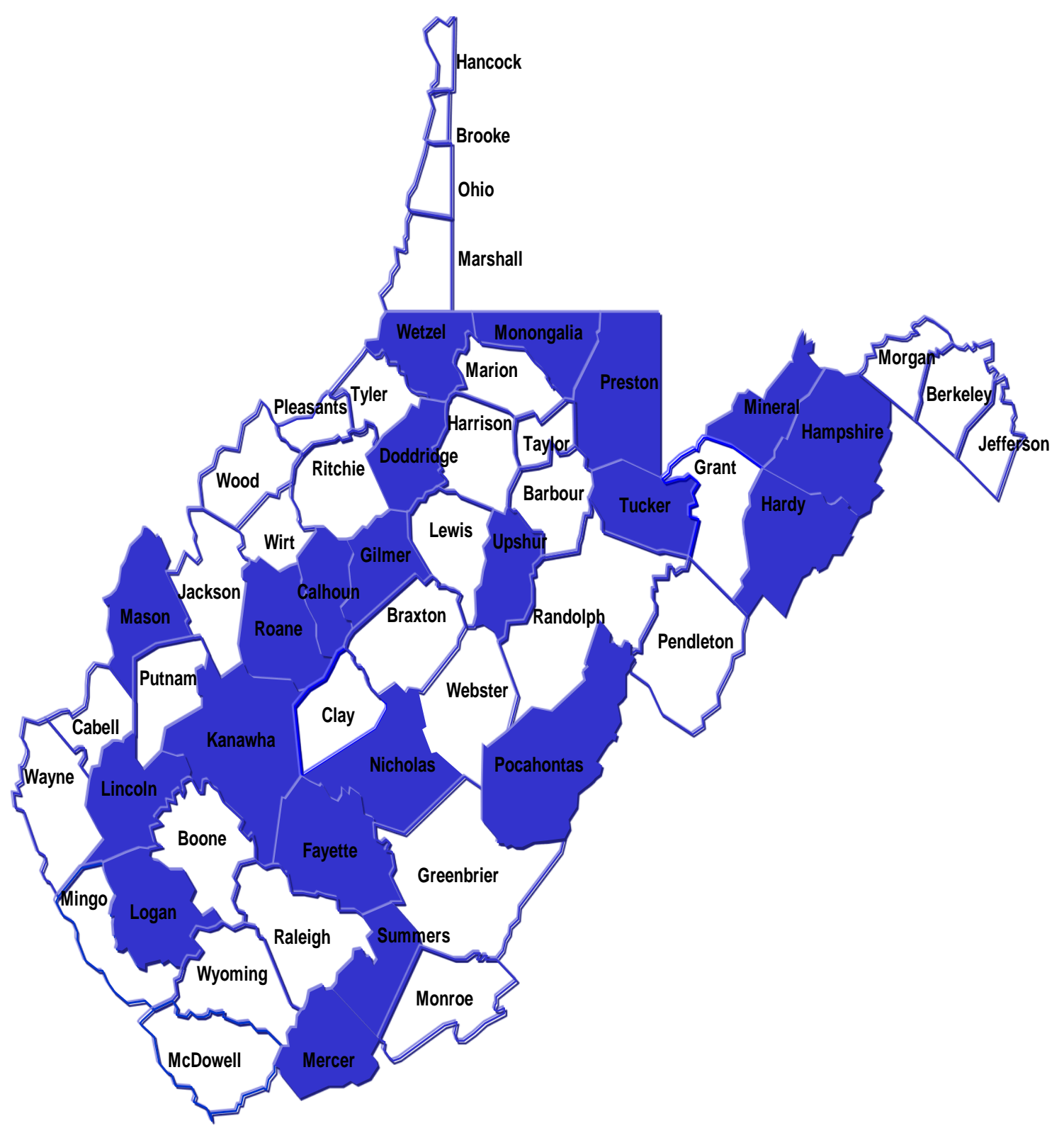




\section{Appendix J \\ Time Line for Survey Response}

Gay (2006) recommended providing two to three weeks for data completion. This allows adequate time for participants to respond to the survey. The following is the timeline (outlined in Appendix J) to be used in data collection. In a one-week period following the superintendents ${ }^{6}$ notice, the dissemination and collection process is initiated. In an effort to maximize the response rate, the sample of 353 principals will be invited up to a maximum of three times to participate in the study using the automatic email feature of Survey Monkey. First, the principals will receive an invitational email directing potential participants to the web-based survey via the URL. A reminder email will be sent requesting participation in the electronic survey. In the third week, if the principal has not responded, a final reminder email will be sent.

Week One: Email will be sent to participants inviting participation in doctoral research study, electronic survey URL included in email. Upon submission, respondents will receive a coupon for refreshment at Sheetz.

Week Two: a reminder email to remaining non-respondents.

Week Three: a final email reminder. Davis (2009) states the growth of internet usage and web based communication increases research methods that provide greater flexibility in data collection. Electronic surveys have removed many restrictions from researchers and increased flexibility regarding when and where subjects may participate (Bonham, 2000). Many researchers have found advantages to the utilization of electronic surveys and web-based surveys which categorize and store data electronically to be used conveniently for later analysis (Lazar \& Preece, 1999). The cost and time is an advantage in using electronic surveys. 
The three most common reasons for selecting electronic surveys over a pencil-paper approach are: decreased costs, faster response rates, and increased response rates (Lazar \& Preece, 1999; Operman, 1995; Saris, 1991). Research is beginning to confirm that electronic surveys provide strong advantages of speedy distribution and response cycles (Swoboda, Muehlberger, Weitunat, \& Schneeweiss, 1997; Yun \& Trumbo, 2000). As use of web-based surveys increases, issues regarding utilization must be considered: security, access, privacy, and ethical issues must be considered (Lazar \& Preece, 1999, Schmidt, 1997). Each of these areas will be address during the development of survey using Survey Monkey. For example, each participant will receive an access code which solely allows only the respondent and the researcher access to the responses. 


\section{Appendix K \\ Mary Lee Porter, Ed.D. \\ 79 Cedar Lane \\ Wheeling, WV 26003 \\ October 25, 2009}

\section{Mrs. Robin Lewis, Superintendent of Schools \\ Hampshire County Schools \\ 111 School Street \\ Romney, West Virginia 26757 \\ (304) 822-3528}

Dear Robin:

Please feel free to use my dissertation, survey, and any other information in any way that you choose that will help you conduct your research and complete your own dissertation. I am happy to help and honored that you have chosen to consider my research. I wish you the best in this important and difficult endeavor.

Sincerely,

$\eta \quad \sim$ ter

Mary Lee Porter 
Appendix L

Panel of Experts Feedback

\begin{tabular}{|c|c|c|}
\hline Panel Member & Positive Comments & $\begin{array}{l}\text { Feedback / } \\
\text { Response to Feedback }\end{array}$ \\
\hline $\begin{array}{l}\text { Beverly Kingery } \\
\text { State Expert }\end{array}$ & $\begin{array}{l}\text { Principal As A } \\
\text { Research Provider } \\
\text { Section met criteria of } \\
\text { the questions }\end{array}$ & $\begin{array}{l}\text { Feedback- Rewrite \#11 so it is not so } \\
\text { biased towards RF and non-RF. \#14 and } \\
\# 15 \text { is the same. } \\
\text { Response- left \#1, but made a stronger } \\
\text { statement regarding opportunity for other } \\
\text { principals. Corrected \#14 and \#15. } \\
\text { Feedback- Typo \#6 should be \#26. } \\
\# 1,4,5 \text { are biased. } \\
\text { Response- corrected typo. Did not } \\
\text { change \#1, 4, and } 5 \text {. }\end{array}$ \\
\hline $\begin{array}{l}\text { Phyllis Veith } \\
\text { State Expert }\end{array}$ & $\begin{array}{l}\text { The survey clearly } \\
\text { reflects the goals of } \\
\text { Reading First Schools. } \\
\text { The survey is very } \\
\text { thorough and includes } \\
\text { the right questions. }\end{array}$ & $\begin{array}{l}\text { Feedback- double check spacing } \\
\text { throughout document and make sure it is } \\
\text { the same throughout. } \\
\text { Response- document spacing was } \\
\text { corrected. }\end{array}$ \\
\hline $\begin{array}{l}\text { Cathy Thompson } \\
\text { State Expert }\end{array}$ & $\begin{array}{l}\text { The survey is well } \\
\text { aligned with the areas } \\
\text { of assessment. }\end{array}$ & $\begin{array}{l}\text { Feedback- make sure that you are } \\
\text { providing proof for you analysis of data. } \\
\text { Response- The following amendment } \\
\text { was made based on recommendation. } \\
\text { Provided statements to show support to } \\
\text { analysis. }\end{array}$ \\
\hline
\end{tabular}

